\title{
CAMERA, CANVAS, AND QIBLA: LATE OTTOMAN MOBILITIES AND THE FATIH MOSQUE PAINTING
}

As with many cultures around the globe, in the nineteenth century the Ottoman empire witnessed a fluidity of media, styles, objects, technologies, and themes in visual culture. Sultans' portraits migrated across canvases, ivory, manuscripts, photographs, prints, and porcelain; curtain motifs featured in tents, wall paintings, and architectural decorations; new and "neo" architectural styles spread via world expositions and cityscapes; depictions of buildings and landscapes reconfigured wall paintings, tombstones, ceramics, textiles, and cutout paper $\left(k \bar{a} a t^{c} \iota\right)$ works. ${ }^{1}$ The long tradition of depicting the Islamic holy cities also responded to these artistic and cultural changes, and images energetically circulated across different regions in shorter periods of time. ${ }^{2}$ Even though Mecca and Medina are physical places, their depictions-and by extension, the holy cities themselves-effectively traveled to far-flung audiences.

Over the last two decades, a number of studies have focused on different periods and aspects of mobility, as well as portability and translation, in art and architecture. ${ }^{3}$ As Mimi Sheller and John Urry emphasize in their research on "new mobilities," information, images, and materials are currently moving at a greater intensity and speed than ever before. ${ }^{4}$ What is distinctive about the study of Haramayn (lit., "two sanctuaries," i.e., Mecca and Medina) images in the nineteenth-century Ottoman context is that it is possible to pinpoint actors more precisely, trace clearer paths of circulation, and determine the speed and magnitude of movement more accurately than with materials from earlier periods. Directly linked to the movement of images, objects, people, and places were imperial statecrafts and modernization processes involving geographic science, infrastructure, printing technologies, and photography.
From the inception of photography in 1839 until today, artists' appreciation of and involvement with the medium have varied greatly. Some artists have discredited the use of photography, whereas others have acknowledged its agency and embraced its application in creative processes. ${ }^{5}$ In the nineteenth century, many artists had access to reservoirs of photographs, such as reproductions of artworks, photographs taken by artists or by their families and friends, and commercially acquired images. ${ }^{6}$ They utilized photographs as study aids and translated photographic models into drawings and paintings via quadrillage, projection, and photo-peinture. ${ }^{7}$ Such analogical transformations are not "direct and complete" reproductions of photographs; rather, "they tend to be diffuse and multifaceted." 8

As David Roxburgh has demonstrated in the context of Qajar art, "remediation," "cross-medium interaction," and "selective appropriation and adaptation" thrived in the fields of photography, lithography, lacquer, and painting. ${ }^{9}$ Image-making processes were no different in the late Ottoman empire. Concerning photography in the Hamidian era (i.e., under Sultan 'Abdülhamid, r. 1876-19o9), Ahmet Ersoy has pointed out that the "mobility" and "mutability" of photographs enabled "multiple visual, textual, and material encounters," from paintings to illustrated journals. ${ }^{10}$ In their scholarship, both Roxburgh and Ersoy draw on sources from media studies to examine nineteenth-century Qajar and Ottoman visual culture. ${ }^{11}$ These are helpful interdisciplinary tracks for studying this period and what comes after. ${ }^{12}$ Nevertheless, such approaches require a great deal of caution when applied to works from earlier periods, as they build upon the immediacy created by linear perspective in Renaissance art. ${ }^{13}$

(C) SABİHA GÖLOĞLU, 2021 | DOI:10.1163/22118993-00381P09

This is an open access article distributed under the terms of the CC BY 4.o license. 
Several other scholars have also highlighted Ottoman artists' engagement with photography by linking postcards and photographs with wall and canvas paintings. ${ }^{14}$ Moreover, photographs of the Islamic holy sites were similarly translated into canvas paintings, prints, and even a prayer rug. These cross- and multi-media endeavors present endless possibilities and varying degrees of alterations. ${ }^{15}$ Among artists, the French-Algerian painter Étienne (Nasreddine) Dinet (d. 1929) and the Ottoman painters Mahmud, Kolağası (Hoca) 'Ali Rıza (d. 1930), and Mi'marzade Muhammed 'Ali (d. 1938) painted the Haramayn after photographs or prints. ${ }^{16} \mathrm{Im}$ ages of Mecca and Medina were also at the service of pilgrims and writers. For instance, the Ottoman bureaucrat Hüseyin Vassaf (d. 1929) used a variety of photographs, postcards, maps, and prints from local and foreign newspapers and books in two surviving manuscript copies of his travelogue, Hicāz Hātırası (Memoir of the Hijaz, 1906 and 1925), which was published only a decade ago. ${ }^{17}$

It is possible to trace the visual sources used in these works because only a handful of photographers are known to have photographed Mecca and Medina in the second half of the nineteenth century. Even though there are photographs whose authorship remains unknown or debated, the following are the four main actors responsible for the production and dissemination of early photographs of the Haramayn from the 186os onward: 1. the Dutch scholar Christiaan Snouck Hurgronje (d. 1936); 2. the Meccan doctor al-Sayyid 'Abd alGhaffar (d. unknown); 3. the Ottoman-Egyptian army officer Muhammad Sadiq Bey (d. 1902); and 4. at least one other photographer from the Ottoman committee of the Erkān-ı Harbiyye (General Military Staff). Two major collections in the Istanbul University and Leiden University Libraries contain substantial amounts of photographs from these four parties, together with maps and archival documents. ${ }^{18}$

Even though there are studies on single photography collections, no thorough comparative study has been undertaken on the Haramayn photographs in the Ylldız Albums of the Istanbul University Library (IÜK), those in the books of Snouck Hurgronje, and those in the Leiden University Libraries. ${ }^{19}$ A number of voluminous prestige tomes, as well as more accessible books on photographs of Mecca and Medina, have appeared within the last two decades; most of these works do not extend beyond the catalogue format, however. ${ }^{20}$ Badr El-Hage, Carney E. S. Gavin, Claude W. Sui, Stephen Sheehi, Meraj Nawab Mirza, and Abdullah Saleh Shawoosh have written about the works of the early photographers of the Haramayn and made important contributions to scholarship, ${ }^{21}$ but their studies do not provide a systematic examination of the photographic oeuvres of the aforementioned four parties, which are dispersed in various collections. ${ }^{22}$ Given that for centuries non-Muslims were not allowed to visit the Haramayn, and considering the otherwise unrecorded architectural transformations of both pilgrimage and visitation shrines over time- - especially more radically in recent years - these photographs provide precious information for architectural and religio-cultural historians of the Ottoman era.

Even though the majority of the surviving Haramayn photographs are from the 188 os, it should be remembered that from 1839 onward Egypt, Palestine, and Syria had attracted European photographers searching for biblical and historical references. ${ }^{23}$ Many photographers—such as Jakob August Lorent (d. 1884), Auguste Salzmann (d. 1872), James Robertson (d. 1888), Felice Beato (d. 1909), and Félix Bonfils (d. 1885)—captured the holy sites in Jerusalem during these early decades of photography. ${ }^{24}$ With the development of the wetcollodion method and glass negatives, photography became widespread in these regions, and photographic studios proliferated in cosmopolitan centers such as Beirut, Cairo, Damascus, Istanbul, and Jerusalem. ${ }^{25}$ Such studios and their photographers served locals and European tourists alike, as well as the Egyptian khedives and Ottoman sultans. The proliferation of steamships and the opening of the Suez Canal in 1869 made the Red Sea and the southern coast of the Arabian Peninsula more accessible than ever before. Nevertheless, the Haramayn remained an exclusively Muslim sacred domain (i.e., haram, meaning "forbidden, sanctuary"). Since these sites were off-limits to non-Muslims, they saw much less photographic activity until the twentieth century. ${ }^{26}$

The photographs of Medina taken in 1861 and those of the Haramayn taken in the 188 os reached diverse viewers, became inspirations for artists working in different media, and served Dutch and Ottoman ideologies in 
various ways. This study focuses on one particular case: a painting inside Mehmed II's mosque in Istanbul (later called the Fatih Mosque), which invites an exploration of materiality and the lives of objects, ${ }^{27}$ as well as the multiple mobilities of images, photographs, photographers, viewers, and places. ${ }^{28}$ The article begins with a description of the Fatih Mosque painting, including its formal features and visual references that were shaped by the geopolitics and "geopiety" of the Hamidian era. ${ }^{29}$ It continues with an examination of the photographic oeuvres and movements of Snouck Hurgronje, 'Abd alGhaffar, Sadiq Bey, and the anonymous member of the Ottoman committee of the Erkān-ı Harbiyye, as well as this military committee's cartographic activities in the Hijaz province. It then maps the itineraries of photographs from the Hijaz to Istanbul and Leiden, tracing the migration process of images and thus the symbolic dispersal of Islam's two holiest sites across different media. Finally, it discusses how recurring images of Mecca and Medina were affixed to surfaces oriented in the qibla direction to direct and mobilize viewers with the immediacy they created. Even though the visual sources of this painting and its ideological connotations may not have been obvious to many in the contemporary mosque congregation, the placing of Mecca and Medina images in the qibla direction constituted a pious decorum that was widely and carefully followed for centuries.

The aim of this study is to investigate the production and circulation of early Haramayn photographs within the ethnographic, geographic, and technological particularities of the period. I also observe how these photographs were translated into various media and objects with different functions, including their use in the spatial tradition of qibla decorum outlined above. The present study communicates the limits, lives, possibilities, and uses of photographic views and the exchanges between photography, painting, and print media. It decenters the history of photographic production in the Ottoman empire by shifting the focus from political centers and photographic studios to more remote locations and lesser-known photographers. Moreover, it emphasizes the effective role of print media in disseminating and mobilizing the photographic image and the malleable politics of representation, especially with regard to the two sacred cities of Mecca and Medina.

\section{THE FATIH MOSQUE PAINTING}

The oil-on-canvas painting now located in the Fatih Mosque attests to transregional contacts across Western Europe and the Ottoman empire, as well as the remediation of photographic images in various formats (fig. 1). ${ }^{30}$ Although its original provenance remains unknown, the painting is currently hanging on the pillar adjacent to the muezzin's loge towards the qibla direction, emphasizing and enhancing viewers' orientation during prayer (fig. 2) ${ }^{31}$ It merges views of the planets, the globe, the Hijaz Railway, the Great Mosque in Mecca (al-Masjid al-Haram), Medina, Istanbul, the Hamidiyye Mosque outside the Yildız Palace in Istanbul (commissioned by 'Abdülhamid II), and a pavilion with "Moorish" details typical of neo-Ottoman architecture. ${ }^{32}$ The painting also incorporates a Qur'anic inscription from Sürat al-Shūrā (42:19) - "God is most subtle to His creatures"-above the Medina image. ${ }^{33}$ Furthermore, the images of the Ka'ba and the Green Dome of the Prophet's Mosque in Medina (al-Masjid al-Nabawi) reappear in a small scale above the upper curve of the Earth between the two holy cities.

The Fatih Mosque painting bears the signature of Mi'marzade Muhammed 'Ali, mentions his position as a scribe in the Secretarial Office of the Shaykh al-Islam, and gives the date 27 Ramadan 1323 (November 25, 1905) in a red inscription in naskh and tacliq scripts in the lower left corner of the canvas ( $f \grave{\imath} 27$ Ramażānü'lMübārek sene 1323, Meşīhat-ı 'Ulyā Mektūbì Kalemi Hulefāsından Mi'mārzāde Muhammed 'Alī). ${ }^{34}$ At least five lines of another $t a c^{c} \bar{q} q$ inscription above the red one are not legible, as they have been covered with a thick layer of paint. ${ }^{35}$ Mi'marzade Muhammed 'Ali (d. 1938) was not only a scribe but also held an architecture degree from the Istanbul Academy of Fine Arts (Șanāyi $i$ Nefise Mektebi), as indicated by the word "architect" (mi'mār) in his titulature. ${ }^{36}$ His works suggest that he was a versatile painter, illuminator, and calligrapher. ${ }^{37}$ Between 1919 and 1922, he served as the director of the Museum of Pious Foundations (Evkâaf-ı İslāmiyye Müzesi), but then, due to political conflicts with the new secular Republican government of Turkey, he was forced to flee to Cairo with his father-in-law Mustafa Sabri Efendi, a former shaykh al-Islam. ${ }^{38}$

Earlier canvas paintings of Mecca are preserved in the Bursa Great Mosque and the Uppsala University Library 


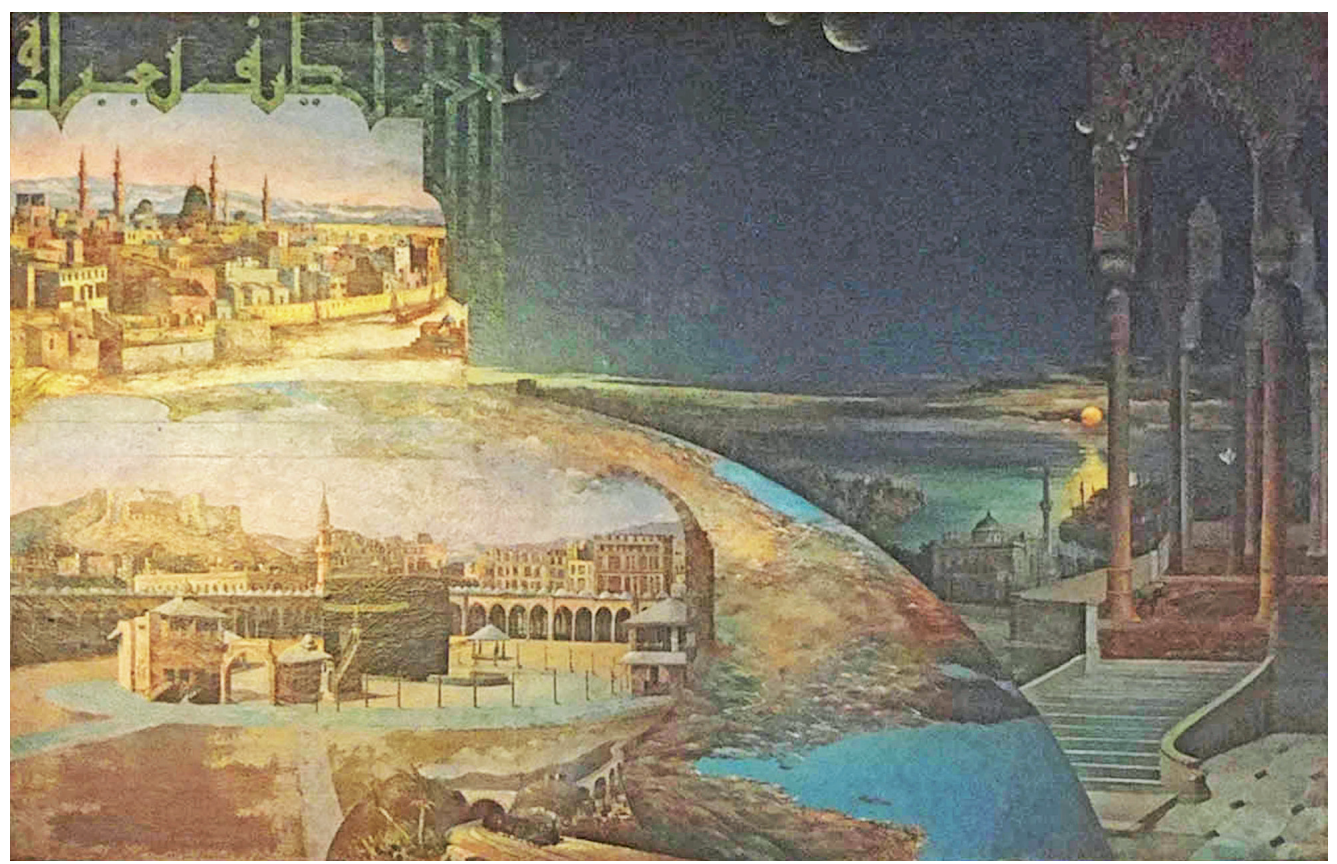

Fig. 1. Mecca, Medina, and Istanbul. Mi'marzade Muhammed 'Ali, 27 Ramadan 1323 (November 25, 1905), oil on canvas, $130.4 \times 195.4 \mathrm{~cm}$. Istanbul, Fatih Mosque. (Photo: Sabiha Göloğlu, with the permission of Fatih and İstanbul Müftülüğü)

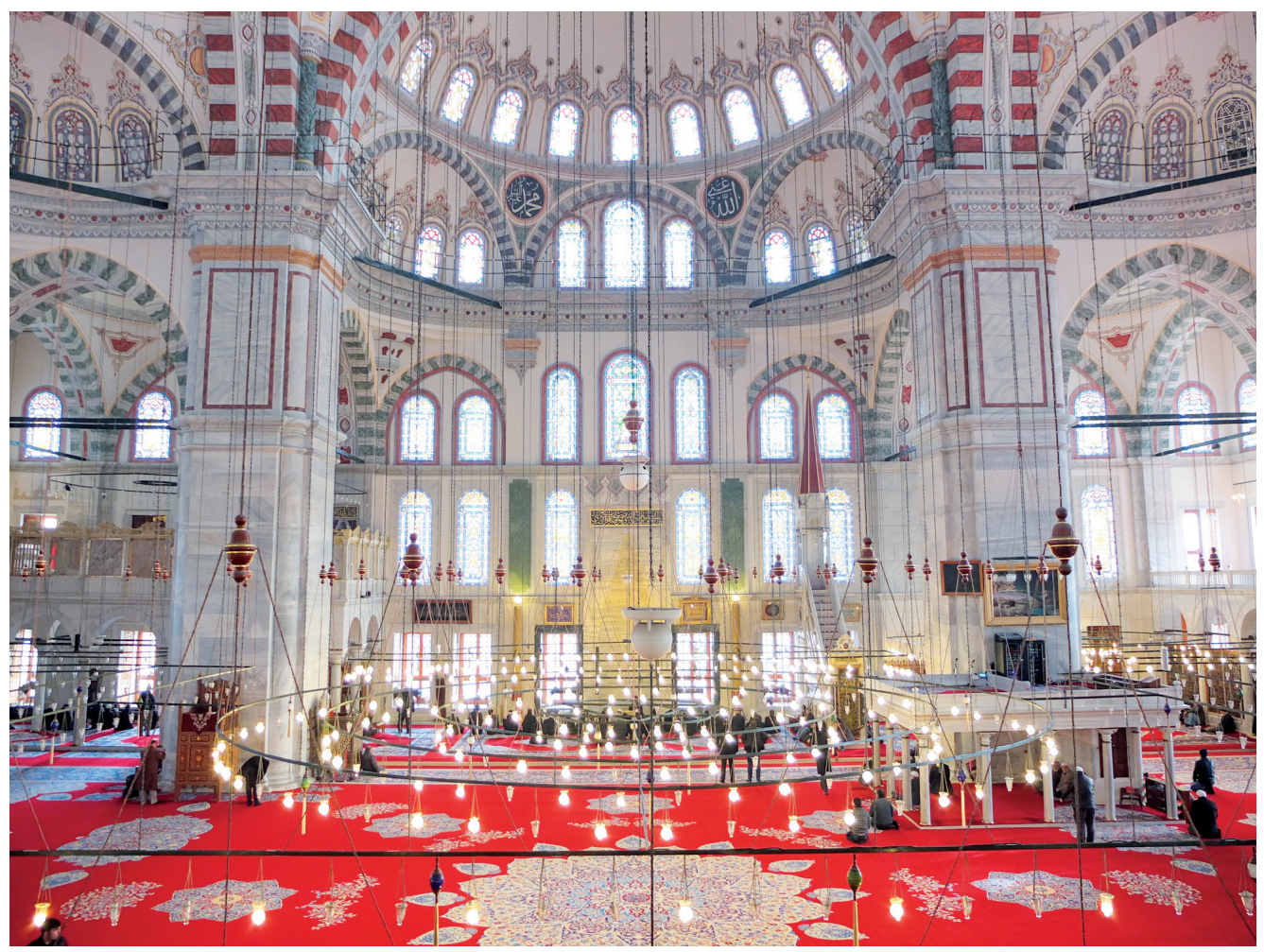

Fig. 2. Interior view of the Fatih Mosque, Istanbul. (Photo: Sabiha Göloğlu, with the permission of Fatih and İstanbul Müftülüğ̈̈) 
(1710-12). ${ }^{39}$ What is intriguing about the composition of the Fatih Mosque painting is its collage of photography, painting, and print media. ${ }^{40}$ According to İbnülemin Mahmud Kemal İnal, Mi`marzade defined his calligraphic style as "mixed with painting" (resimle $m e m z \bar{u} c) .{ }^{41}$ Similarly, it is possible to describe Mi'marzade's painting style as being "mixed with photographs and prints." Three pictorial sources that Micmarzade used in his Fatih Mosque painting can be securely traced. Those for the Masjid al-Haram and Medina views can be directly or indirectly traced back to photographs by 'Abd al-Ghaffar and the Ottoman military committee (either by Sadiq Bey or another member), as will be demonstrated subsequently. The Yıldız Hamidiyye Mosque view can also be linked to an original source, which leads to several copies of a photograph preserved in the Yildız Albums at the Istanbul University Library (figs. 3-4). Mi'marzade must have used a copy or a reproduction of figure 4 for his study of the mosque. ${ }^{42}$ After extracting the Ylldız Mosque from its original background, the painter reworked the photographic image in oil so as to include Sarayburnu (Seraglio Point) on the right-hand side of the mosque and Üsküdar on the left. He also painted the Golden Horn and the Bosphorus on both sides, which merge behind the mosque towards the Sea of Marmara under the full moon.

Completed in 1886, the Ylldı Mosque was built in a neo-Ottoman style with Gothic and Orientalizing "Moorish" elements, similar to the Alhambra-like pavilion shown on the right-hand side of the Fatih Mosque painting. ${ }^{43}$ Ahmet Ersoy describes this and other historicist interests of the 'Abdülhamid period as "Ottoman Romantic medievalism," which aimed at creating a second Ottoman architectural renaissance. ${ }^{44}$ The late Tanzimat revivalist paths that looked back to Nasrid Spain were paved by the growing number of richly illustrated publications and were prominently realized in the interior decoration of the Beylerbeyi (1865) and Çırağan (1871) palaces. ${ }^{45}$ Indeed, the imposing pavilion on the left side of the Fatih Mosque painting displays columns, column capitals, and arches that strongly resemble those of the arcaded Court of the Lions in the Alhambra Palace in Granada. The revival of the medieval angular Kufic script in calligraphy is another feature of this romanticizing artistic milieu; Mi`marzade also practiced the Kufic script in the fourteenth-century

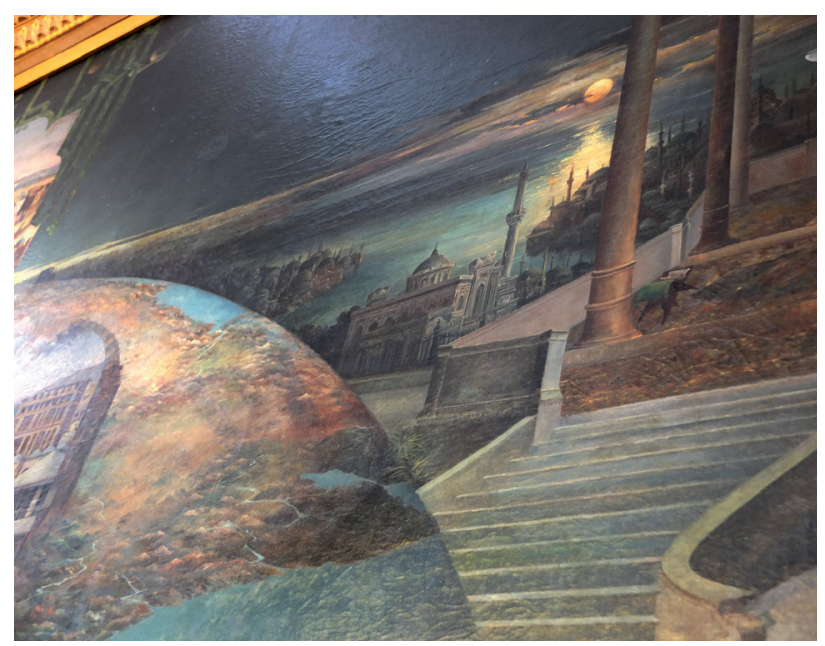

Fig. 3. Detail showing Istanbul. Mi'marzade Muhammed 'Ali, 27 Ramadan 1323 (November 25, 1905), oil on canvas, $130.4 \times$ 195.4 cm. Istanbul, Fatih Mosque. (Photo: Sabiha Göloğlu, with the permission of Fatih and İstanbul Müftülüğü)

Yıldırım Bayezid Mosque in Bolu and in the upper left corner of the Fatih Mosque painting. ${ }^{46}$

Mi'marzade depicted another significant project of 'Abdülhamid II in this painting: the Hijaz Railway (1900-1908), which animates the otherwise still cityscapes. On the lower right corner of the Mecca image, a train proceeds through a landscape with hills, palm trees, a viaduct, a tunnel, and a cluster of buildings. The Hijaz Railway was built to connect Damascus and Mecca in order to shorten pilgrims' travel, while also consolidating caliphal authority and reasserting the empire's territorial claims. ${ }^{47}$ Even though the railway never reached Mecca (as claimed in the painting), the segment to Medina was inaugurated in 1908. Similar to the construction of other railway lines, this grand project was frequently publicized in the press with pan-Islamic sentiments and construction photographs of its stations, tracks, tunnels, bridges, and viaducts. ${ }^{48}$ The modernizing projects of infrastructure were celebrated with depictions of bridges, trams, trains, and steamships in late Ottoman wall paintings, which were based on such prints as well as photographs and postcards. ${ }^{49}$

The Ylldız Hamidiyye Mosque and the Hijaz Railway-two royal commissions pertinent to Istanbul and the Haramayn - were also represented in sculptural and relief forms in the telegraph monument of Damascus 


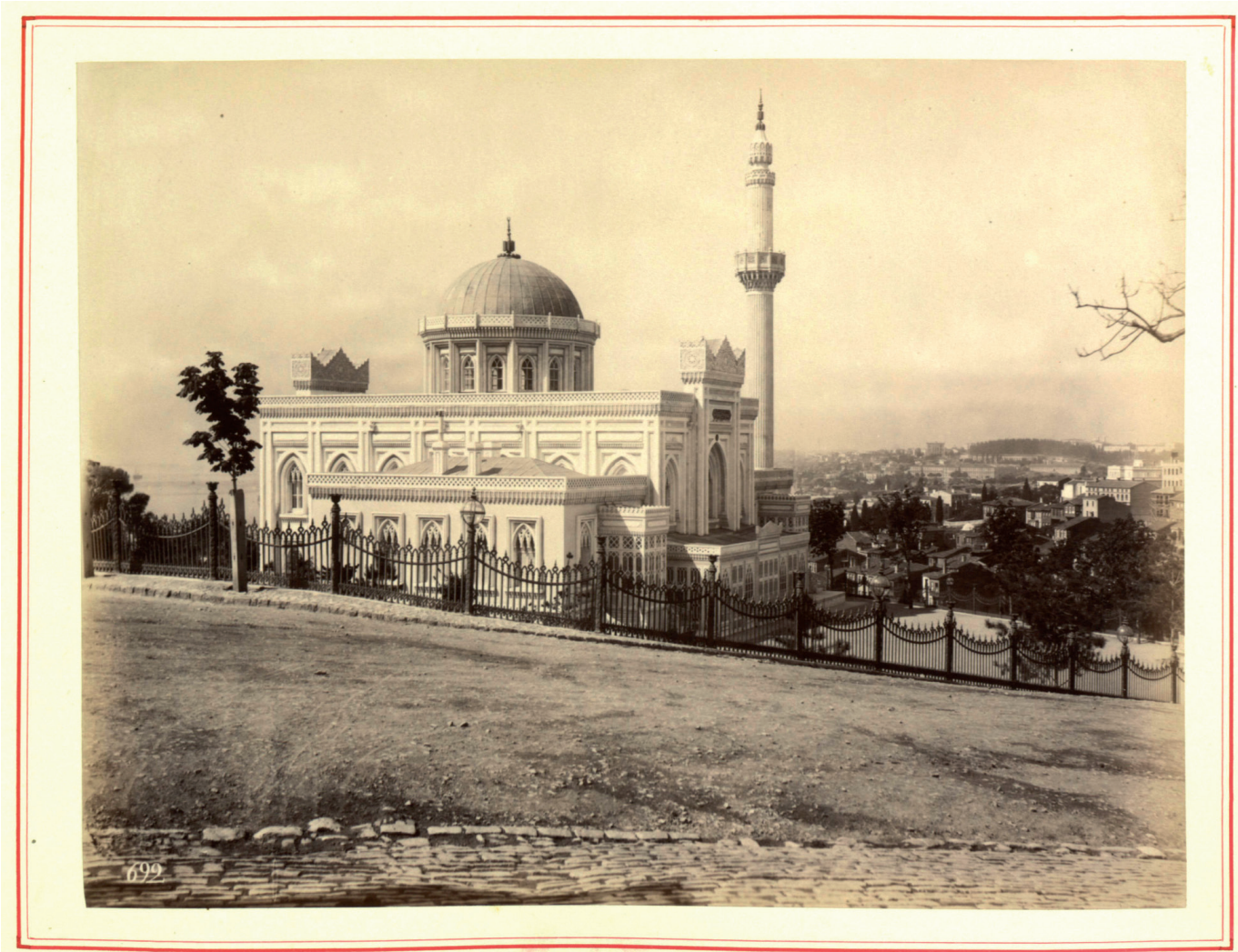

Fig. 4. Ylldız Hamidiyye Mosque. Istanbul University Library, Rare Works Collection, no. 90836/12. (İstanbul Üniversitesi Kütüphanesi)

in 1907-8 and in the railway monument of Haifa in 1901-2. ${ }^{50}$ These monuments helped to spread the pious and modern image of 'Abdülhamid II beyond the Ottoman capital. As David Simonowitz has argued, "the sultan sent an image or rather a miniature of an Ottoman imperial space to the holy cities" by means of the mosque wagon of the Hijaz Railway. ${ }^{51}$ Operating along similar tracks but traveling in the opposite direction, depictions of Mecca and Medina transported the Islamic sacred sites to Istanbul and across the globe.

Mi'marzade's positioning of these projects and the cities of Mecca, Medina, and Istanbul on Earth and among the planets was a careful choice that reflected an Ottoman vision of the cosmos. During the reign of 'Abdülhamid II, geography became part of the curricula at various levels in military and civil schools, whether the subject was framed as European, Ottoman, or Islamic. ${ }^{52}$ The Hamidian regime recognized and explored the didactic possibilities of wall maps and maps in geo- graphy textbooks and atlases to emphasize the unity of the Ottoman lands despite shrinking territories on three continents..$^{53}$ There is not much information about the prevalence and use of three-dimensional globes; however, photographic documentation attests to their existence in the imperial library at the Ylldız Palace. ${ }^{54}$ It was this versatile "Hamidian visual archive" - replete with a wide range of media from maps to photographs and prints - that provided an abundance of sources and ideas for the press and artists such as Mi'marzade. ${ }^{55}$

Above the architectural, cartographic, and cosmic imagery of the Fatih Mosque painting, Mi'marzade included the aforementioned Qur'anic inscription (42:19) about God's kindness and grace as a textual reminder of the creator of the universe. The painting can thus be understood as a pictorial composition propagating the image of a central Ottoman caliphate in Istanbul, and the empire's extensive territories reaching all the way to Mecca and Medina (fig. 1). The latter two cities 
immediately stand out as religious centers, while the capital Istanbul is presented as the Ottoman political center. The "Moorish" pavilion, shown with an open Qur'an copy on a wooden stand, and the silhouettes of Sarayburnu and Üsküdar, overpopulated with domes and minarets, further underscore the pious theme of the painting and position Istanbul a religious center as well (fig. 3). ${ }^{56}$ The accumulation of the Prophet Muhammad's relics in Istanbul following the defeat of the Mamluks at the Battle of Ridaniye (1517) further amplified the sanctity of the Ottoman capital. ${ }^{57}$ As defined by the Tanzimat statesman Reşid Pasha (d.1858), the three pillars of the Ottoman state (üç rükn-ü devlet) were "Islam, the sultanate, and the caliphate all of which were sustained by the House of Osman which protected Mecca and Medina and the continuity of Istanbul as the capital of the empire." 58 This Tanzimat view of the Ottoman state was also present in earlier and later periods, such as the Hamidian era, when it was visually crystallized in the Fatih Mosque painting. ${ }^{59}$

\section{MAPPING AND PHOTOGRAPHING THE HIJAZ}

Ottoman cartography was practiced in various forms, including illustrated histories, atlases, portolans, siege maps, and water supply maps. ${ }^{60}$ These maps served specific purposes and ideologies, strengthened territorial claims, and conveyed imperial messages. ${ }^{61}$ When geography was conceptualized and practiced as a science in the nineteenth-century Ottoman empire, the manipulation of such messages became even more planned and systematic. In this context, it is no surprise that the military staff was assigned to produce maps and photographs of the Hijaz that aimed at consolidating and validating Ottoman power in the region with geopious awareness.

The Ottoman-Egyptian army officer, engineer, and cartographer Muhammad Sadiq Bey $\left(183^{2-1902)}\right.$ is known to have taken the first photograph of Medina in 1861. However, his later photographs of Mecca and Medina, which he took as a member of the Ottoman Committee of the Erkān-ı Harbiyye in 1880-81, are the ones that became widespread, first as albumen prints and then in other media. ${ }^{62}$ According to the pamphlets that advertised his photographic portfolio, as well as the stickers and seals used on his photographs in 1881, Sadiq Bey's early photographs of Medina were exhibited in the Egyptian pavilion at the Centennial International Exposition in Philadelphia (1876). ${ }^{63}$ In the first of his four books, Nubdha fi istikshāf țarīq al-arż al-Hijāziyya (A Short Report about Surveys of the Hijaz Route), published in 1877, Sadiq Bey described the photographs he took in Medina with an emphasis on his pioneering role in photography. ${ }^{64}$ The work includes two lithographs showing views of Medina and the Masjid al-Nabawi (signed by H. Ravon) after the photographs taken during this trip (fig. 5), as well as a plan of the Masjid al-Nabawi and a map of routes between Medina, al-Wajh, and Yanbu. On his first visit to Medina in 1861, Sadiq Bey worked on a topographical survey of the pilgrimage routes in the Hijaz and also accompanied Sa id Pasha (r. 1854-63), the governor of Egypt. ${ }^{65}$

During his second visit to the Hijaz (1880-81) as the commander of the Egyptian pilgrimage caravan (șurre emini or amìr al-hajij), Sadiq Bey took photographs of both Mecca and Medina, which were then marketed as photographic portfolios. A photograph of the Kaba taken during this visit was awarded a gold medal at the Third International Geographical Congress and Exhibition in Venice in 1881. ${ }^{66}$ Furthermore, Sadiq Bey's second book, Mash'al al-Mahmal (Torch of the Pilgrimage Palanquin), came out in 1881, shortly after this visit. Here, Sadiq Bey's pilgrimage account was accompanied by two woodcuts of the Masjid al-Nabawi and Medina signed by Francesco Canedi (fig. 6). These were either made after the 1861 photographs of the mosque and the city, or from their lithographic reproductions in Nubdha fi istikshāf țarīq al-arż al-Hijāziyya (fig. 5). Two almost identical lithographs of a mahmal, which show the palanquin on a camel guarded by soldiers and surrounded by a crowd, were used on the front cover and inside the Mash'al al-Mahmal. Sadiq Bey's other books, Kawkab al-Haij (Star of the Hajj) and Dalil al-Hajj (Guide to the Hajj), were published in 1886 and 1896 following his third and fourth visits to the Hijaz in 1884 and 1885 , when Egypt was under the British protectorate. The former work consisted of two plans of the Masjid al-Haram and the Masjid al-Nabawi and a map showing the pilgrimage routes leading to Mecca and Medina; all were made using the lithography technique. The latter book, however, included photomechanically reproduced 


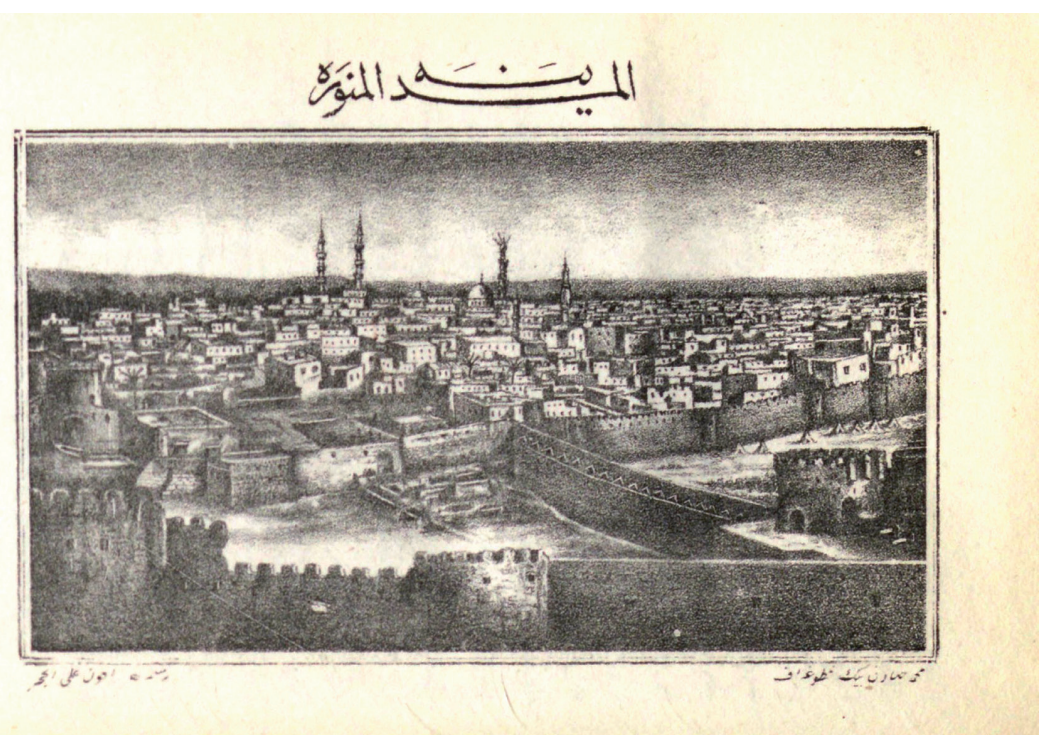

Fig. 5. Al-Madina al-Munawwara. Lithograph, after a photograph by Sadiq Bey, signed by H. Ravon. Sadiq Bey, Nubdha fi istikshāftạīq al-arż al-Hijäziyya, 1294 (1877), 16-17. (Early Arabic Printed Books from the British Library, accessed November 9, 2019, <http://tinyurl.gale.com/tinyurl/CBRzU3>)

photographs of Sadiq Bey, unlike the lithographs and woodcuts of the Masjid al-Nabawi and Medina in his former publications.

Unfortunately, the 1861 photographs of Medina cannot be securely identified among the extant corpus attributed to Sadiq Bey. ${ }^{67}$ Therefore, at this point, the earliest surviving photographs of Mecca and Medina can be dated to $1880-81$, when Sadiq Bey and the rest of the Ottoman military committee conducted a geographical survey in the Hijaz. Meraj Nawab Mirza and Abdullah Saleh Shawoosh point out the concurrent presence of the committee and Sadiq Bey in the Masjid al-Haram during one Friday prayer, based on a pair of photographs. ${ }^{68}$ In Makka Al-Mukarrama and Al-Madina AlMunawwara in Photographs from the Ottoman Period (2013), Sadiq Bey is more specifically recognized as a member of the military committee charged with taking photographs and preparing maps of the Hijaz. ${ }^{69}$ Although Sadiq Bey is well known, the remaining members of the Ottoman military committee are relatively unknown.

The Istanbul University Library has a number of maps (sing. harița) and plans (sing. makțac -i ufkī) produced by the Erkān-ı Harbiyye committee that visualize different parts of the Hijaz by means of surveying (istikşa $\bar{f}$ șūretiyle/ușūlüyle) $\cdot{ }^{70}$ Among them, the maps of Mecca, Medina, Jidda, Yanbu, and Ta'if, as well as plans of the Masjid al-Haram and Masjid al-Nabawi, date between 188o and 1881. However, those of the Hijaz province and the Masjid al-Haram's courtyard date from 1883-84 (fig. 7). ${ }^{71}$ Several of these maps and plans also featured in Sadiq Bey's books published in Cairo. ${ }^{72}$ As Sadiq Bey notes in Mash'al al-Mahmal, he met the photographer Kaymakam 'Ali Bey and five other officers of the Ottoman military committee in Mecca who were in charge of preparing maps of the territory, taking photographs of Mecca and Ta'if, drawing routes leading to Medina, and doing whatever else was necessary for the topographical survey of the Hijaz. ${ }^{73}$ Therefore, this 'Ali Bey, about whom further information is lacking, was likely responsible for several of the Haramayn photographs in the Yildız Albums.

The map of Mecca and the plan of the Masjid al-Haram carry the seal impressions of members of the military committee assigned to the Hijaz in $1880-81 .{ }^{74}$ The city map (1881) contains seal impressions of Binbaşı Seyyid Mehmed Cemal (major), Kaymakam Seyyid Ahmed Cemaleddin (lieutenant colonel), Kaymakam Ahmed Hakkı (lieutenant colonel), and Miralay Hayri (colonel), leaving only one committee member's name 


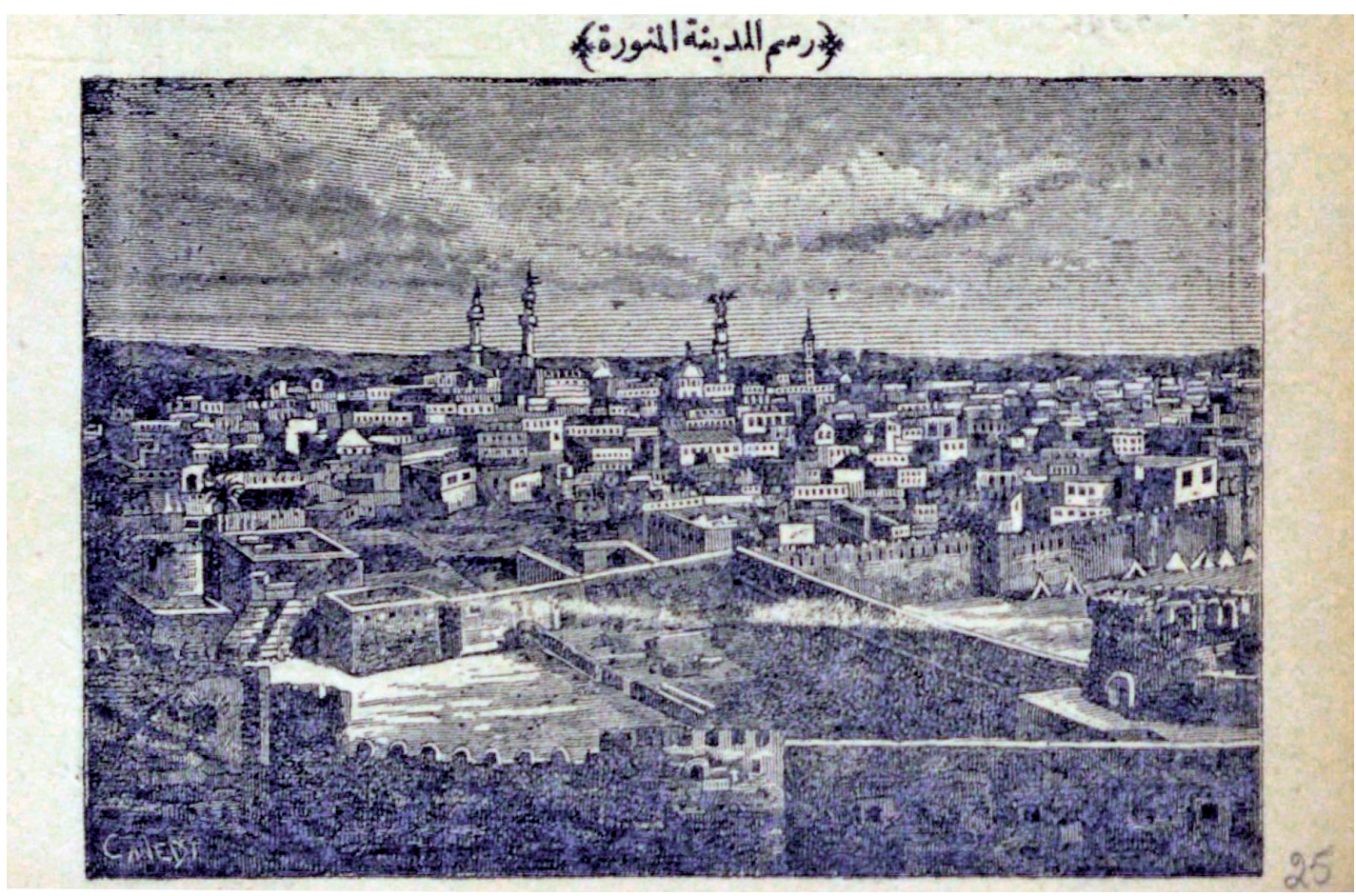

Fig. 6. Rasm al-Madina al-Munawwara. Woodcut, after a photograph by Sadiq Bey and/or H. Ravon's lithograph, $15 \cdot 5 \times 23.8$ cm, $8 \times 11.8$ cm. Sadiq Bey, Mash'al al-Mahmal, 1298 (1881), 45. (Early Arabic Printed Books from the British Library, accessed November 9, 2019, <http://tinyurl.gale.com/tinyurl/CBS47X>)

unknown. In the mosque plan (1881), the seal impression of a certain Binbaşı Seyyid Mehmed Sadık replaces that of Kaymakam Ahmed Hakkı. This can only be the Ottoman-Egyptian photographer and cartographer Sadiq Bey discussed above, now listed among the other members of the Erkân-ı Harbiyye committee.

The plan of the Masjid al-Haram's courtyard, dated to 1883-84 (fig. 7), features only one seal that reads "Seyyid Mehmed Șäık" and an inscription further identifying him as a lieutenant colonel of the General Military Staff and the head engineer of 'Ayn Zubayda, namely the Mecca water supply channel (Kaymakāam-ı Erkān-ı Harb ve 'Ayn-ı Zübeyde Sermühendisi). Unlike the 1881 plan of the Masjid al-Haram, this plan does not show the surroundings of the mosque and the two domes (qubbatayn) that were removed from the courtyard in $1882-83 .{ }^{75}$ Apart from these, two later documents in the Istanbul University Library can be attributed to Sadiq Bey: the 1888 map of Mecca, and the 1887 report (lä̉iha) concerning repairs to the 'Ayn Zubayda, both of which bear the seal impression "Seyyid Mehmed Șādık b. Muștafā."76
Sadiq Bey's name also appears in the Hijaz province yearbooks (Hicāz Vilāyeti Sālnāmesi) of 1884 and 1886 as a military officer of the Erkān-ı Harbiyye and as the head of the building commission, which further attests to his continuous presence and assignment in the Hijaz. ${ }^{77}$ Even though the photographs and maps by Sadiq Bey and the military committee changed contexts over time, the geographical knowledge they produced initially served the imperial endeavors of the Hamidian regime. ${ }^{78}$

\section{TRACKING PHOTOGRAPHERS}

A few Europeans managed to penetrate the Haramayn in the second half of the nineteenth century and published their travelogues upon returning to Europe. ${ }^{79}$ Although their work achieved a certain popularity, none of them pursued ambitious scholarly research or carried a camera except the Dutch scholar Christiaan Snouck Hurgronje (1857-1936). Snouck Hurgronje received his doctoral degree from Leiden University in 188 o, with a 


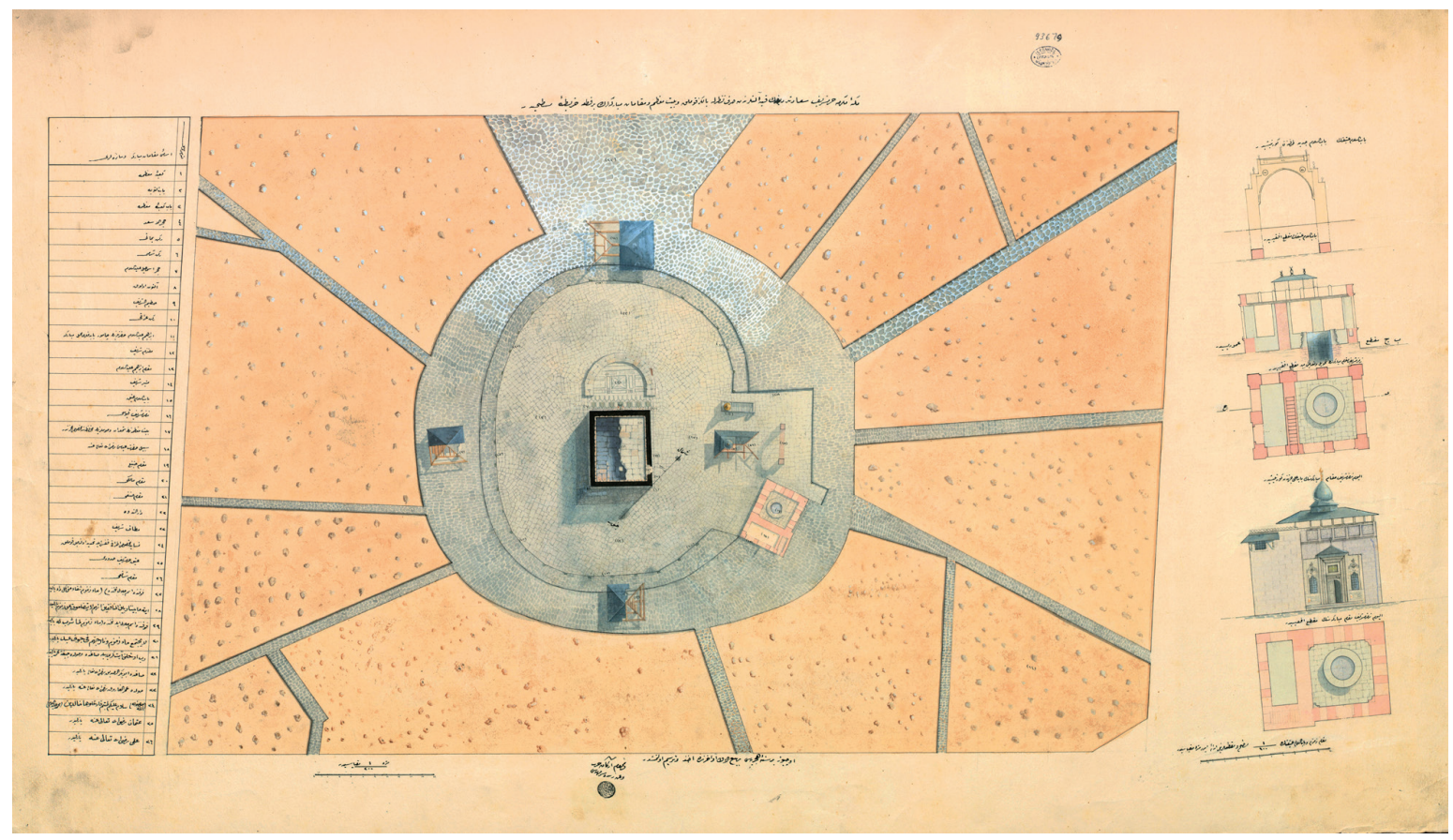

Fig. 7. Courtyard plan of the Masjid al-Haram, 1301 (1883-84), $71 \times 122 \mathrm{~cm}$, scale: 1/200. Istanbul University Library, Rare Works Collection, no. 93679. (İstanbul Üniversitesi Kütüphanesi)

dissertation entitled Het Mekkaansche Feest (The Meccan Festival), in which he described the Muslim rites of pilgrimage and their possible origins. ${ }^{80}$ He traveled to Jidda in August 1884 and stayed at the Dutch Consulate before moving into a house in the Muslim quarter of the city. There he converted to Islam and took the name 'Abd al-Ghaffar (also the name of the Meccan doctor), and then proceeded to Mecca in February $1885 \cdot{ }^{81} \mathrm{He}$ stayed there until he was expelled from the city under accusations of smuggling in July 1885 , before performing the pilgrimage. ${ }^{82}$

Returning to Leiden, Snouck Hurgronje published two volumes on Mecca, accompanied by two portfolios of collotype photographs, as well as chromo- and tinted lithographs. Mekka: Die Stadt und ihre Herren (Mecca: The City and Its Rulers) and Mekka: Aus dem heutigen Leben (Mecca: From Daily Life) were published in 1888 and 1889 , respectively. ${ }^{83}$ The Bilder-Atlas (Picture Atlas) accompanied the first publication in 1888 , whereas Bilder aus Mekka (Pictures from Mecca) was published as a separate portfolio in $1889 .{ }^{84}$ These publications reflect Snouck Hurgronje's interest in religious scholarship and ethnic groups in Mecca, especially those from the Dutch East Indies. His interest was a response to the Dutch colonial enterprise and concerns about the spread of pan-Islamism. ${ }^{85}$ His employment as an advisor on indigenous and Arab affairs in the Dutch East Indies from 1889 to 1906 further attests that his interest in Mecca was not only personal and scholarly but also synchronized with colonial ideologies. ${ }^{86}$

At the time he published his own work, Snouck Hurgronje was familiar with Sadiq Bey's photographs and at least one of his four books. Included in the Bilder-Atlas ( $\#_{1}$ and $\#_{3}$ ) is a tinted lithograph of the Masjid al-Haram and a collotype of the Ka'ba after two albumen prints by Sadiq Bey or their reproductions. In Mekka: Aus dem heutigen Leben, Snouck Hurgronje refers to Sadiq Bey's third book, Kawkab al-Hajj, and mentions the OttomanEgyptian military officer's work in a footnote with the following critical assessment: "in spite of all superficiality, there are many valuable data on the geography and ethnography of Arabia." ${ }^{87}$ Besides Sadiq Bey's photographic portfolios, the accessibility of his books is also worth emphasizing here. 
The Meccan doctor Sayyid 'Abd al-Ghaffar produced several early photographs of the Masjid al-Haram and Mecca. These circulated widely with the Bilder-Atlas and Bilder aus Mekka, although his signatures and captions were removed for the collotypes. Nevertheless, the traces of 'Abd al-Ghaffar's distinctive calligraphic signature, "Photograph by al-Sayyid 'Abd al-Ghaffar, doctor of Mecca" (fuțugrāfiyāt al-Sayȳ̄d 'Abd al-Ghaffār, țabīb $M a k k a$ ), and his prominently placed captions remain vaguely visible in several photographs of Bilder aus Mek$k a$. In the preface of this work, Snouck Hurgronje tellingly writes about a Meccan doctor whom he instructed in photography, without mentioning the name 'Abd alGhaffar: "Shortly after my two-volume work Mekka was completed with the Bilder-Atlas, I received a shipment of many very interesting recent shots from the Meccan doctor to whom I taught photography during my stay in the holy city." 88

Even though Snouck Hurgronje credits the Austrian explorer Siegfried Langer (1857-82) for a single photograph in the Bilder-Atlas, he does not mention 'Abd alGhaffar's name for his several photographs. Perhaps aesthetic concerns led him to remove 'Abd al-Ghaffar's overpowering signatures and captions, or perhaps he wanted to protect his source. ${ }^{89}$ As a series of letters between the two reveal, 'Abd al-Ghaffar hosted Snouck Hurgronje in Mecca and was a co-worker in their photographic studio. Upon departing from Mecca, Snouck Hurgrnoje left his photography equipment to 'Abd alGhaffar and commissioned him to take photographs during the Hajj. The consignments and letters from the doctor were passed on to Snouck Hurgronje through the Dutch vice consul P. N. van der Chijs in Jidda. ${ }^{90}$

These consignments not only included photographs by 'Abd al-Ghaffar but also those by Sadiq Bey from 1880-81 and perhaps some by another photographer who had taken pictures of recent Ottoman building commissions in Mecca. These photographs reached Leiden and appeared in the Bilder-Atlas and Bilder aus Mekka in the form of photographic prints and lithographs. ${ }^{91}$ According to a passage in Dalìl al-Hajj, Sadiq Bey met 'Abd al-Ghaffar in Mecca in 1885 , and then the two photographers traveled to Cairo together so that the latter could improve his dentistry skills. ${ }^{92}$ This explains 'Abd al-Ghaffar's and thus Snouck Hurgonje's access to Sadiq Bey's photographs. It is not certain whether 'Abd
al-Ghaffar met other military officers; however, the doctor's photographs also made their way into the Ylldiz Albums in Istanbul, whether through Sadiq Bey or some other intermediary.

\section{ARCHIVING THE HOLY IN ISTANBUL}

The Ylldız Albums, also known as the Abdülhamid Albums, are preserved in the Istanbul University Library; a set of copies is also kept at the Research Center for Islamic History, Art, and Culture (IRCICA) in Istanbul. Additionally, two large collections of albums are housed in the US Library of Congress and the British Library, as well as smaller collections of gift albums. ${ }^{93}$ The Ylldız Albums contain numerous depictions of cities within Ottoman territories and Europe. Of the albums in the Istanbul University Library, at least eleven include photographs from the Hijaz. ${ }^{94}$ Some of these albums consist of photographs by 'Abd al-Ghaffar, Sadiq Bey, and at least another member of the Ottoman military committee (perhaps 'Ali Bey), which served the court, the press, and artists. ${ }^{95}$

Album 90789 is exclusively comprised of photographs signed by 'Abd al-Ghaffar, which are mounted on cardboard and ruled in red. Here, his signatures and captions are untouched and fully legible (fig. 8), unlike in Bilder aus Mekka, where they were intentionally removed. The Leiden University Libraries have a larger collection of photographs signed by 'Abd al-Ghaffar, several of which were utilized in Snouck Hurgronje's publications (figs. 9-10). ${ }^{96}$ For instance, the first photograph in Bilder aus $\operatorname{Mekka}(\# 1)$, showing the courtyard of the mosque during the Friday prayer, can also be found in Album 90789 (\#4) in the Istanbul University Library and in the folder Or. 26.367 (\#4) in the Leiden University Libraries. The latter bears the signature of 'Abd al-Ghaffar in the lower middle and the caption "prayers around the Ka'ba" (alsalawat hawla al-Ka'ba) in the upper middle. ${ }^{97}$

Album 90770 contains Sadiq Bey's entire portfolio, with an additional photograph of Mount Uhud and the Tomb-and-Mosque of Hamza (not mentioned in his advertisement pamphlets). ${ }^{98}$ All the photographs in this album are mounted on cardboard with captions in ta līq script (fig. 11). Sadiq Bey's name is legible on all photographs except the one depicting Uhud, which might 


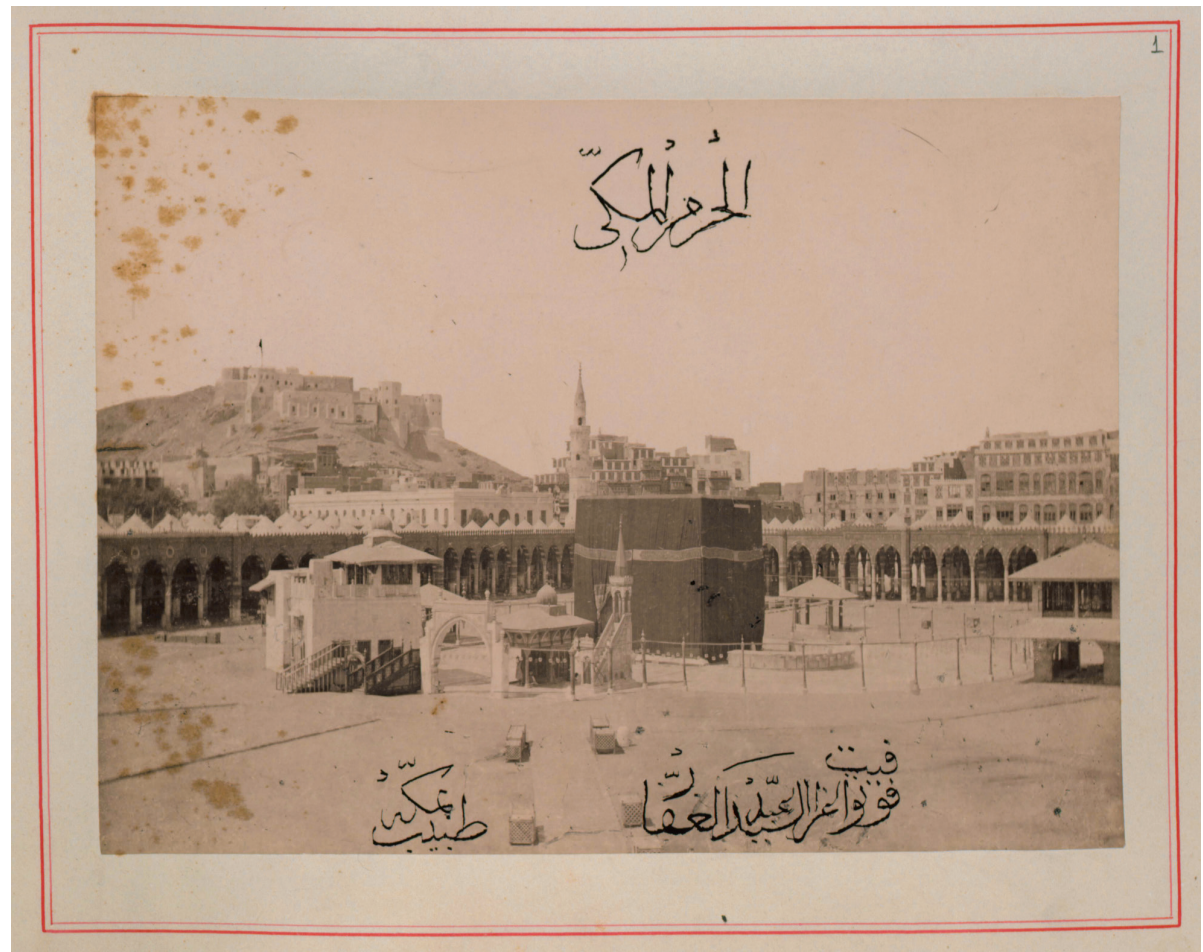

Fig. 8. Al-Haram al-Makkā. Signed by 'Abd al-Ghaffar, 188 os, albumen print, $31 \times 39.5 \mathrm{~cm}, 19.5 \times 25.5 \mathrm{~cm}$. Istanbul University Library, Rare Works Collection, no. 90789/1. (İstanbul Üniversitesi Kütüphanesi)

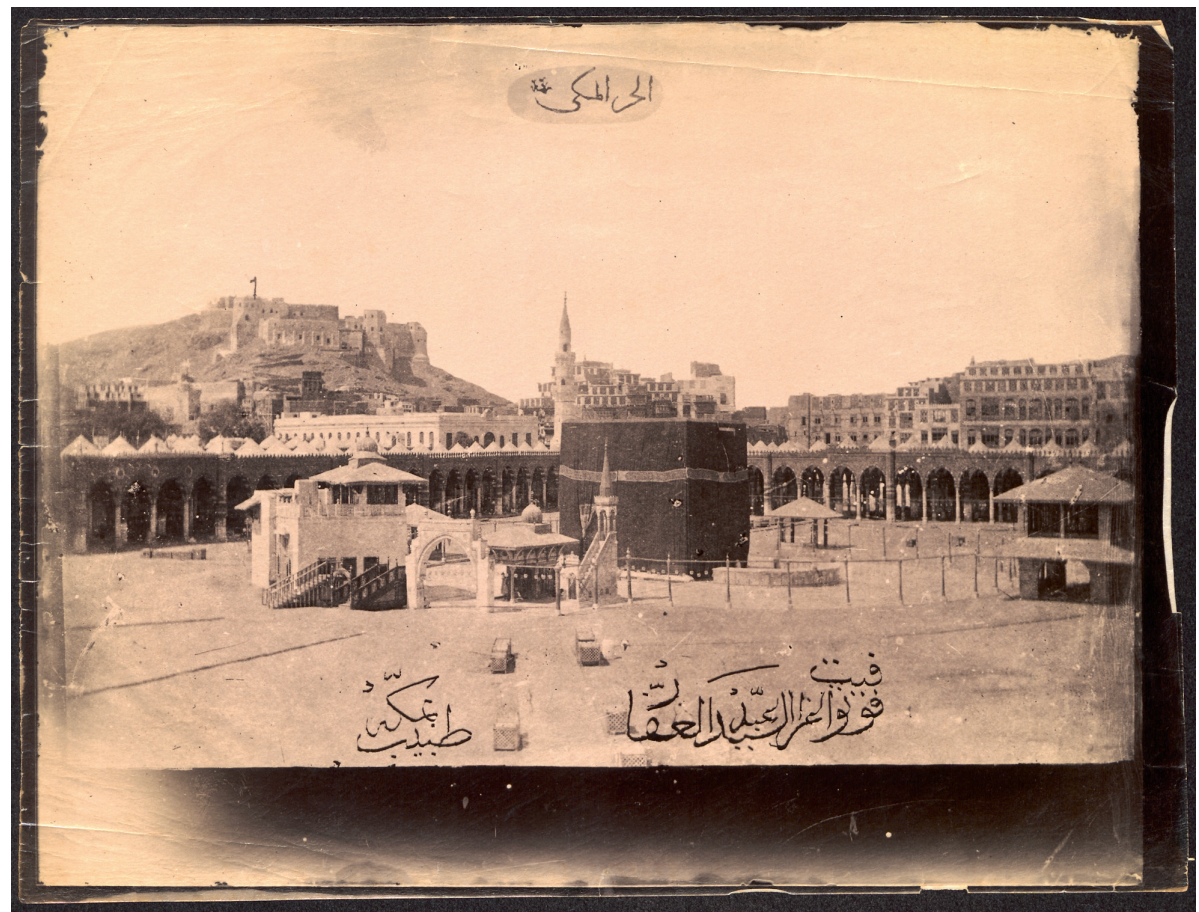

Fig. 9. Al-Hara $[\mathrm{m}]$ al-Makkā. Signed by 'Abd al-Ghaffar, $188 \mathrm{os}$, albumen print, $21 \times 28.2 \mathrm{~cm}$. Leiden University Libraries, Or. 26.367/5. (Leiden University Libraries) 


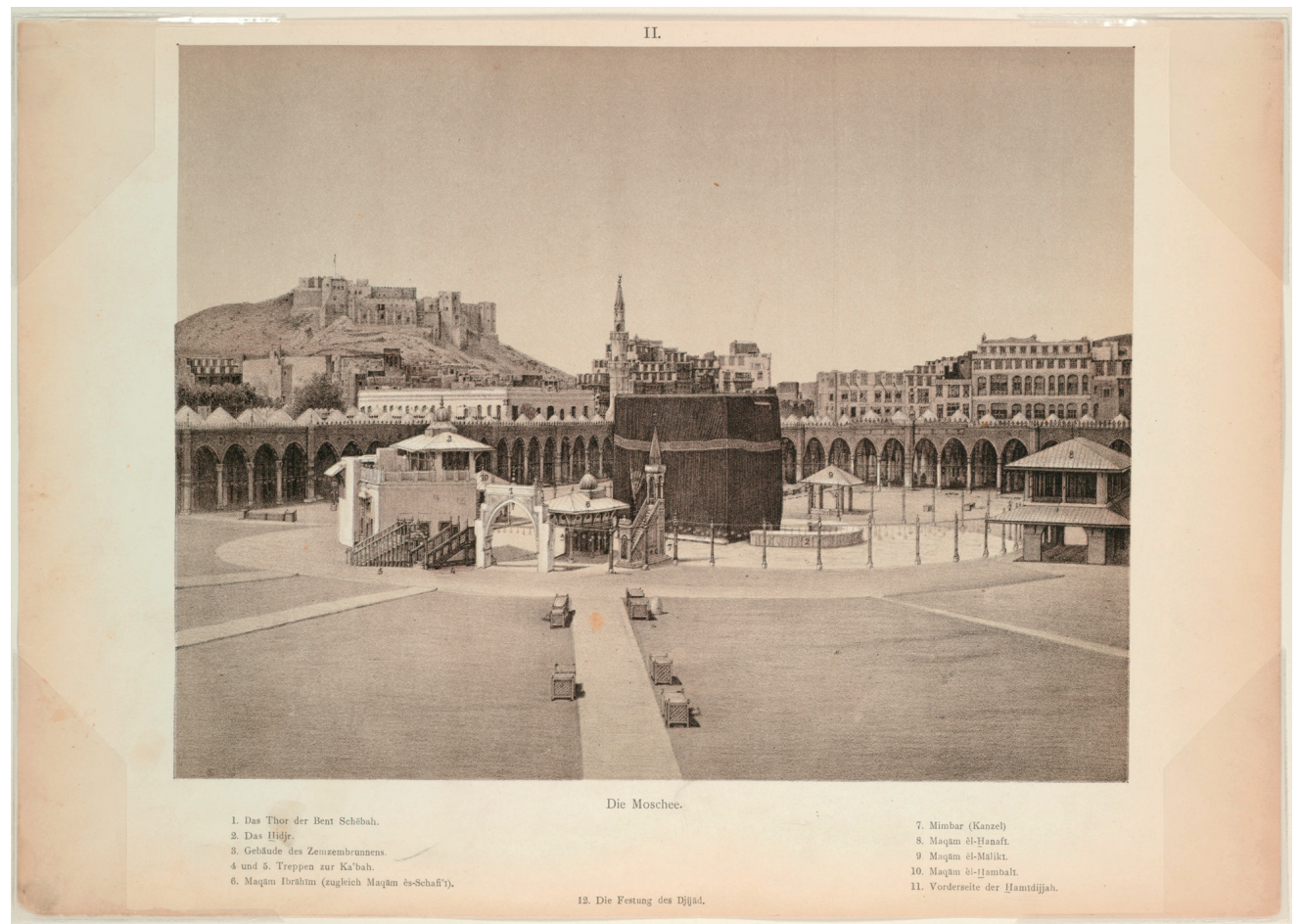

Fig. 10. Die Moschee. Tinted lithograph, $27 \times 36 \mathrm{~cm}, 20 \times 26 \mathrm{~cm}$. Christiaan Snouck Hurgronje, Bilder-Atlas, 1888, \#2. ("Die Moschee," The New York Public Library Digital Collections, accessed March 20, 2018, <https://digitalcollections.nypl.org/ items/510d47dc-47a7-a3d9-eo4o-eooa18o64a99>)

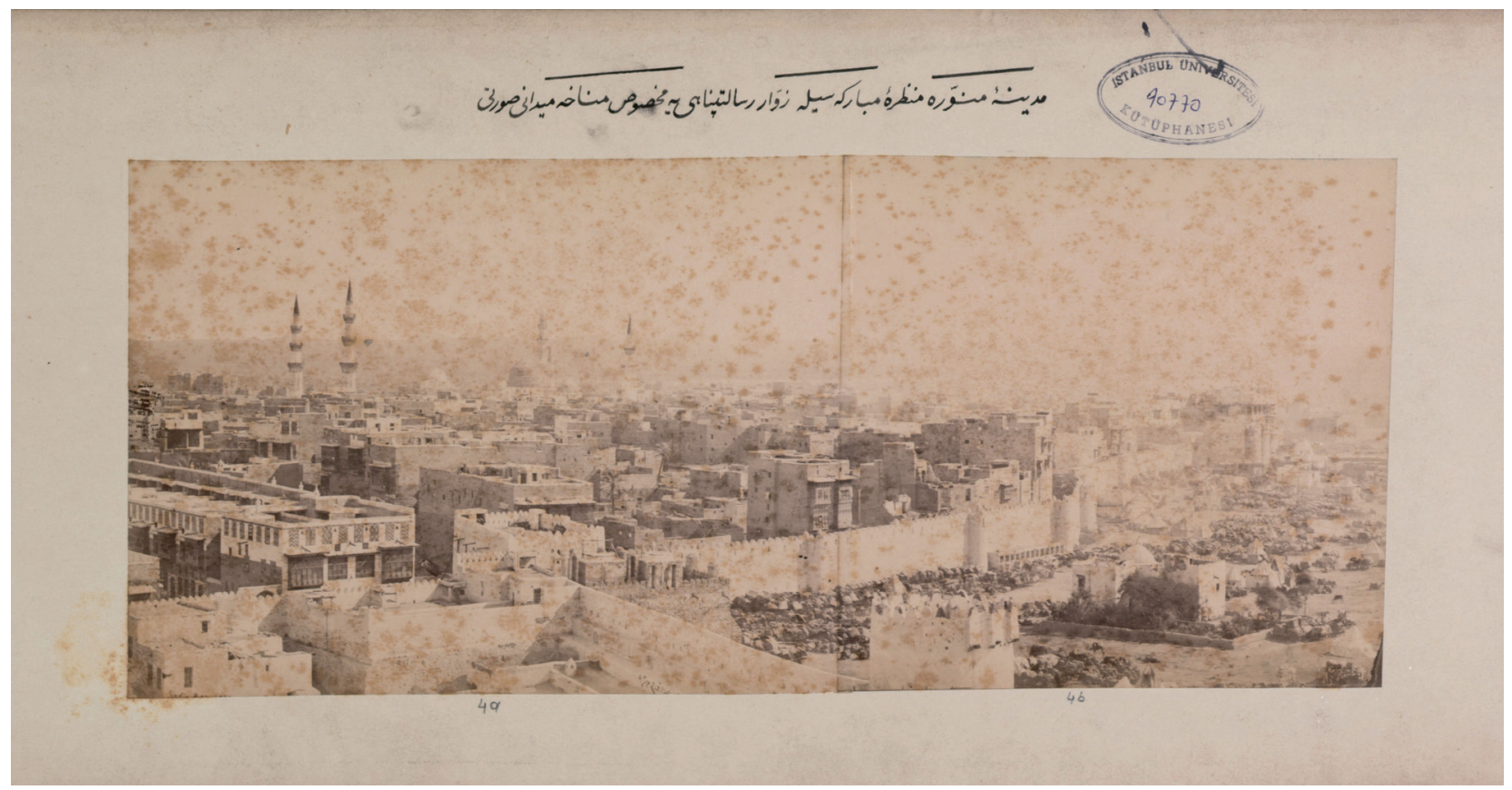

Fig. 11. Medīne-i Münevvere Manzara-i Mübärekesi. Signed by Sadiq Bey, Muharram 1298 (December 1880-January 1881), albumen print, $24 \times 62.5 \mathrm{~cm}, 16 \times 38 \mathrm{~cm}$. Istanbul University Library, Rare Works Collection, no. 90770/4. (İstanbul Üniversitesi Kütüphanesi) 


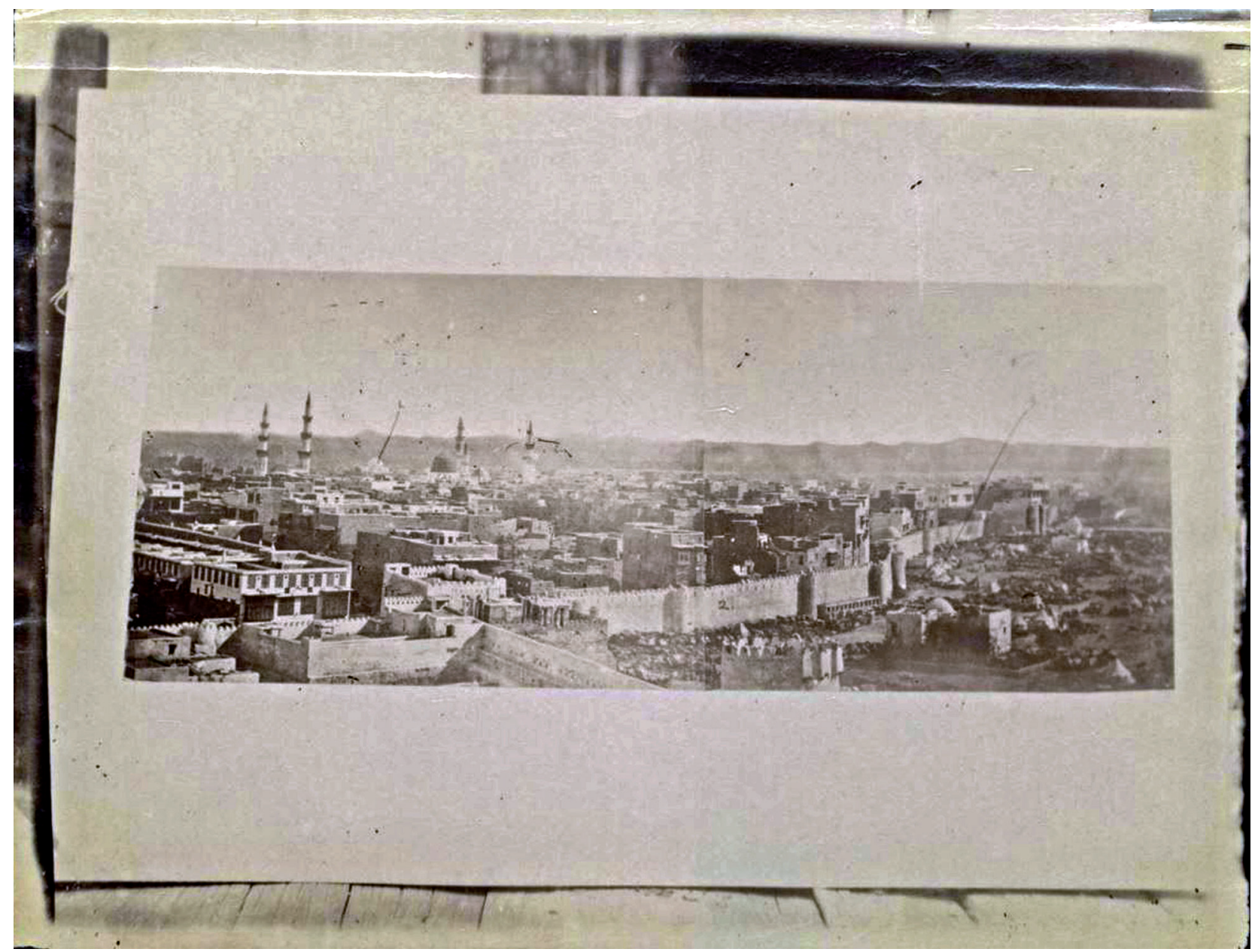

Fig. 12. Medina. Albumen print, $21.5 \times 27.6$ cm. Leiden University Libraries, Or. 12.288 L/16. (Leiden University Libraries)

have been blackened out in the lower left corner (\#6b). The rest are signed in French or Arabic, or in both languages, hinting at the diverse audience and wide circulation Sadiq Bey had in mind. Captions added later to the mounts were also carefully chosen to appeal to particular viewers/readers. For instance, Sadiq Bey's photographs in Album 90770 bore inscriptions in Ottoman Turkish, whereas those in the Victoria and Albert $\mathrm{Mu}-$ seum carried English captions. Copies of Sadiq Bey's photographs are also available in the Leiden University Libraries, even though some of them did not make it into Snouck Hurgronje's portfolios (fig. 12).

Albums 90743-49 consist of photographs of Mecca, Medina, Ta'if, Jidda, and Yanbu, which were likely taken by the aforementioned 'Ali Bey. ${ }^{99}$ These albums include several copies of the same shots and panoramas but with changes in brightness and contrast. For instance, Album 90743 displays a total of twenty-four photographs, including eight copies of a tripartite panorama of Mecca, a bipartite panorama of Medina (fig. 13), and a bipartite panorama of the Baqi' Cemetery outside Medina. On their ruled cardboard mounts, these photographs have Ottoman Turkish captions written in thuluth script. The Baqi Cemetery photographs further display legends in naskh script, which annotate the enumerated tomb structures on the photographs. Similarly, Album 90745 consists of two copies of the following nine photographs: Masjid al-Haram (looking north), Masjid al-Haram during Friday prayer (also looking north), Masjid al-Haram (looking south), Jabal 'Arafat, the valley of Abraham and 


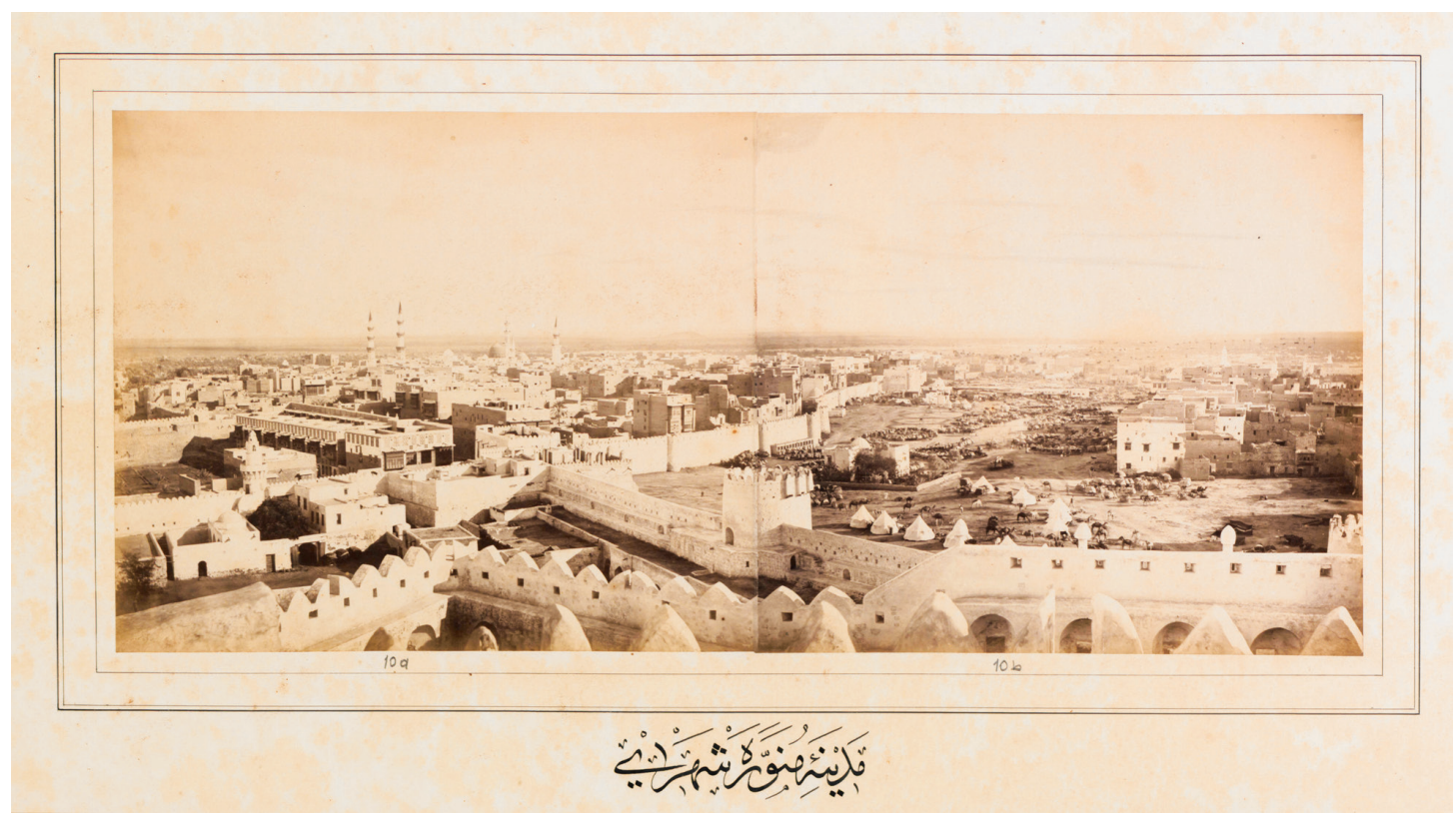

Fig. 13. Medine-i Münevvere Şehri. Albumen print, $51.5 \times 87.4 \mathrm{~cm}, 16.7 \times 38.3 \mathrm{~cm}$. Istanbul University Library, Rare Works Collection, no. 90743, 10a-b. (İstanbul Üniversitesi Kütüphanesi)

Jabal Nur, Mu'alla Cemetery, Masjid al-Nabawi, the residence of 'Abd al-Muttalib (Sharif of Mecca) in Beyaziyye, and Ta'if. The ruled photograph mounts are also inscribed with captions or legends in thuluth and naskh scripts.

Furthermore, Album 90877 consists of twenty photographs of troops, buildings, and processions in the Ottoman provincial cities of Erzincan and Antep, as well as five photographs of Mecca. The latter document imperial commissions in and around the holy city: the Hamidiyye Barracks (1884-85) and the police station (1882-83) near the Masjid al-Haram, the Artillery Barracks at Ciyad Square (1882-83), the Gayretiyye Barracks at Jabal Hind, and the hospital in Mina (1882-83). ${ }^{100}$ These photographs are very likely those mentioned in a document dated to $1885^{-86}$ in the Republic of Turkey's Presidency State Archives, which lists photographs of five state and military buildings (ebniye-i miriyye ve 'askeriyye) sent to the Ministry of the Interior (Dâhiliyye Nezāreti) by the governor of the Hijaz province, Osman Nuri Pasha. ${ }^{101}$ This document clearly shows one of the itineraries for the travel of photographs from Hijaz to Istanbul, which contributed to the "Hamidian visual archive." An undated letter from Snouck Hurgronje to
'Abd al-Ghaffar in the Leiden University Libraries also notes five such photographs and a photograph of the Egyptian mahmal among the consignments passed to P. N. van der Chijs. ${ }^{102}$ This letter, however, indicates an itinerary for the flow of photographs between the Hijaz and Leiden, which is the subject of the next section. ${ }^{103}$

\section{PUBLISHING ETHNOGRAPHIC RESEARCH IN LEIDEN}

The Bilder-Atlas (1889) consists of sixty-five photographic prints pasted on cardboard $(36 \times 27 \mathrm{~cm})$, with an addition of six tinted lithographs and four chromolithographs. The portfolio starts with collotype photographs and tinted lithographs of Masjid al-Haram and Mecca, continues with honorific portraits from Mecca and group portraits of pilgrims from Jidda, and ends with chromolithographs of objects from Mecca. The first two tinted lithographs of the Masjid al-Haram and Mecca are after photographs by Sadiq Bey and 'Abd alGhaffar. The former is after a bipartite panorama by Sadiq Bey that shows the holy mosque and city looking west from the mountain of Abu Qubays. On the lower 
left corner of the panoramas in the Istanbul University Library and Victoria and Albert Museum, one can read "Șadīq Bey 1880" in black Arabic script and "Sadic Bey" in white Latin script, aiming at legibility for different audiences. ${ }^{104}$ The latter depicts the courtyard of Masjid alHaram looking south (fig. 10). It is after a photograph by 'Abd al-Ghaffar that bears his signature and the caption "al-Haram al-Makkā," copies of which are now kept in the Istanbul University and Leiden University Libraries (figs. 8-9). ${ }^{105}$ The first six folios in the Bilder-Atlas depict the mosque and the city after photographs by 'Abd alGhaffar, Sadiq Bey, and perhaps another photographer whose works can also be found in Album 90877. ${ }^{106}$

Portraits follow the architectural photographs, with a sequence reflecting the hierarchical order of their sitters. ${ }^{107}$ The seventeenth folio in the Bilder-Atlas, a lithograph showing a piece of the kiswa (the textile covering of the Ka $\left.{ }^{\mathrm{b} a}\right),{ }^{108}$ separates portraits taken by Snouck Hurgronje and 'Abd al-Ghaffar in Mecca from those taken by the Dutch scholar in Jidda (except for a photograph by Siegfried Langer). ${ }^{109}$ Snouck Hurgronje adopted a systematic approach for his ethnographic studies. This is especially evident in the photographs of pilgrims from the Dutch East Indies and in the four chromolithographs of objects from Mecca that conclude the portfolio. ${ }^{110}$ The captions assigned by Snouck Hurgronje to group portraits of pilgrims, such as those from Borneo, Java, Maluku, and Sumatra, reveal the divergence of these photographs from honorific portraits. The regional classifications of Snouck Hurgronje's photographic documentation were driven by Dutch colonial endeavors. ${ }^{111}$ Furthermore, the collection of objects he acquired in the Hijaz hints at the planned structure of his ethnographic research. ${ }^{112}$

Bilder aus Mekka (1889) consists of twenty collotype photographs mounted on cardboard $(36 \times 27 \mathrm{~cm})$, made after photographs sent to Leiden by 'Abd al-Ghaffar shortly after Snouck Hurgronje completed the BilderAtlas and his volumes on Mecca. ${ }^{113}$ In contrast to the dominant ethnographic approach in the Bilder-Atlas, this second portfolio offers an overall view of Mecca and its environs, except for the last three photographs. ${ }^{114}$ The portfolio starts with a view of the Ka'ba taken from the courtyard of the Masjid al-Haram and continues with a panorama of the city on four pages, a frontal view of the Ottoman printing house, single photographs and pan- oramas of pilgrim camps and sites of the Hajj rituals (Mina, Muzdalifa, and 'Arafat), a group portrait of four men and a camel; it ends with two shots of an elaborately decorated bridal throne (rikah). Like the Hamidiyye Barracks and police station in the Bilder-Atlas, the printing house photograph in Bilder aus Mekka depicts a recent imperial commission in Mecca. ${ }^{115}$ All three buildings, with their whitewashed façades and neo-Classical architectural styles - which were common in other major cities of the empire-are visibly located in the city center. As the governor Osman Nuri Pasha noted in a report about the Hijaz, dated 1885 , new state buildings meant control over people and places and thus were needed by the state. ${ }^{116}$

Snouck Hurgronje's ethnographic approach was highly charged with Orientalist tropes, whether he was depicting pilgrims from the Dutch East Indies or women. In four instances, women appear prominently in the Bilder-Atlas: a portrait of a Javanese pilgrim in Jidda (\#19d), a portrait of a woman in Mecca (\#25a), a photograph of an elaborately dressed Meccan bride (\#25c), ${ }^{117}$ and a photograph of two women in contrasting costumes and postures (\#25d). ${ }^{118}$ Folio \#19 captures the diversity of pilgrims with a photograph of a female pilgrim and three photographs of two male pilgrims from Java, Sumatra, and Celebes. Folio $\#_{25}$, however, represents the harem with photographs of a Meccan woman, a servant, and a eunuch holding the baby of their patron (\#25b), a bride, and a pair of women standing and reclining. Bilder aus Mekka includes two more photographs related to the harem theme: one of a rikah, which Snouck Hurgronje describes as "the throne chair, on which one [the groom] of Mecca raises the virgin bride on the first night of marriage" (\#18a), and the other of a groom seated inside the rikah (\#18b). ${ }^{119}$ By adding folio \#25 to the Bilder-Atlas and folio \#18 to Bilder aus Mekka, Snouck Hurgronje perhaps played into the Orientalist stereotypes of his European audience. ${ }^{120}$

In the nineteenth century, photography was embraced by many disciplines for its potential to document the territorial breadth and subjects of empires, thereby mobilizing photographs for geopolitics and geopiety. ${ }^{121}$ Photographs from the Hijaz made their way into the Bilder-Atlas, Bilder aus Mekka, and the Yıldız Albums as well as many other destinations. The former two publications are products of Snouck Hurgronje's personal 


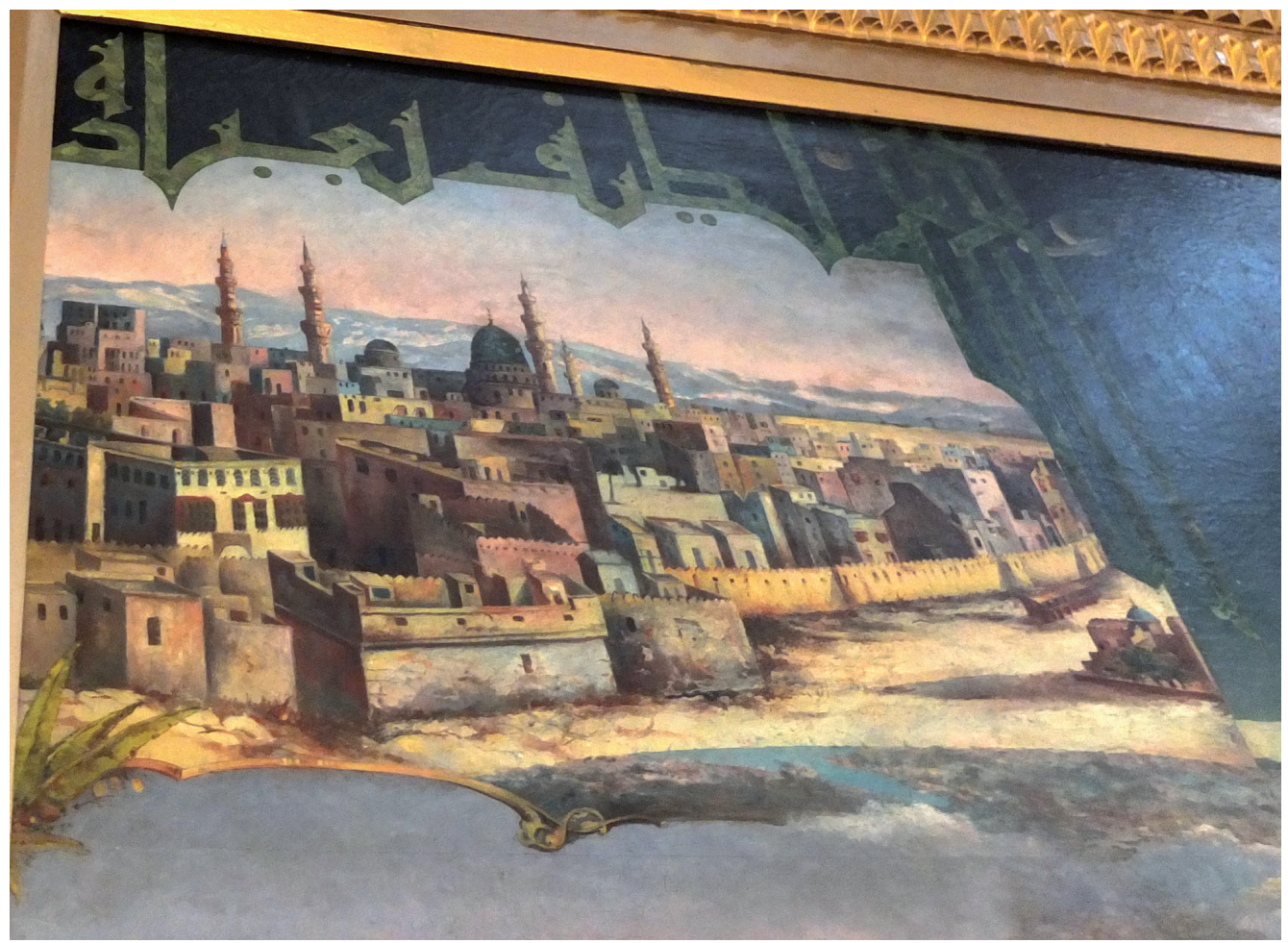

Fig. 14. Detail of Medina. Mi`marzade Muhammed 'Ali, 27 Ramadan 1323 (November 25, 1905), oil on canvas, $130.4 \times 195.4$ cm. Istanbul, Fatih Mosque. (Photo: Sabiha Göloğlu, with the permission of Fatih and İstanbul Müftülüğü)

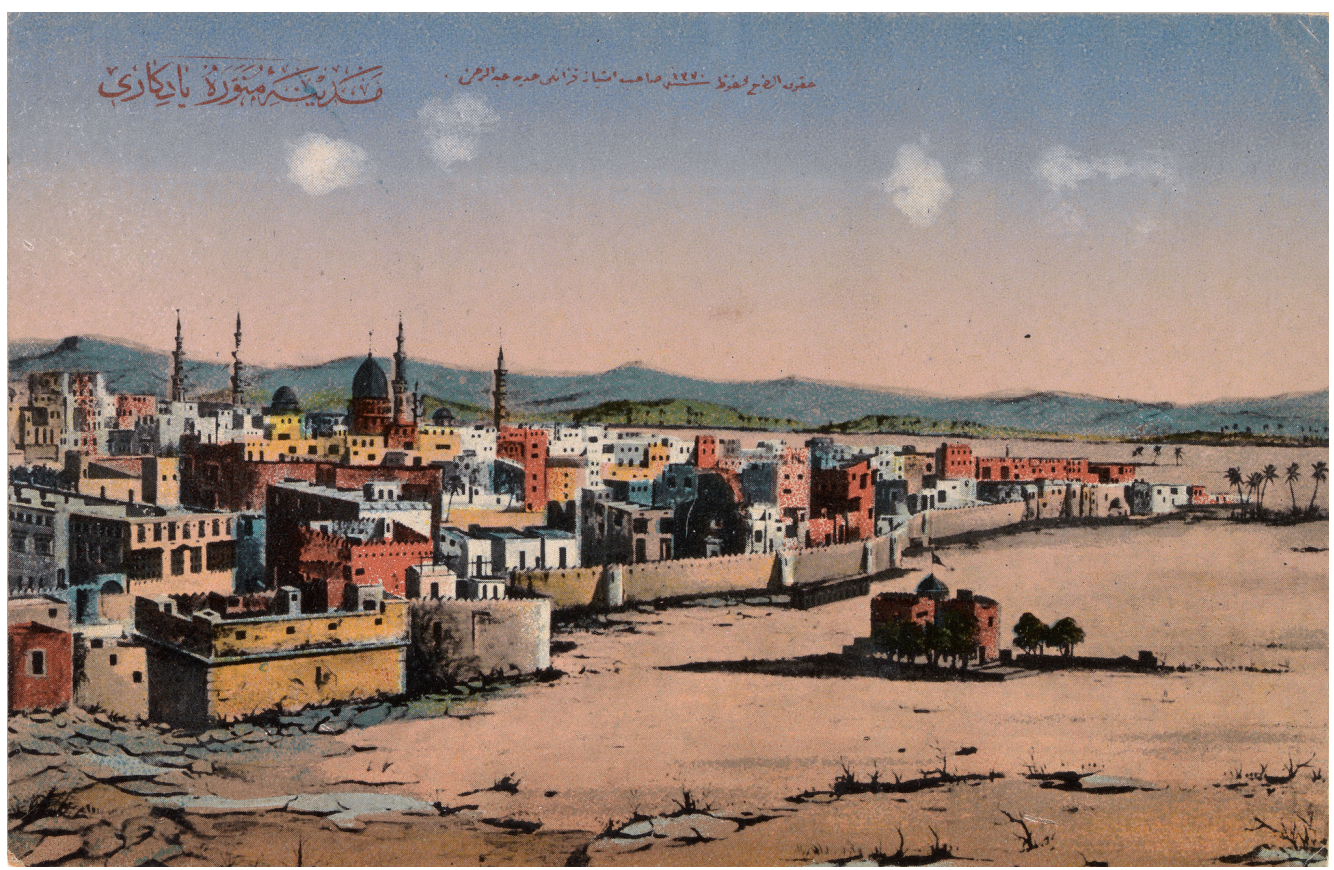

Fig. 15. Medīne-i Münevvere Yädigārı. Halftone and autochrome postcard, 1920, Emil Pinkau \& co., Leipzig, $8.9 \times 13.8 \mathrm{~cm}$. Hajj and the Arts of Pilgrimage, Khalili Collections, ARC.PC 473. (Khalili Family Trust) 


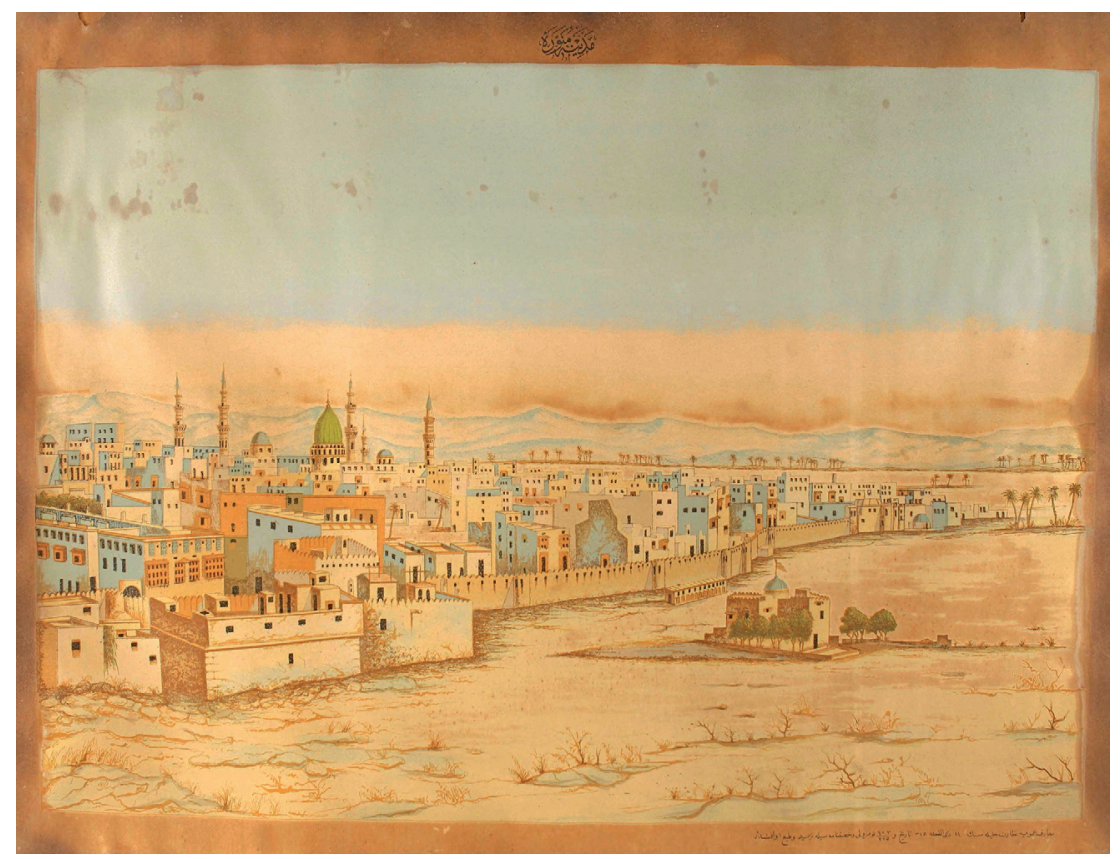

Fig. 16. Medīne-i Münevvere. Chromolithograph, $53 \times 69 \mathrm{~cm}$. 11 Zilkade 1315 (April 3, 1898), Painting Collection of the National Palaces, Dolmabahçe Palace, inv. no. 54/250o. (Milli Saraylar İdaresi Başkanlığı)

interest—guided by the Dutch government's ideological concerns - while the latter asserts the central authority of the Ottoman empire over distant provinces along with steps taken to control and modernize the state. Despite the different contexts in which they were produced, these photographic albums attest to a special interest in ethnography, geography, religion, and Ottoman rule in the Hijaz.

\section{TRAVELING IMAGES OF MEDINA}

The photographic oeuvres of Snouck Hurgronje, 'Abd al-Ghaffar, Sadiq Bey, and other members of the military committee intersect in the nodes of libraries, albums, prints, and paintings, such as the one in the Fatih Mosque. In this painting, a close-up view of the Ka ba and the Masjid al-Haram is paired with a general view of Medina. The colors, shades, and forms in the two images differ because the Masjid al-Haram image is after a photograph by 'Abd al-Ghaffar or its reproduction (fig. 8 ), whereas the Medina image is based on a color print, which in turn derives from a photograph by Sadiq Bey or another military officer (figs. 11, 13).122 A color postcard in the Nasser D. Khalili Collection of Islamic Art (ARC.PC 473) is based on a lithographic source that may have inspired Mi'marzade's depiction of Medina (figs. 14-15). ${ }^{123}$ This is an Emil Pinkau picture postcard printed in Leipzig in 1920-judging by the letter codes (SFOF) on the back - which reproduces an earlier chromolithograph of Medina. ${ }^{124}$ Two chromolithographs (no. 12/2636 and no. 54/2500) in the Painting Collection of the National Palaces (Dolmabahçe Palace) in Istanbul were probably produced around the same time (11 Dhu'lQa'da 1315 / April 3, 1898) as the postcard's lithographic source (figs. 15-16). ${ }^{125}$ These chromolithographs were designed to be hung on walls, as indicated by their large size $(53 \times 69 \mathrm{~cm}$ and $68 \times 88 \mathrm{~cm})$. The Earth's cracks in the foreground, the urban fabric in the middleground, and the mountains in the background are similar in the postcard and the large prints. Nevertheless, the openings in the buildings (e.g., windows and doors) and the color scheme vary significantly, confirming that different artists worked with the same medium.

These chromolithographs are perhaps after a Medina photograph shot from the Armory (Tophane) in the 


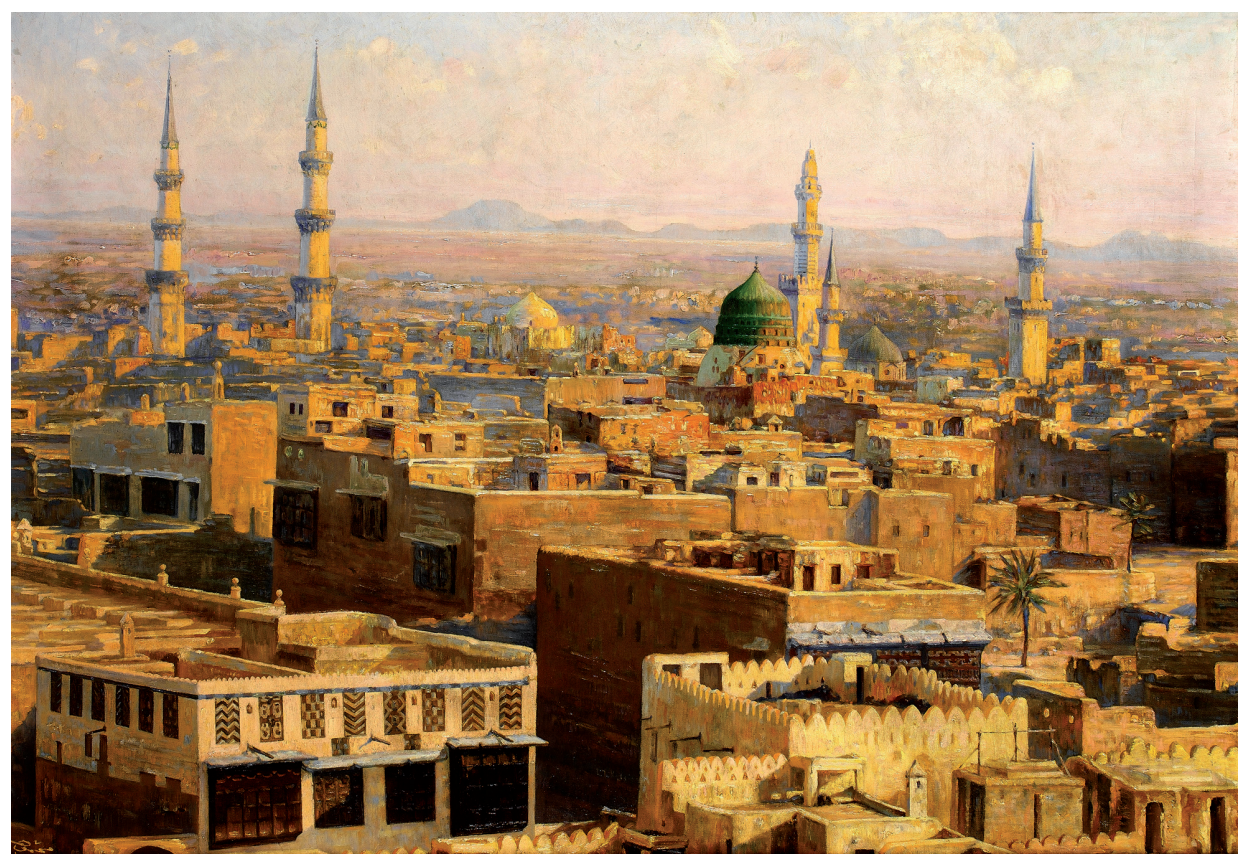

Fig. 17. Medina. Mahmud, 1332 (1913-14 or 1916-17), oil on canvas, $80 \times 115 \mathrm{~cm}$. Istanbul, Research Center for Islamic History, Art, and Culture. (Research Center for Islamic History, Art, and Culture)

northwest of the city, either by Sadiq Bey (fig. 11) or another member of the Ottoman military committee, possibly 'Ali Bey (fig. 13). Photograph \#10 in Sadiq Bey's portfolio (fig. 11) is the more likely choice, considering the shades and angles in the chromolithographs. Another possibility is that the lithographers had access to both photographs or their reproductions. A photograph of Sadiq Bey's photograph is found in the Leiden University Libraries, providing evidence that photographs were not always reproduced from their original negatives (fig. 12). ${ }^{126}$ Here, Sadiq Bey's albumen print was photographed using the same method, albeit reducing the details and size of the original.

Just like the Fatih Mosque painting, other works by Ottoman artists visualize the Haramayn on canvas, such as the paintings of the Masjid al-Haram and Medina preserved in the IRCICA. Both of these are signed by Mahmud and dated to 1332 (1913-14 or 1916-17) in the lower left corner. ${ }^{127}$ The original source for the Medina painting is likely the bipartite panorama taken from the Armory (fig. 17). Both Sadiq Bey and 'Ali Bey captured the city from a very similar angle and viewpoint, which makes it difficult to determine which Medina photo- graph was used as a source in Mahmud's painting (figs. $11,13)$. At this juncture, a comparison of the shadows cast in each photograph suggests figure 13 as the most likely source. Nevertheless, Mahmud might have seen both photographs in the Yıldız Albums or had access to reproductions of figures 11 and 13 in different contexts. Photographs of the holy sites were available in illustrated journals from the late nineteenth and early twentieth centuries. ${ }^{128}$ Rather than using the entire panorama of the city, Mahmud zoomed in on his source, highlighting the minarets and the Green Dome of the Masjid al-Nabawi, which are much smaller in the albumen print.

A print edition of the Moroccan Sufi leader Sulayman al-Jazuli's (d. 1465) Dalāil al-Khayrāt (Proofs of Good Deeds), a text consisting of blessings for the Prophet Muhammad (șalawāt), further epitomizes the versatile utilization and contexts of photographic reproductions. The Dalä'il al-Khayrät was a very popular Sunni prayer book, not only in North Africa and the Ottoman lands, but also in different parts of the Islamic world, from Ethiopia to Indonesia. ${ }^{129}$ Its manuscript and print copies were widely illustrated with a selection of images, from 


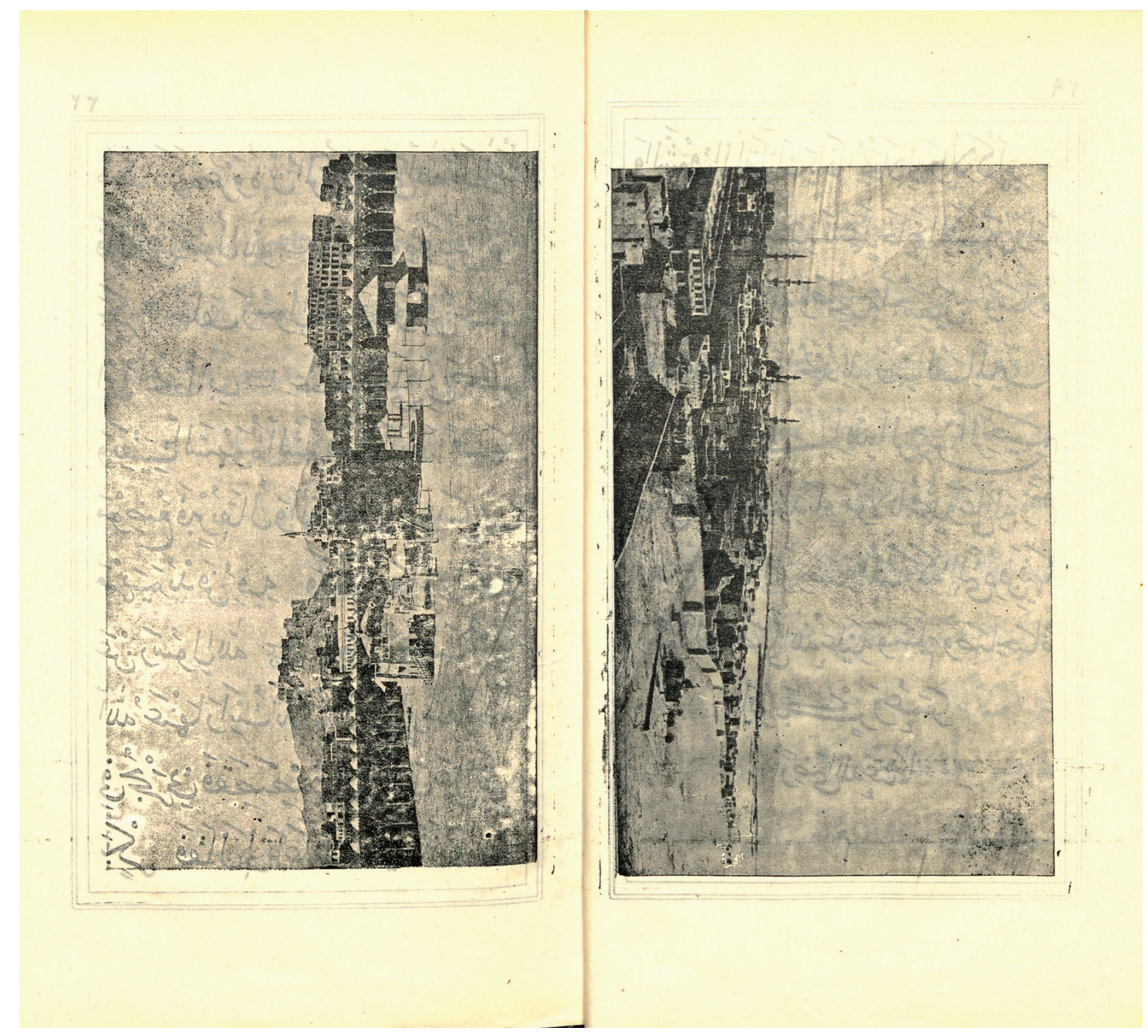

Fig. 18. Mecca and Medina. Sulayman al-Jazuli, Dalāil al-Khayrāt, 1333 (1914), Cairo: 'Abd al-Rahman Muhammad. Leiden University Libraries, 8203 C 15, pp. 30-31. (Leiden University Libraries)

the tombs of the Prophet Muhammad and the caliphs Abu Bakr and 'Umar, to Mecca and Medina.

The print edition in question was published in Cairo in 1914 in cliché technique with a double-page Masjid al-Haram and Medina composition (fig. 18).130 These prints were perhaps made after reproductions of photographs by Sadiq Bey and 'Abd al-Ghaffar, which appeared in postcards, illustrated journals, and books. The image on the right-hand page might well be after a reproduction of Sadiq Bey's Medina photograph (fig. 11).
The Medina print lacks certain details of the original photograph (such as the pilgrims' encampment outside the city walls), but it displays an enhancement of the background with silhouettes and the police station (żābıta karakolu) with palm trees. Similarly, the image on the left-hand page might be after a reproduction of 'Abd al-Ghaffar's Masjid al-Haram photograph. However, the Mecca print covers a larger area than the photograph in the Ylldız Albums or the tinted lithograph in the Bilder-Atlas (figs. 8, 10). This edition of the Dalä'il 


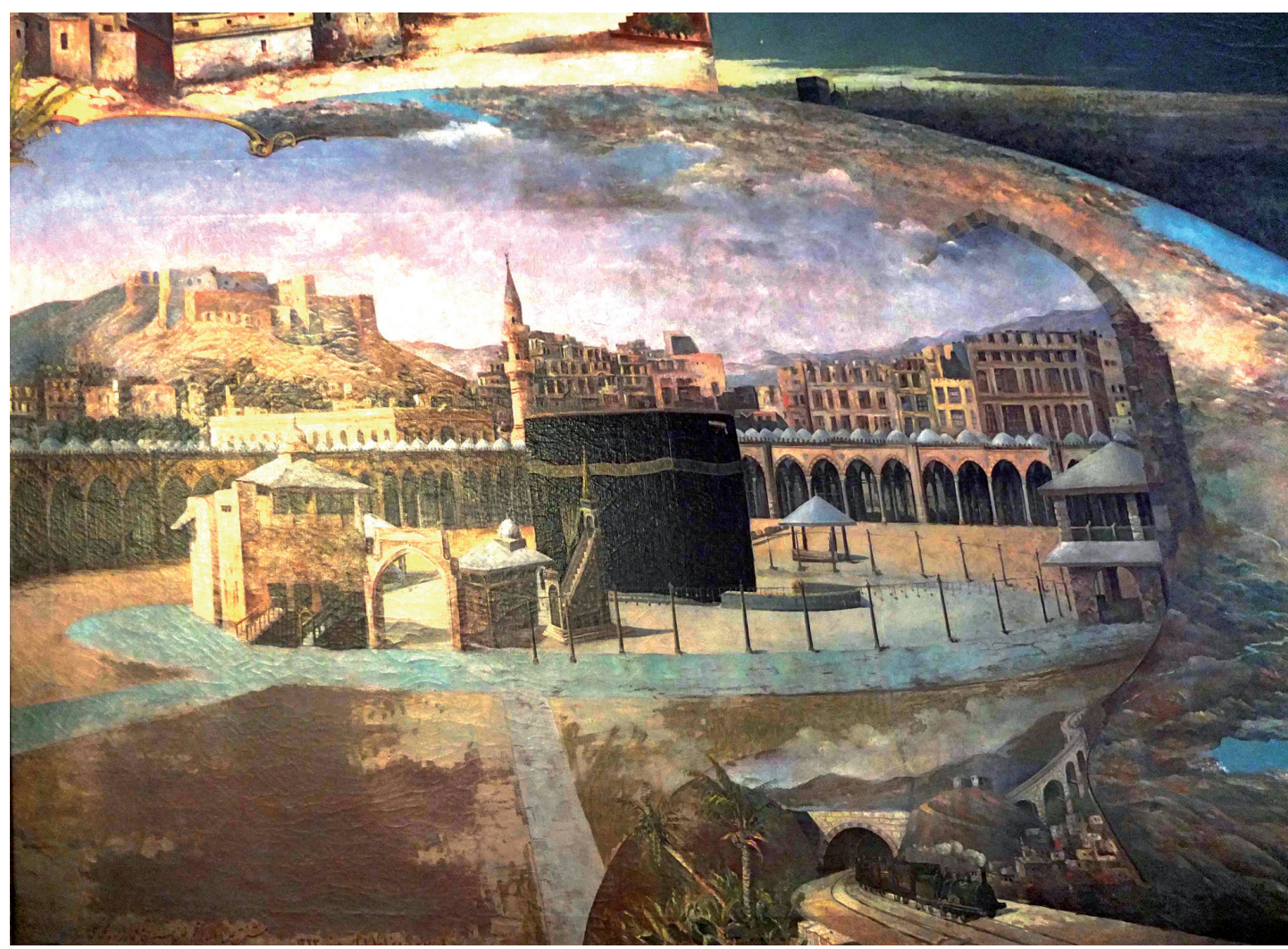

Fig. 19. Detail of Mecca. Mi'marzade Muhammed 'Ali, 27 Ramadan 1323 (November 25, 1905), oil on canvas, $130.4 \times 195.4$ cm. Istanbul, Fatih Mosque. (Photo: Sabiha Göloğlu, with the permission of Fatih and İstanbul Müftülüğ̈̈)

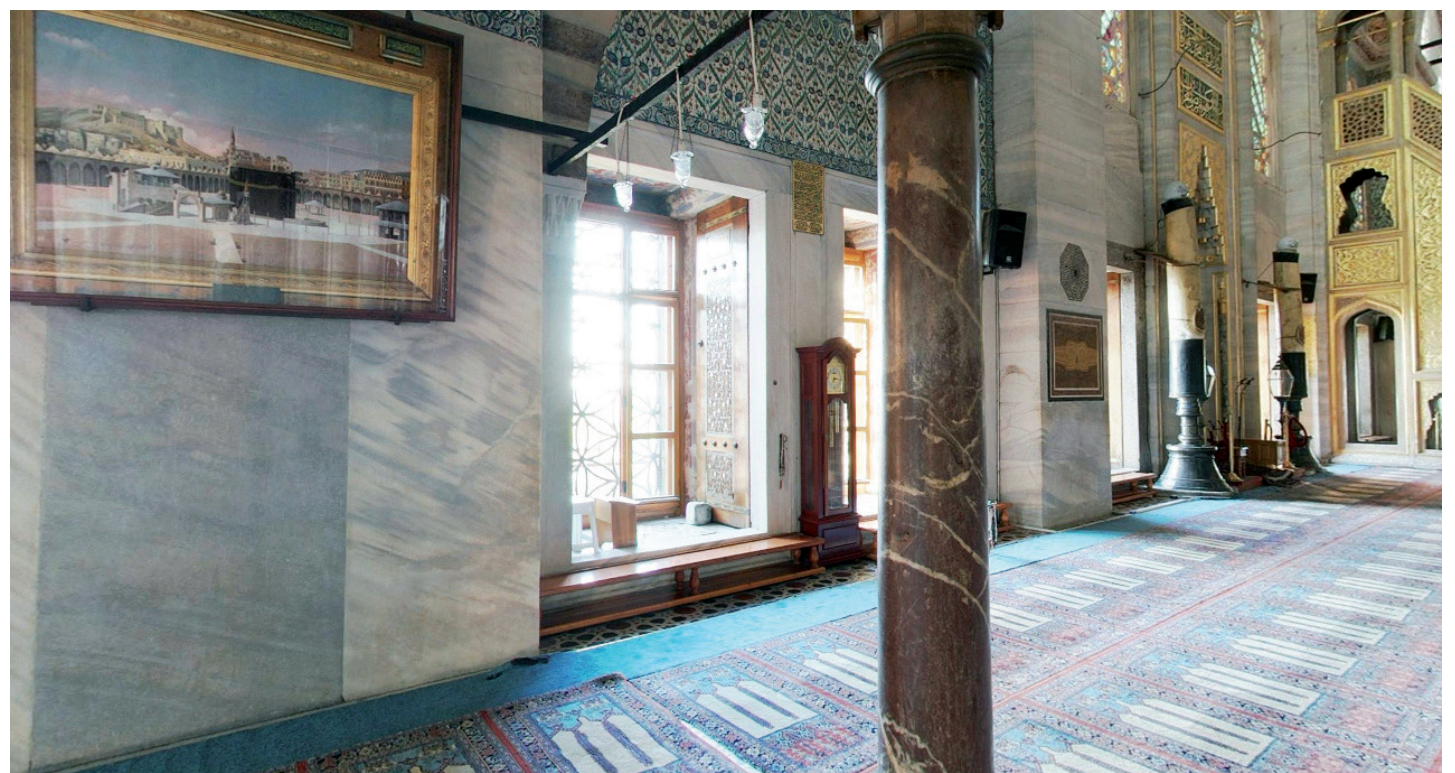

Fig. 20. Courtyard of the Masjid al-Haram. Mi'marzade Muhammed 'Ali, 1321 (1903-4), oil on canvas. Sultan Ahmed Mosque. (<http://www.3dmekanlar.com/sultanahmet_camii.htm>) 


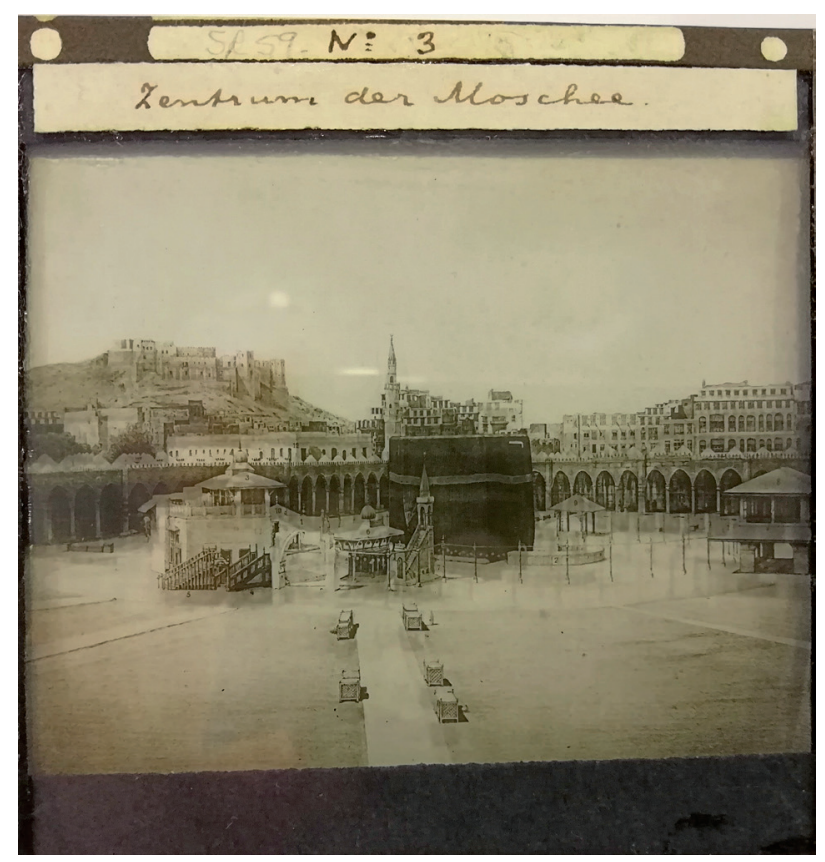

Fig. 21. Zentrum der Moschee. Lantern slide, after 1889, $8.3 \times$ $8.3 \mathrm{~cm}$. Leiden University Libraries, Said-Reute Collection 59/3. (Leiden University Libraries)

al-Khayrāt hence exemplifies the use of photographic images, which have a long-standing but steadily changing illustrated manuscript and print tradition. Furthermore, similar indirect transfers of images lead one to question the indexical quality of photographs and their presupposed "truthfulness" and "authenticity" compared to other modes of representation.

\section{TRAVELING IMAGES OF MECCA}

Mi'marzade used the same photograph by 'Abd al-Ghaffar when depicting the Masjid al-Haram in his painting in the Fatih Mosque and in another painting in the Sultan Ahmed Mosque dated 1321 (1903-4) (figs. 19, 20). ${ }^{131}$ The latter painting depicts only the Masjid al-Haram, as opposed to the multilayered composition of the former. Moreover, it has a palette of warmer tones and brighter light-a slightly different interpretation of the black and white photograph-and is narrower than the former. For both paintings, Mi`marzade must have had access to a copy or reproduction of 'Abd al-Ghaffar's photograph and utilized it according to his specific intent. A copy of the Meccan doctor's photograph is now preserved in the Istanbul University Library in an album of fourteen photographs, all signed by 'Abd al-Ghaffar (fig. 8). ${ }^{132}$ The Leiden University Libraries also possess a photograph of this albumen print but not a copy from the original negative (fig. 9). ${ }^{133}$ Figures 9 and 12 ended up in Leiden, perhaps because 'Abd al-Ghaffar was not able to send the original copies or glass negatives of his and Sadiq Bey's photographs to Snouck Hurgronje. A tinted lithograph was made after figure 9 and was published in the Bilder-Atlas (\#2); in this case, the change in medium expanded the audience of the image (fig. 10).

Apart from being included in the Bilder-Atlas, the lithograph of the Masjid al-Haram also found an audience as a lantern slide (fig. 21). This lantern slide belongs to a box of twenty-five, now preserved in the Leiden University Libraries. ${ }^{134}$ These slides have German captions, and a separate sheet in the box also repeats the captions. Other lantern slides in this box were made after photographs by 'Abd al-Ghaffar, Sadiq Bey, and Snouck Hurgronje or their reproductions in the BilderAtlas. As a projection on a large screen, a lantern slide could reach many more viewers at once, unlike single photographs or albums that could only be viewed by a limited number of people at any given time. These glass slides must have been prepared in the early twentieth century; however, not all of them are contemporaneous or by these three photographers. For instance, the last slide appears to have been a later addition to the slide box, since it consists of a portrait of 'Abdulaziz bin Sacud (r. 1932-53), the founder of the Kingdom of Saudi Arabia. ${ }^{135}$ Moreover, a single slide of Sadiq Bey's Mecca panorama is preserved in the Nasser D. Khalili Collection, while five slides of all three photographers' works were auctioned at Sotheby's in 2017. These six slides have German captions that include the name of the producer, Theodor Benzinger of Stuttgart, a commercial manufacturer of lantern slides. ${ }^{136}$

Postcards also served a commercial purpose apart from their communicative, commemorative, and collectible aspects. The Medina postcard has a Mecca counterpart, which must be after the Masjid al-Haram photograph by 'Abd al-Ghaffar or one of its reproductions (figs. 15, 22). ${ }^{137}$ Both postcards share the same color palette and inscriptions (except for their captions). 


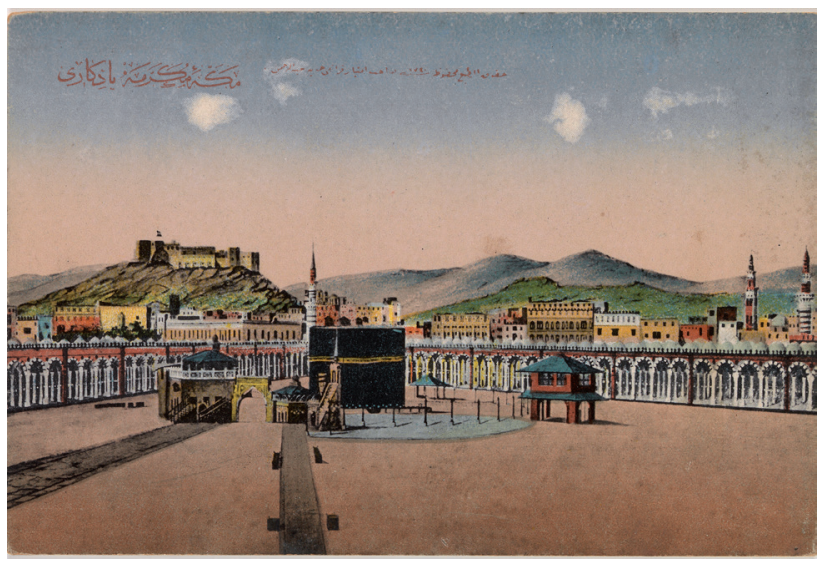

Fig. 22. Mekke-i Mükerreme Yādigārı. Halftone and autochrome postcard, 1920, Emil Pinkau \& co., Leipzig, $9.1 \times 13.6$ $\mathrm{cm}$. Hajj and the Arts of Pilgrimage, Khalili Collections, ARC. PC 472. (Khalili Family Trust)

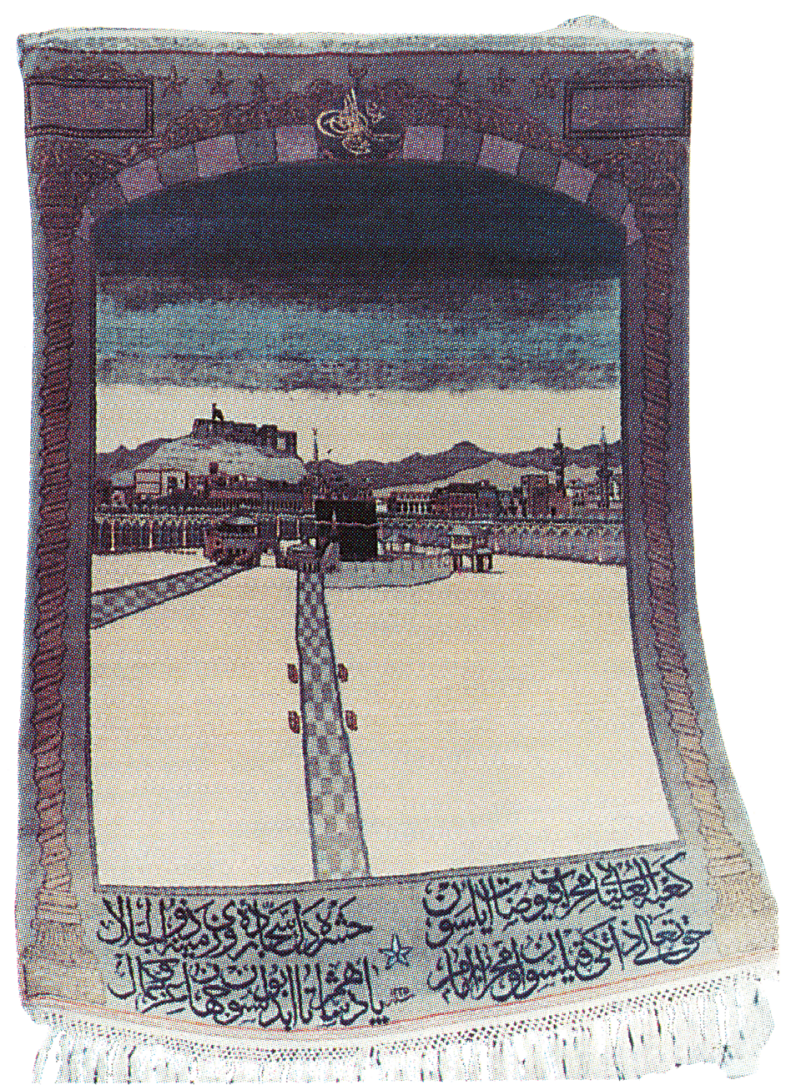

Fig. 23. Masjid al-Haram. Hereke prayer rug, 19o9, private collection. (Aldoğan, "Konya Mevlāna Müzesindeki Kābe Tasvirli Bir Seccade," 164)
The Khalili copies of these postcards have no text on the back, suggesting that they were not in postal circulation. As indicated by their captions- "Keepsake of Medina the Illuminated" (Medīne-i Münevvere Yädigārı) and "Keepsake of Mecca the Blessed" (Mekke-i Mükerreme Yādigārı) - these two copies must have initially been produced as souvenirs of the holy sites, just like several other affordable and portable mementos depicting the Haramayn. ${ }^{138}$

Another example demonstrating the way in which 'Abd al-Ghaffar's photographic view of the Masjid alHaram circulated can be found in an Ottoman Hereke prayer rug, dated 1325 (1909) (fig. 23). ${ }^{139}$ Its designer/ weaver must have had access to a copy or reproduction of the photograph. Similar to the Fatih Mosque painting propagating the sultanate and caliphate of 'Abdülhamid II, this prayer rug celebrates the enthronement of Sultan Mehmed Reşad (r. 1909-18) with his țugrā (imperial cypher) in the upper middle and panegyrics in the lower registers:

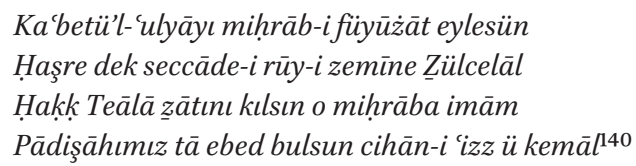

May God make the exalted Ka'ba the mihrab of prosperity, The prayer rug of the earth till the Day of Judgment.

May God make him the imam to that mihrab,

Our sultan shall find eternity, glory, and perfection of the universe.

This stanza celebrates Mehmed Reşad's enthronement and his caliphal authority by referring to him as the imam of the Ka ba. By combining the photographic view of the Masjid al-Haram and the sultan's tugra $\bar{a}$, the poem communicates that the Ottomans not only possessed political power but also religious authority over the Haramayn. Therefore, the designer/weaver used a photographic image to visualize the holy mosque as well as to serve an ideological purpose. Here, it is not easy to identify 'Abd al-Ghaffar's image due to the dramatization of the photographic view from the Ka'ba toward the archway framing the scene. Such liberation from the camera angle is not discernable in other uses of the same photograph. Here, a vista was created through which worshippers could visualize themselves in the holy mosque via their acts of prayer and prostration. When laid on the 
floor and superimposed with the qibla direction, the photographic reality of the prayer rug could reinforce a sense of praying inside the arcades of the Masjid al-Haram. In these examples and others, the translation of a photograph into different media exceeded simple copying because it included coloring, assembling, staging, and modifying images to represent religious and political power, and above all, to create virtual sacred space as if one were praying in the holy site proper.

\section{QIBLA DECORUM}

Whereas prayer rugs and qibla compasses (kııblenüma $\bar{a})$ with images of the Ka'ba, the Masjid al-Haram, and Mecca were temporarily oriented towards the qibla for the prayer, several other images of the Haramayn were placed towards the qibla direction for longer durations. A certain principle governed the architectural placement of Kaba-related objects across different regions and periods of the Islamic world. There is not much information about the provenance of the Fatih Mosque painting and whether it was meant to be publicly displayed. However, its most recent location conforms with the ongoing practice of placing Haramayn images in the qibla direction (fig. 2). Objects associated with the Ka ba and representations of Mecca and Medina were usually applied, inserted, or hung either on mihrab walls, walls or pillars parallel to the mihrab, or the most appropriate surfaces in the qibla direction. Such a spatial propriety or etiquette in the treatment of Mecca and Medina images can be described as a "qibla decorum," having served as a governing code for a variety of media over the centuries. ${ }^{141}$ Today, a number of ceramic tiles, wall paintings, prints, and photographs can be found in situ that confirm this spatial practice. ${ }^{142}$ Based on the writings of the French archaeologist and Egyptologist Émile Prisse D'Avennes (d. 1879) and the spatial contexts of Mecca tiles, Charlotte Maury points out that the ceramic panels with images of Mecca that were faced during the performance of the daily prayer could have operated with mihrabs, or as mihrabs, in order to engage "vision and sense of orientation together."143

The same qibla decorum can also be observed in the placement of Mi'marzade's other painting of the Masjid al-Haram in the Sultan Ahmed Mosque (fig. 20). The

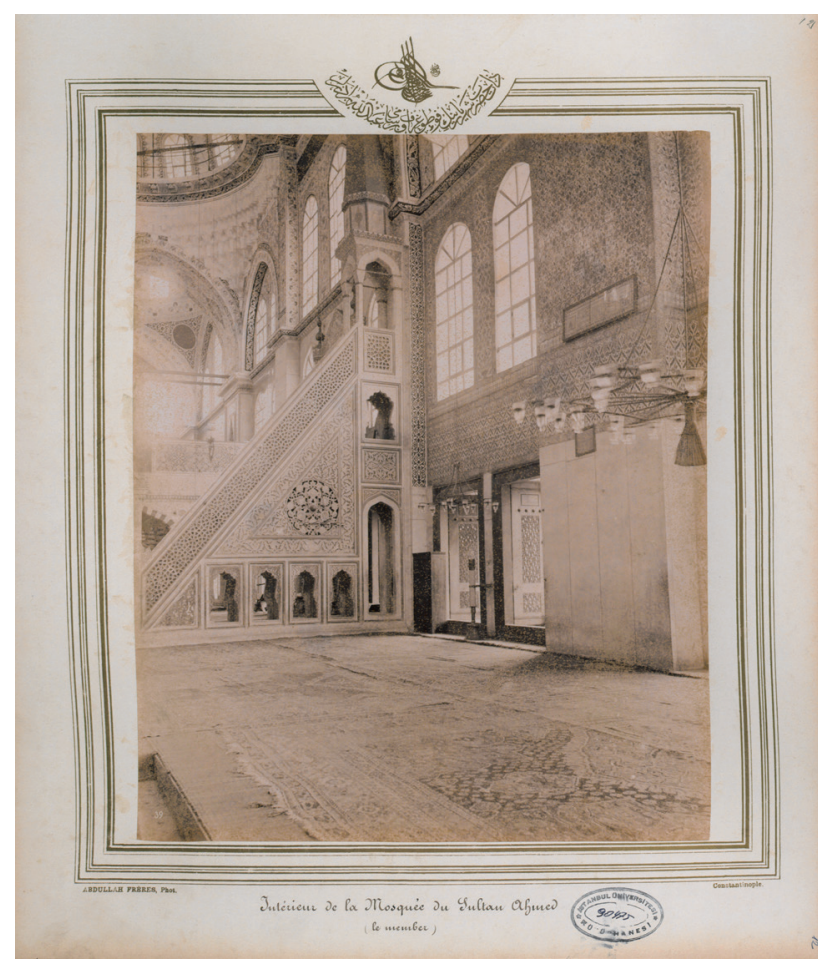

Fig. 24. Intérieur de la Mosquée du Sultan Ahmed (le member). Abdullah Frères, ca. 1894, $5^{0} \times 44 \mathrm{~cm}, 38 \times 31 \mathrm{~cm}$. Istanbul University Library, Rare Works Collection, no. 90475/12. (İstanbul Üniversitesi Kütüphanesi)

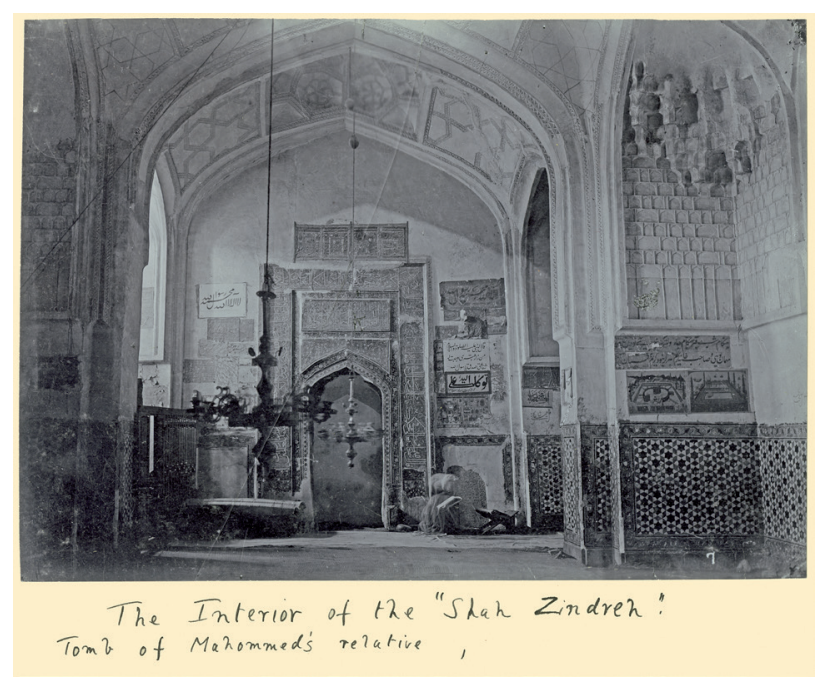

Fig. 25. Interior of the 'Shah Zindreh' Tomb of Mohammed's Relative. Taken by Morgan Philip Price, 1910-11, $26.6 \times 36 \mathrm{~cm}$, $12.1 \times 17 \mathrm{~cm}$. London, Royal Geographical Society, F 37/49. (Royal Geographical Society) 
painting is located to the left of the mihrab and under the deck of the royal prayer loge. A photograph of the Sultan Ahmed Mosque by the Abdullah Frères depicts the right-hand side of the mihrab and the minbar circa 1894 (fig. 24). This photograph shows a framed pilgrimage scroll hanging on the tiles and between the windows of the mihrab wall. ${ }^{144}$ Despite the blurriness of the image, it can be discerned that the horizontal scroll has five sections corresponding to different sites of pilgrimage and visitation in and around Mecca and Medina. Today, the pilgrimage scroll is no longer in place; however, the Masjid al-Haram painting hangs on the mihrab wall, emphasizing the qibla direction.

Another interior shot depicts the shrine of Qutham ibn 'Abbas, a cousin of the Prophet Muhammad, in the Shah-i Zinda complex in Samarkand (fig. 25). This photograph was taken by the British journalist Morgan Philips Price in 1910-11. It shows the mihrab of the shrine, in front of which two Qur'an stands and a blurry seated figure can be seen. Here, images of the holy sites appear in at least three different spots above the tile revetments. First, two perspectival views of Mecca and Medina catch one's eye under the muqarnas on the right-hand side. Second, a bipartite composition of the Islamic holy sites appears on the right-hand side of the mihrab. And finally, a four-part composition of the pilgrimage and visitation sites stands out above the tile decoration of the mihrab. As in figure 24, this must also be a horizontal pilgrimage scroll, but it is affixed between two pieces of wood and then divided in half by another.

Şule Aksoy and Rachel Milstein note that some of the thirteenth-century Ayyubid and Mamluk pilgrimage certificates in the Museum of Turkish and Islamic Arts in Istanbul, which were found in the Great Mosque of Damascus in 1893, have "remnants of either a solid support or a frame," suggesting that they might have been hung in mosque spaces. ${ }^{145}$ The Sultan Ahmed and Shah-i Zinda photographs illustrate how pilgrimage certificates could be placed and used in public spaces (figs. 24-25). Besides attesting to pilgrimage (major or minor, one's own or proxy), enabling material remembrance, and assigning social prestige and religious competence to the owners of these certificates, such displays oriented towards the qibla simulated travel to the holy sites. As David Roxburgh points out, pilgrims' kinetic and aural memories could be activated when the images and

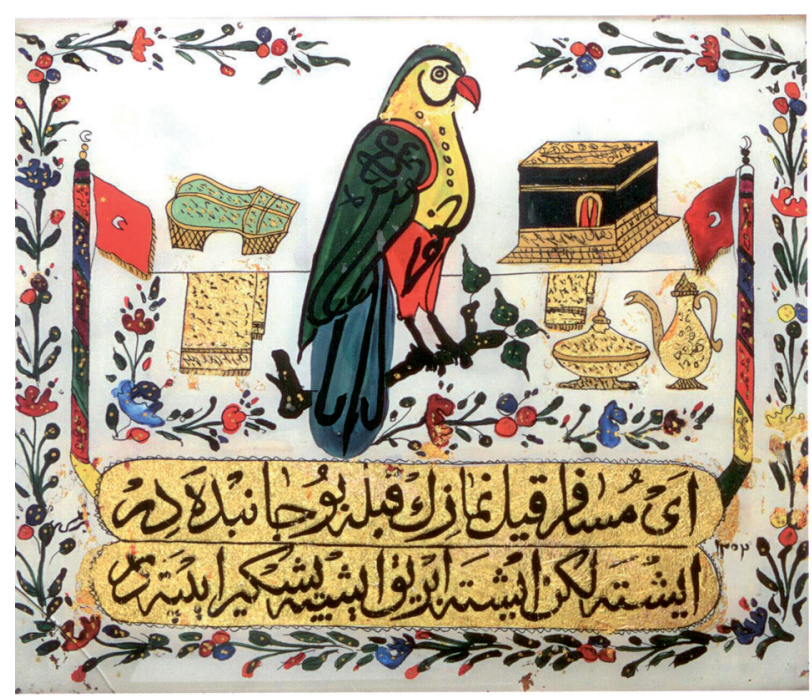

Fig. 26. Ka'ba panel. Reverse glass painting, early twentieth century, $5^{\circ} \times 65 \mathrm{~cm}$. Auctioned at Nişantaşı Müzayede. (Nişantaşı Müzayede, 31 Mayıs 2015, lot 705)

texts of pilgrimage certificates were encountered. ${ }^{146}$ Other depictions of the holy sites could also activate the imaginations of those who had never been to the holy sites, or the memories of those who had already performed pilgrimage and visitation. ${ }^{147}$ Such depictions include photographs and stereoscopic views that could transport the holy places to faraway locations and act as surrogates for travel, without the need for physical movement. ${ }^{148}$

Images of the Ka'ba and Mecca could convert everyday spaces into sacred places for worship. A number of early twentieth-century reverse glass paintings attest to such a transformation (fig. 26). ${ }^{149}$ Malik Aksel has noted that such panels (sing. levha) were used in domestic spaces to mark the qibla direction and invoke the daily prayer. ${ }^{150}$ As in figure 26 , the following poem was inscribed in multiple qibla panels with minor variations: "Oh visitor! Perform your prayer, qibla is this direction / Here is the basin, here is the ewer, here is the towel [hanging] on the rope" (Ey müsāfir! Kıl namāzıñ ḳıble bu cānibdedir / İşte leğen, işte ibrīk, işte peşkīr iptedir). Through text and imagery, this levha sacralizes space and calls upon the worshipper to perform ritual ablution and prayer. It illustrates two towels hanging between two flag posts along with the Kacba, a bird calligram, a pair of sandals, a ewer, and a basin. ${ }^{151}$ The latter three 


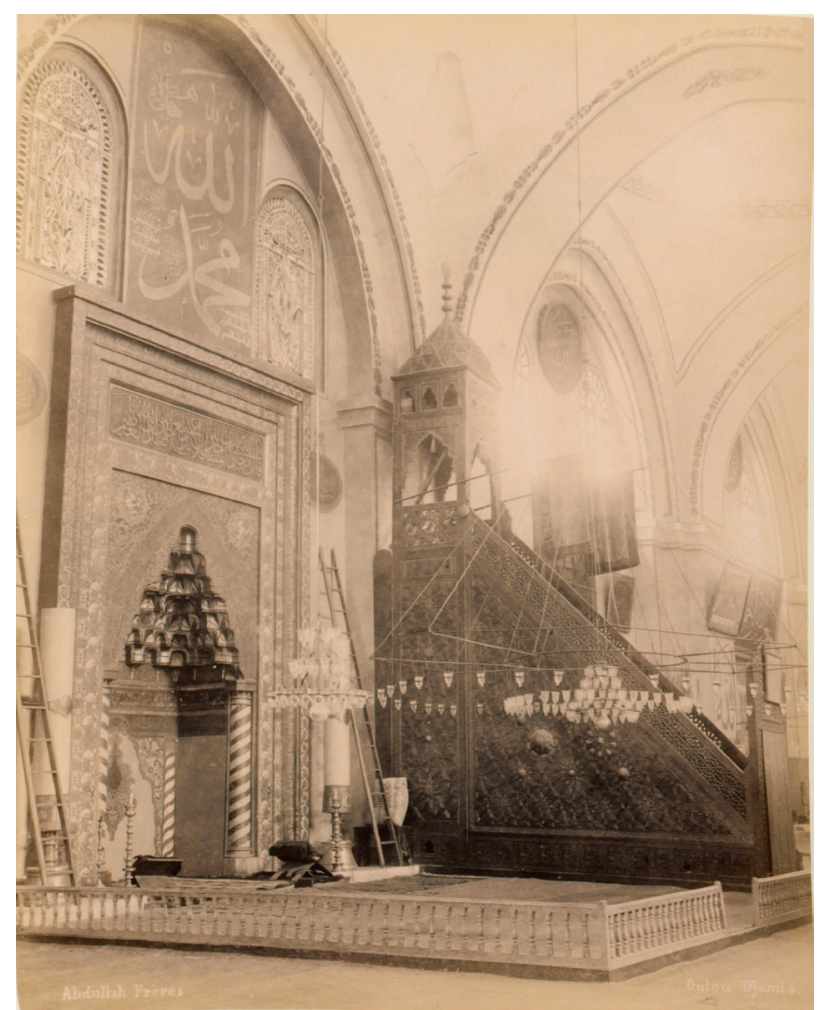

Fig. 27. Bursa Great Mosque. Abdullah Frères, late nineteenth century, $27 \times 20 \mathrm{~cm}$. Istanbul University Library, Rare Works Collection, no. 9o814/45. (İstanbul Üniversitesi Kütüphanesi)

images also recall the belongings (muhallefāt) of the Prophet that are frequently depicted in a popular prayer book entitled the En'ām-ı Şerîf and are sometimes integrated into the Dalā'il al-Khayrät. ${ }^{152}$ Even though the original location of the Fatih Mosque painting remains unknown, one might expect that it also transformed the space in which it was initially placed by objectifying the abstract notion of the qibla and creating a substitutive picture act. ${ }^{153}$

A number of objects associated with the Ka'ba can also be found in the qibla direction. For instance, in the Bursa Great Mosque, a curtain of the Ka ba door (sitāra) is currently located in a glass case on the left-hand side of the mihrab, whereas a late-Ottoman painting of Mecca is hanging on the right. Although barely visible behind two banners emerging from the minbar, the sitāra can be seen in its former place in a late-nineteenth-century photograph by the Abdullah Frères (fig. 27). Here, the Mamluk sitära, dated 922 (1516), hangs between the minbar and the Mecca painting. ${ }^{154}$ Furthermore, in the Sokollu Mehmed Pasha Mosque in Istanbul, three pieces of the black stone (al-hajar al-aswad) are oriented towards the qibla, whereas the fourth one is placed in the opposite direction. One of these pieces is fixed above the mihrab, two of them are attached to the minbar, and the last one is placed at the entrance to the prayer hall. ${ }^{155}$ This arrangement is not surprising, as the mihrab wall defines an esteemed space in the mosque interior and the architectural placement of traces from the Ka'ba tend to adhere to the qibla decorum. ${ }^{156}$

\section{CONCLUSION}

Mecca, Medina, and other cities of the Islamic world were connected with the flow of pilgrims, endowments, goods, and images, as well as religious and political ideologies. Motivated by caliphal and regal authority, the Ottomans controlled the mobilization of people, institutions, commodities, knowledge, and technology. Nevertheless, they did not have absolute power over these elements. The Fatih Mosque painting shows how people, photographs, images, and therefore places were on the move in nineteenth-century Ottoman lands and beyond. Early photographs of the Haramayn proliferated and circulated around the globe via international exhibitions, albums, books, lantern slides, and postcards in various centers such as Cairo, Istanbul, Leiden, Leipzig, Philadelphia, Stuttgart, and Venice. This reservoir of printed images and photographs helped Mi`marzade craft his painting.

Snouck Hurgronje, 'Abd al-Ghaffar, Sadiq Bey, and the other member of the military committee produced works that found their way into the collections of an Ottoman sultan and a Dutch scholar. These photographs traveled not only in their original format but also as prints, lantern slides, and paintings. On qibla walls and in prayer books and rugs, photographic images sustained ongoing traditions that had formerly utilized other modes of representation. They functioned in different ways each time they were reproduced and handled by a different artist or user. Among their many functions, they addressed ethnographic and architectural curiosity and pious yearning, mediated imagination and remembrance, and served political and religious 
ideologies, personal ambitions, and commercial pursuits.

The albums and single photographs presented here highlight the malleability and flexibility of photography as a medium. Similar to photographs of other important sites, photographs of Mecca and Medina had enormous potential to circulate and be reproduced in many creative ways. Photographs taken by the early photographers of the Hijaz reached distant places, persons, and collections via transregional networks woven by colonial efforts and imperial endeavors. Even though single photographs or albums were restricted to a limited audience (e.g., the Yıldız Albums), a translation to other formats and media (e.g., collotypes, lithographs, and lantern slides) allowed the mobilization of holy sites in various scales of reproduction, thereby enabling a broader access to images worldwide. When produced as a canvas painting or a prayer rug, such images complicated artistic and reception processes. When placed in a mosque space in particular, images of Mecca and Medina were oriented towards the qibla, visually directing their pious viewers to imagine themselves both spiritually and spatially in Islam's two holiest sites.

\section{University of Vienna}

\section{NOTES}

Author's note: This article developed from a paper I presented at the $104^{\text {th }}$ Annual Conference of the College Art Association (2016) and a chapter of my dissertation (2018). I continued my research and expanded the work while I was hosted by the Museum für Islamische Kunst in Berlin as a fellow of Connecting Art Histories in the Museum (2018-19), a joint research project of the Kunsthistorisches Institut in Florenz-Max-Planck-Institut and the Staatliche Museen zu Berlin-Stiftung Preußischer Kulturbesitz. I am grateful to these institutions for providing me with a position that enabled me to work on my own project. I also would like to thank Wolf-Dieter Lemke, Helmfried Luers, Ulrich Marzolph, Nancy Micklewright, Mary Roberts, Nazlı Vatansever, and Gökhun Yilmaz for their help with the sources used in this article. Furthermore, I am indebted to Lauren Nicole Davis, Christiane Gruber, Nina Macaraig, and Jan Just Witkam, as well as Gülru Necipoğlu, Maria J. Metzler, and the anonymous Muqarnas reviewer for their feedback on different drafts of this article.

1. Filiz Çağman, Kat' : Cut Paper Works and Artists in the Ottoman World (Istanbul: Aygaz, 2016), 257-67; Ashley Dimmig, "Fabricating a New Image: Imperial Tents in the Late Ottoman Empire," International Journal of Islamic Archi- tecture 3 (2014): 351-56; Mary Roberts, "The Limits of Circumscription," in Photography's Orientalism: New Essays on Colonial Representation, ed. Ali Behdad and Luke Gartlan (Los Angeles: Getty Research Institute, 2013), 53-74; Hülya Bilgi and İdil Zanbak, Skill of the Hand, Delight of the Eye: Ottoman Embroideries in the Sadberk Hanım Museum Collection (Istanbul: Sadberk Hanım Museum, 2012), 39-55, 320-33, cat. 134-39; Günsel Renda, "Ottoman Painting and Sculpture," in Ottoman Civilization, ed. Halil İnalcık and Günsel Renda (Istanbul: Kültür Bakanlığı Yayınları, 2002), 935-47; The Sultan's Portrait: Picturing the House of Osman (Istanbul: İş Bank, 200o), cat. 131-88; Zeynep Çelik, Remaking of Istanbul: Portrait of an Ottoman City in the Nineteenth Century (Berkeley: University of California Press, 1993), 126-54; Zeynep Çelik, Displaying the Orient: Architecture of Islam at Nineteenth-Century World's Fairs (Berkeley: University of California Press, 1992), 95-137; and Rüçhan Arık, Batılılaşma Dönemi Anadolu Tasvir Sanatı (Ankara: Türkiye İş Bankası Kültür Yayınları, 1976), 99-118.

2. For the sources and circulation of two eighteenth-century Mecca paintings (canvas and lacquer), see Deniz Beyazit, "Defining Ottoman Realism in the Uppsala Mecca Painting," Muqarnas 37 (2020): 209-45; Mehmet Tütüncü, "The Uppsala Mecca Painting: A New Source for the Cultural Topography and Historiography for Mecca," in Hajj: Global Interactions through Pilgrimage, ed. Luitgard Mols and Marjo Buitelaar (Leiden: Sidestone Press, 2015), 137-62; and Anton Schweizer and Avinoam Shalem, "Translating Visions: A Japanese Lacquer Plaque of the Haram of Mecca in the L.A. Mayer Memorial Museum, Jerusalem," Ars Orientalis 39 (2010): 148-73.

3. For mobility, portability, and translation, see Elisabeth A. Fraser, ed., The Mobility of People and Things in the Early Mediterranean: The Art of Travel (New York: Routledge, 2019); Avinoam Shalem, "The Poetics of Portability," in Histories of Ornament: From Global to Local, ed. Gülru Necipoğlu and Alina Payne (Princeton, NJ: Princeton University Press, 2016), 250-61; Michèle Hannoosh, "Practices of Photography: Circulation and Mobility in the Nineteenth-Century Mediterranean," History of Photography 40 (2016): 3-27; Christiane Gruber, "Islamic Architecture on the Move," International Journal of Islamic Architecture 3 (2014): 241-64; Heather E. Grossman and Alicia Walker, eds., Mechanisms of Exchange: Transmission in Medieval Art and Architecture of the Mediterranean, ca. 1000-1500 (Leiden: Brill, 2013); Anna Contadini and Claire Norton, eds., The Renaissance and the Ottoman World (Farnham: Ashgate, 2013); Nebahat Avcıoğlu and Finbarr Barry Flood, eds., "Globalizing Cultures: Art and Mobility in the Eighteenth Century," special issue, Ars Orientalis 39 (2010); Catarina Schmidt Arcangeli and Gerhard Wolf, eds., Islamic Artefacts in the Mediterranean World: Trade, Gift Exchange and Artistic Transfer (Venedig: Marsilio, 2010); Finbarr Barry Flood, Objects of Translation: Material Culture and Medieval "Hindu-Muslim" Encounters (Princeton, NJ: Princeton University Press, 20o9); and Eva R. Hoffman, "Pathways 
of Portability: Islamic and Christian Interchange from the Tenth to the Twelfth Century," Art History 24 (2001): 17-50. 4. Mimi Sheller and John Urry, "The New Mobilities Paradigm," Environment and Planning 38 (2006): 209-12; and John Urry, Mobilities (Cambridge, UK: Polity Press, 2007), 3-6. See also John Urry and Jonas Larsen, The Tourist Gaze o.3 (London: SAGE Publications, 2011), 155-88.

5. Photography has played an important role in many artists' creative process. See Dominique de Font-Réaulx, Painting and Photography 1839-1914, trans. David Radzinowicz (Paris: Flammarion, 2012), 263-65. Three major exhibitions have built upon European artists' response to photography and their exploration of the medium's capacities. For the exhibition catalogues, see Erika Billeter, ed., Malerei und Photographie in Dialog, von 1840 bis heute (Bern: Benteli Verlag, 1977); Elizabeth W. Easton, ed., Snapshot: Painters and Photography, Bonnard to Vuillard (New Haven, CT: Yale University Press, 2012); and Dorothy Kosinski, ed., The Artist and the Camera:Degas to Picasso (Dallas: Dallas Museum of Art, 1999).

6. For artists' collections of photographs, see de Font-Réaulx, Painting and Photography 1839-1914, 244-95.

7. Quadrillage is a method of transferring an image onto another surface by using a square grid. Photo-peinture is a method of fixing the photographic image on canvas by means of a sciopticon and a photosensitive emulsion. Ulrich Pohlmann, "Another Nature; or, Arsenal of Memory: Photography as Study Aid, 1850-1900," in Kosinski, Artist and the Camera, $55^{-} 5^{2}$.

8. Clément Chéroux, "A Sense of Context: Amateur Photography in the Late Nineteenth Century," in Easton, Snapshot, 44.

9. David J. Roxburgh, "Painting after Photography in 19thCentury Iran," in Technologies of the Image, ed. David J. Roxburgh and Mary McWilliams (Cambridge, MA: Harvard Art Museums, 2017), 109-11, 119. See also David J. Roxburgh, "Troubles with Perspective: Case Studies in Picture-Making from Qajar Iran," in Art History in the Wake of the Global Turn, ed. Jill H. Casid and Aruna D'Souza (New Haven, CT: Yale University Press, 2014), 112-14.

10. Ahmet Ersoy, "The Sultan and His Tribe: Documenting Ottoman Roots in the Abdülhamid II Photographic Albums," in Ottoman Arcadia: The Hamidian Expedition to the Land of Tribal Roots (1886), ed. Bahattin Öztuncay and Özge Ertem (Istanbul: Koç University Research Center for Anatolian Civilizations, 2018), 33, 38; and Ahmet Ersoy, "Ottomans and the Kodak Galaxy: Archiving Everyday Life and Historical Space in Ottoman Illustrated Journals," History of Photography 40 (2016): 330-57, at 334, 341.

11. For instance, see Jay David Bolter and Richard Grusin, Remediation: Understanding New Media (Cambridge, MA: MIT Press, 200o); and Jussi Parikka, What Is Media Archaeology? (Cambridge, UK: Polity Press, 2016).

12. For traveling concepts across different disciplines and their changing meanings, see Mieke Bal, Travelling Concepts in the Humanities: A Rough Guide (Toronto: University of Toronto Press, 2002), 24.
13. Bolter and Grusin define immediacy as the disappearance and dissolution of a medium, which "leaves us in the presence of the thing represented" (Bolter and Grusin, Remediation, 6 ). They argue that the immediacy created by linear perspective should not be considered universal (ibid., 21-24). In Islamic art, however, there are other modes of representation (e.g., multi- and paraline views) that also promise immediacy.

14. Berin Gölönü, "Images with a Second Life: Photographs of the Hüdāvendigar Province That Became Landscape Paintings," in Öztuncay and Ertem, Ottoman Arcadia, 107-19; Edhem Eldem, "Photography in the Service of Art," in Camera Ottomana, ed. Zeynep Çelik and Edhem Eldem (Istanbul: Koç University Press, 2015), 220-21; Pelin Şahin Tekinalp, "Links between Painting and Photography in Nineteenth-Century Turkey," Historiography of Photography 34 (2010): 291-99; Semra Germaner and Zeynep İnankur, Constantinople and the Orientalists (Istanbul: Işbank, 2002), 288-99; Stefan Weber, "Images of Imagined Worlds: Self-Image and Worldview in Late Ottoman Wall Paintings of Damascus," in The Empire in the City: Arab Provincial Capitals in the Late Ottoman Empire, ed. Jens Hanssen, Thomas Philipp, and Stefan Weber (Würzburg: Ergon in Kommission, 2002), 158; Günsel Renda, "Painted Decoration in 19th Century Ottoman Houses: Damascene Connection," in Actes du Ier Congrès International sur Corpus d'Archéologie Ottomane, 14-17 May 1996 (Zaghouan, Tunisia: Institut national du patrimoine, 1997), 96; Adnan Çoker, "Fotoğraftan Resim ve Darüşşafakalı Ressamlar," Yeni Boyut 9 (1995): 4-12; Mustafa Cezar, Sanatta Batı'ya Açılış ve Osman Hamdi, vol. 1 (Istanbul: Erol Kerim Aksoy Kültür, Eğitim, Spor ve Sağlık Vakfı Yayınları, 1995), 355-58; Semra Germaner and Zeynep İnankur, Orientalism and Turkey (Istanbul: The Turkish Cultural Service Foundation, 1989), 119-20; and Turan Erol, "Painting in Turkey in the Nineteenth and Early Twentieth Century," in A History of Turkish Painting, ed. Günsel Renda et al. (Seattle: University of Washington Press, 1988), 104.

15. For a study on the travel of images across lithography, painting, and photography, see Wolf-Dieter Lemke, "Orient-Bilder/Bilder-Orient: Imagination und visuelle Erschließung. Plädoyer für einen integrativen Ansatz," in Hoşsohbet: Erika Glassen zu Ehren, Istanbuler Texte und Studien 25, ed. Börte Sagaster et al. (Würzburg: Ergon Verlag, 2016), 75, 8o.

16. Sabiha Göloğlu, "Depicting the Holy: Representations of Mecca, Medina, and Jerusalem in the Late Ottoman Empire" (PhD diss., Koç University, 2018), 210-17, 450-53, figs. 136-43.

17. El-Hac Hüseyin Vassaf, Hicaz Hatırası, ed. Mehmet Akkuş (Istanbul: Kubbealtı, 2011).

18. Smaller numbers of early photographs of the Haramayn can also be found in private collections and institutions such as the Getty Research Institute in Los Angeles, the Victoria and Albert Museum and the Royal Geographical Society in London, the Institut de France in Paris, the Reiss-Engelhorn Museum in Mannheim, the Egyptian Geographical Society 
and the Rare Books and Special Collections Library of the American University in Cairo, the King Abdulaziz Foundation for Research and Archives in Riyadh, and the Library of the Masjid al-Haram in Mecca.

19. The photographs by Christiaan Snouck Hurgronje and those in Dutch collections have received special emphasis in the scholarship of Arnoud Vrolijk, Durkje van der Wal, Dirry Oostdam, and Jan Just Witkam. See Dirry Oostdam and Jan Just Witkam, West Arabian Encounters: Fifty Years of Dutch-Arabian Relations in Images (1885-1935) (Leiden: Leiden University Library, 2004); Carel van Leeuwen, Dirry Oostdam, and Steven Vink, Dutch Envoys in Arabia 1880-1950: Photographic Impressions (Amsterdam: KIT Publishers, 2011); Durkje van der Wal, Christiaan Snouck Hurgronje: The First Western Photographer in Mecca, 18841885 (Amsterdam: Manfred \& Hanna Heiting Fund, Rijksmuseum, 2011); Arnoud Vrolijk, "An Early Photograph of the Egyptian Mahmal in Mecca," in The Hajj: Collected Essays, ed. Venetia Porter and Liana Saif (London: British Museum, 2013), 206-13; and Arnoud Vrolijk, "Appearances Belie: A Mecca Centered World Map and a Snouck Hurgronje Photograph from the Leiden University Collections," in Mols and Buitelaar, Hajj, 213-27.

20. William Facey and Gillian Grant, Saudi Arabia by the First Photographers (London: Stacey International, 1996); Henry Laurens, Photographies d'Arabie, Hedjaz, 1907-1917 (Paris: Institut du monde arabe, 1999); Mehmet Bahadır Dördüncü, Mecca-Medina: The Yıldız Albums of Sultan Abdülhamid II (Somerset, NJ: Light, 20o6); Alfried Wieczorek, Michael Tellenbach, and Claude W. Sui, eds., To the Holy Lands: Pilgrimage Centres from Mecca and Medina to Jerusalem: Photographs of the $19^{\text {th }}$ Century from the Collections of the Reiss-Engelhorn Museums, Mannheim (Munich: Prestel, 2008); Anees Bashir Chaudhry, Medeniyet Yädigārlart: Mekke-i Mükerreme, Medine-i Münevvere, Taif (1967-1984) / Views into the Architectural Aspects of Makkah, Madinah \& Taif, ed. Emira Bayraktar and İbrahim Coşkun (Istanbul: Çamlıca Basım Yayın, 2011); and Halit Eren, Salih Sadawi, and Zeynep Dur, eds., Makka al-Mukarrama and al-Madina al-Munawwara in Photographs from the Ottoman Period / Osmanlı Dönemi Fotoğraflarıyla Haremeyn / Suwar al-Haramayn al-Sharīfayn fì al-'Ahd al-'Uthmānī (Istanbul: IRCICA, 2O13).

21. Badr El-Hage, Saudi Arabia: Caught in Time, 1861-1939 (Reading: Garnet Publishing, 1997); Claude W. Sui, "Pilgrimages to the Holy Sites of Islam and Early Photography," in Wieczorek, Tellenbach, and Sui, To the Holy Lands, 40-63; and Claude W. Sui, "Early Photography of the Holy Sites of Islam in the Arabian Peninsula," in The Indigenous Lens? Early Photography in the Near and Middle East, ed. Markus Ritter and Staci G. Scheiwiller (Berlin: De Gruyter, 2018), 111-43; Stephen Sheehi, Arab Imago: Social History of Portrait Photography, 1860-1910 (Princeton, NJ: Princeton University Press, 2016); and Meraj Nawab Mirza and Abdullah Saleh Shawoosh, The Illustrated Atlas of Makkah and the Holy Environs: From the $11^{\text {th }}$ Century to the Present Day (Mecca: The Center of Makkah History, 2011). See also Fred- erick H. S. Allen and Carney E. S. Gavin, Mecca: The First Photographs (Cambridge, MA: Harvard Semitic Museum, 1981); Carney E. S. Gavin, "Messengers from Mecca: Photography and Social Studies in Light from Ancient Lands," in The Invention of Photography and Its Impact on Learning: Photographs from Harvard University and Radcliffe College and from the Collection of Harrison D. Horblit, ed. Louise Todd Ambler and Melissa Banta (Cambridge, MA: Harvard University Library, 1989), 48-61; and Ali S. Asani and Carney E. S. Gavin, "Through the Lens of Mirza of Delhi: The Debbas Album of Early-Twentieth-Century Photographs of Pilgrimage Sites in Mecca and Medina," Muqarnas 15 (1998): 178-99.

22. There are also other publications that focus on the works of later photographers and photography studios, such as H.A. Mirza and Sons, Muhammad 'Ali Effendi Sa'udi, Mahmoud Arab Girly, and Ibrahim Rif'at Pasha. See Farid Kioumgi and Robert Graham, A Photographer on the Hajj: The Travels of Muhammad 'Ali Effendi Sa'udi (1904/1908) (Cairo: American University in Cairo Press, 20o9), ix-xviii; Sheehi, Arab Imago, 163-92; Asani and Gavin, "Through the Lens of Mirza of Delhi," 178-99; and Mirza and Shawoosh, Illustrated Atlas of Makkah, 107-50. See also the reference to two Ottoman photographers (Ahmed Hamdi Muzaffer and Miralay Münir) in Eren, Sadawi, and Dur, Makka alMukarrama and al-Madina al-Munawwara, 126-30.

23. An important connection "between the history of photography and Europe's knowledge about the Middle East has existed since the invention of the daguerreotype" in 1839 (Ali Behdad and Luke Gartlan, "Introduction," in Photography's Orientalism, 1).

24. Wieczorek, Tellenbach, and Sui, To the Holy Lands; Colin Osman, Jerusalem: Caught in Time (Reading: Garnet Publishing, 1999); Issam Nassar, Photographing Jerusalem: The Image of the City in Nineteenth Century Photography (Boulder, CO: East European Monographs, 1997); and Abigail Solomon-Godeau, "A Photographer in Jerusalem, 1885: Auguste Salzmann and His Times," October 18 (1981): 90-107.

25. Sui, "Pilgrimages to the Holy Sites," 45.

26. By the mid-nineteenth century, a large number of Muslim pilgrims arrived from European colonies all over the world, and their travel across colonial territories was regulated by European powers. The British, Dutch, French, and Italian consulates in Jidda controlled pilgrimage traffic. European powers "issued passports, visas, and health certificates to their subjects, and then transported them to the Hijaz" (Michael Wolfe, One Thousand Roads to Mecca: Ten Centuries of Travelers Writing about the Muslim Pilgrimage [New York: Grove Press, 1997], 192).

27. For studies on the materiality and lives of objects and images, see Elizabeth Edwards and Janice Hart, eds., Photographs Objects Histories: On the Materiality of Images (London: Routledge, 2004); and Arjun Appadurai, ed., The Social Life of Things: Commodities in Cultural Perspective (Cambridge, UK: Cambridge University Press, 1986). 
28. For "multiple mobilities" including those of places, see Sheller and Urry, "The New Mobilities Paradigm," 212-14.

29. For a framework of "geopiety" based on the geographical survey in Jerusalem and the Sinai Peninsula conducted by the British authorities, see Kathleen Stewart Howe, "Mapping a Sacred Geography: Photographic Surveys by the Royal Engineers in the Holy Land, 1864-68," in Picturing Place: Photography and the Geographical Imagination, ed. Joan M. Schwartz and James R. Ryan (London: I.B. Tauris, 2003), 226-42. For a framework of "geotheology" in the context of Palestine's spatial character, see Tarif Khalidi, "Space, Holiness, and Time: Palestine in the Classical Arab Centuries," in Studies in Arab History: The Antonious Lectures 1977-87, ed. Derek Hopwood (London: Palgrave Macmillan UK, 1990), 165-73. For definitions of "geopiety," "georeligion," and "geotheology," see John Kirtland Wright, "Notes on Early American Geopiety," in Human Nature in Geography: Fourteen Papers 1925-1965 (Cambridge, MA: Harvard University Press, 1966), 250-85.

3o. Bolter and Grusin define a medium as "that which remediates," and remediation as "the representation of one medium in another" (Bolter and Grusin, Remediation, $45,65)$. This suggests that the previous medium of painting subsumes photography; however, there are several instances where they mutually coexist, as in the Fatih Mosque painting.

31. An oral report suggests that Mi'marzade gifted the painting to his father-in-law, Mustafa Sabri Efendi, and then the painting changed hands several times until it came to the Fatih Mosque. Even though the authenticity of this anecdote is questionable, it hints that such paintings might have been initially destined for domestic spaces. Fatih Tığlı, "Sultan Ahmet Camii'ndeki Harem-i Şerif Tablosu ve Ressamının İlginç Hikayesi," İsmek El Sanatları Dergisi 17 (2014): 117-18.

32. The painting was recently restored by a group of conservators from the Conservation and Restoration Workshop of the Presidency of the Republic of Turkey and the Rijksmuseum in Amsterdam (2013-14). For details of the restoration project, see Nienke Woltman, Lauran Homer, and Willen de Ridder, "Fatih Mosque Painting Restored," The Picture Restorer 46 (2015): 19-30. For a Turkish version of the article, see Nienke Woltman and Lauran Homer, "Mimarzāde Mehmed Ali Bey'in Fatih Camii'ndeki Tablosu ve Zorlu Restorasyonu," Milli Saraylar 14 (2015): 174-75, 178-91.

33. Here, I have used the translation by M. A. S. Abdel Haleem, The Quran (Oxford: Oxford University Press, 2005), 312.

34. In the Islamic calendar, the night of the twenty-seventh of Ramadan (Laylat al-Qadr or Kadir Gecesi) is celebrated as the night when the Qur'an began to be revealed to the Prophet Muhammad. It was customary for calligraphers to finalize the copying of various manuscripts (e.g., Qur'an copies) on such important dates.

35. If the oral report that Mi'marzade gifted the painting to Mustafa Sabri Efendi is true, then these covered lines might be dedicatory. For this account, see Tığll, "Sultan Ahmet Camii'ndeki Harem-i Şerif Tablosu," 118.

36. According to İbnülemin Mahmud Kemal İnal, Muhammed 'Ali Efendi started working as a scribe at the Secretarial Office of the Shaykh al-Islam in 1909 and graduated from the Academy of Fine Arts in 1912. İbnülemin Mahmud Kemal İnal, Son Hattatlar (Istanbul: Maarif Basımevi, 1955), 576-8o. The information that Inal provides does not confirm the inscription of the painting, as Mi'marzade was not yet an architect nor a Meşihat scribe in 1905. Therefore, one must doubt either his biographical information or the painting's inscription.

37. For Micmarzade's Art Nouveau illumination of a diploma/ certificate (icāzet), see M. Baha Tanman, ed., Ekrem Hakkı Ayverdi 1899-1984: Mimarlık Tarihçisi, Restoratör, Koleksiyoner (Istanbul: İstanbul Araştırmaları Enstitüsü, 2014), 368-69. For his headpieces for Beyānü'l-Hakk magazine, see İnal, Son Hattatlar, 578-79. For his calligraphy in the Bolu Yıldırım Bayezid Mosque, see Tığlı, "Sultan Ahmet Camii'ndeki Harem-i Şerif Tablosu," 116-19.

38. Selman Soydemir and Tunahan Kanıcı, "Şehirleri Bağlayan Tablo," Yedi Kıta 9o (2016): 50-53; Coşkun Yılmaz, "İstanbul'dan Harameyn'e Bakış: Bir Resmin Hikayesi," Üsküdar Kültür Sanat ve Medeniyet Dergisi 2 (2016): 5-8; Ömer Faruk Şerifoğlu, "Mimarzāde Mehmed Ali Bey," Milli Saraylar 14 (2015): 176-77; Beşir Ayvazoğlu, "Unutulmuş Bir Ressam Gün Işığına Çıkarıldı," Türk Edebiyatı 48o (2013): 68-72; and Zübeyde Cihan Özsayıner, "The Last Director of the Evkaf-i İslamiyye Museum, Mimarzade Muhammed Ali, Calligraphist and Painter," The $15^{\text {th }}$ International Congress of Turkish Art, Naples, September 14-16, 2015.

39. The Uppsala painting (UU 2372) has received considerable scholarly attention recently. A symposium (The Image of Mecca, Uppsala, May 5, 2014) and a workshop (Aspects on Early Representations of Mecca and the Ka'ba in Ottoman Art, Istanbul, April 20-21, 2017) were held towards a book project about the Uppsala painting. See also Beyazit, "Defining Ottoman Realism," 209-45; and Tütüncü, "Uppsala Mecca Painting," 137-62.

40. For traveling images and photocollage, see Anna Dahlgren, Travelling Images: Looking Across the Borderlands of Art, Media, and Visual Culture (Manchester: Manchester University Press, 2019).

41. İnal, Son Hattatlar, 577.

42. For copies of the photograph with different levels of brightness and contrast, see 9o819/3 and 90836/10-13 in the Ylldız Albums of the Istanbul University Library.

43. For a comprehensive study on the Ylldız Palace, see Deniz Türker, "Ottoman Victoriana: Nineteenth-Century Sultans and the Making of a Palace, 1795-1909" (PhD diss., Harvard University, 2016). On the Yıldız Mosque and the changing views about its architect, see Selman Can, "Yıldız Camii," TDV İslām Ansiklopedisi, vol. 43 (Istanbul: Türkiye Diyanet Vakfl, 2013): 540-41; and Pars Tuğlacı, Osmanlı Mimarlı̆̆ında Balyan Ailesinin Rolü (Istanbul: Yeni Çı̆̆ır, 
1993), 268-73. See also Özge Yıldız, "The Star Turn: The Yıldız Hamidiye Mosque," Cornucopia $5^{2}$ (2015): 57-61. Ahmet Ersoy, Architecture and the Late Ottoman Historical Imaginary: Reconfiguring the Architectural Past in a Modernizing Empire (Farnham: Ashgate, 2015), 213.

45. Among these publications are: Owen Jones and Jules Goury, Plans, Elevations, Sections, and Details of the Alhambra, 2 vols. (London: O. Jones, 1842-45); Owen Jones, Grammar of Ornament (London: Day \& Son, 1856); and Zanth Ludwig, Die Wilhelma: Maurische Villa seiner Majestät des Königes Wilhelm von Württemberg (Stuttgart: Eigenthum des Verfassers, $1855^{-56}$ ). For references to these works, see Turgut Saner and Bilge Ar, "Beylerbeyi Sarayı Dekorasyonunda Owen Jones'un Yayınlarından Uyarlanmış Elhambra Desenleri," Milli Saraylar 17 (2019): 123-37; Turgut Saner, “19. Yüzyıl Osmanl Eklektisizminde Elhamra'nın Payı," in Osman Hamdi Bey ve Dönemi, ed. Zeynep Rona (Istanbul: Tarih Vakfi Yurt Yayınları, 1993), 134-45; and Filiz Yenişehirlioğlu, "Continuity and Change in Nineteenth Century Istanbul: Sultan Abdülaziz and the Beylerbeyi Palace," in Islamic Art in the 19th Century: Tradition, Innovation, and Eclecticism, ed. Doris Behrens-Abouseif and Stephen Vernoit (Leiden: Brill, 2006), 57-88.

46. For a thorough study on this script, see İrvin Cemil Schick, "The Revival of $K \bar{u} f \imath$ Script during the Reign of Sultan Abdülhamid II," in Calligraphy and Architecture in the Muslim World, ed. Mohammad Gharipur and İrvin Cemil Schick (Edinburgh: Edinburgh University Press, 2013), 119-38. For an example of Mi'marzade's Küfi calligraphy in the Bolu Yıldırım Bayezid Mosque, see Tığlı, "Sultan Ahmet Camii'ndeki Harem-i Şerif Tablosu," 116-19.

47. For the Hijaz Railway, see William Ochsenwald, The Hijaz Railroad (Charlottesville: University Press of Virginia, 1980); Said Öztürk, "Hicaz Demir Yolu," in Osmanlı Devleti'nin 700. Kuruluş Yıldönümünde Sultan II. Abdülhamid Dönemi Paneli (II) (Istanbul: Bilge Yayıncılık, 200o); M. Metin Hülagü, The Hejaz Railway: The Construction of a New Hope (New York: Blue Dome Press, 2010); and Murat Özyüksel, Hejaz Railway and the Ottoman Empire: Modernity, Industrialization, and the Ottoman Decline (London: I.B. Tauris, 2014). For a recent study on Ottoman Damascus and its connectivity, see Nir Shafir, "In an Ottoman Holy Land: The Hajj and the Road from Damascus, 1500-180o," History of Religions 6o (2020): $1-36$.

48. Peter H. Christensen, Germany and the Ottoman Railways: Art, Empire, and Infrastructure (New Haven, CT: Yale University Press, 2017), 16, 33-37; and Ersoy, "Ottomans and the Kodak Galaxy," 341-42.

49. Arık, Batılılaşma Dönemi Anadolu Tasvir Sanatı, 70; Günsel Renda, Batılılaşma Döneminde Türk Resim Sanatı (Ankara: Hacettepe Üniversitesi Yayınları, 1977), 16o; and Stefan Weber, "Images of Imagined Worlds," 168.

50. Klaus Kreiser, "Public Monuments in Turkey and Egypt, 1840-1916," Muqarnas 14 (1997): 103-17, at 110-12; and Mehmet Tütüncü, "Osmanlı Modernleşmesinin Anıtlara
Yansıması: Hayfa Hicaz Demiryolu ve Şam Telgraf Anıtları," in Osmanlı Dünyasında Kültürel Karşılaşmalar ve Sanat Dünyasına Yansımaları. Prof. Dr. Filiz Yenişehirlioğlu'na Armağan / Cultural Encounters in the Ottoman World and Their Artistic Reflections. In Honor of Prof. Dr. Filiz Yenişehirlioğlu, ed. Ayşe Pelin Şahin Tekinalp, Mehmet Fatih Müderrisoğlu, and Ünal Araç (Ankara: Hacettepe University, 2017), 246-5o.

51. David Simonowitz, "The Mobile Matrix: The Hijaz Railway as Ritual Space and Generator of Space," International Journal of Islamic Architecture 3 (2014): 303-40, at 326-27. Similarly, 'Abdülhamid II planned a prestige project for a short railway track and an imperial wagon operating on the grounds of the Ylldız Palace; however, this project was never realized (Türker, "Ottoman Victoriana," 34-38).

52. On geography in the late Ottoman education system, see Nuri Doğan, İlk ve Orta Dereceli Okul Ders Kitapları ve Sosyalleşme (1876-1918) (Istanbul: Bağlam Yayınları, 1994), 24-74; and Bayram Kodaman, Abdülhamid Dönemi Eğitim Sistemi (Ankara: Türk Tarih Kurumu, 1991), 57-162.

53. Benjamin C. Fortna, Imperial Classroom: Islam, the State, and Education in the Late Ottoman Empire (Oxford: Oxford University Press, 2002), 191. See also Benjamin C. Fortna, "Change in the School Maps of the Late Ottoman Empire," Imago Mundi 57 (2005): 24-25.

54. Zeynep Çelik, "Speaking Back to Orientalist Discourse at the World's Columbian Exposition," in Noble Dreams, Wicked Pleasures: Orientalism in America, 1870-1930, ed. Holly Edwards (Princeton, NJ: Princeton University Press, 2000), 89, fig. 18; and Tuba Çavdar Karatepe, "Yıldız Sarayı Kütüphanesi," TDVİslām Ansiklopedisi, vol. 43 (Istanbul: Türkiye Diyanet Vakfi, 2013): 544-45.

55. For more on the "Hamidian visual archive" and its expansion through the materials gathered during the Sögüt expedition, see Ersoy, "Sultan and His Tribe," 31-33; and Deniz Türker, "Every Image Is a Thought': Nineteenth-Century Gift Albums and the Hamidian Visual Archive," in Öztuncay and Ertem, Ottoman Arcadia, 65-67.

56. Another painting by Micmarzade is preserved in the Calligraphy Collection of National Palaces in Istanbul (Dolmabahçe Palace) that is explicitly dedicated to Abdülhamid II-this time expressed in panegyric verses and the Ottoman coat of arms (arma) with the sultan's imperial cypher (tuğra). The painting is dated to 15 Ramadan 1319 (December 26, 1901); however, like the Fatih Mosque painting, one must be suspicious of this information as well. Calligraphy is more dominant in this second painting, despite the merging maps, vignettes, and views of the planets, the globe, the Hijaz Railway, Mecca, Medina, Istanbul, the Yıldız Palace, the Yıldız Hamidiyye Mosque, and the Damascus Telegraph/Railway Monument. Here, Mi`marzade brought several images together in a collage and meticulously worked out their details. As a result, the Dolmabahçe painting surpasses the Fatih painting in its ideological emphasis but not in its religious tone. For a short essay on the Dolmabahçe 
painting, see Gökçe Demiray, "Mimarzāde Mehmed Ali'nin Eserinden II. Abdülhamid Dönemi Osmanlı Panoraması," Milli Saraylar 15 (2016): 16o-67.

57. For religious, political, and socio-economic aspects of sixteenth- and seventeenth-century Ottoman hegemony over the Haramayn, see Suraiya Faroqhi, Pilgrims and Sultans: The Hajj under the Ottomans 1517-1683 (London: I.B. Tauris, 1996).

58. Quoted in Selim Deringil, The Well-Protected Domains: Ideology and the Legitimation of Power in the Ottoman Empire 1876-1909 (London: I.B. Tauris, 2004), 29, 108.

59. In an album of two engraved portraits of Selim III, the front doublure consists of a four-partite painting of Mecca, Medina, Jerusalem, and Istanbul and the back doublure bears one of the Bosphorus, the Dardanelles, Bursa, and Edirne. The sultan's portrait was painted by Kostantin Kapıdağlı and then engraved by Schiavonetti in London. Both of the four-partite panoramas are also attributed to Kostantin Kapıdağlı. See Günsel Renda, "Ressam Konstantin Kapıdağlı Hakkında Yeni Görüşler,” in 19. Yüzyıl İstanbul'unda Sanat Ortamı Sempozyumu Bildirileri, 14-15 Mart 1996 (Istanbul: Sanat Tarihi Derneği, 1996), 139-62.

6o. For more information on Ottoman maps and plans, see M. Pınar Emiralioğlu, Geographical Knowledge and Imperial Culture in the Early Modern Ottoman Empire (Burlington: Ashgate, 2014); IIffet Orbay, "İstanbul'a Bakış: Kitāb-i Bahriye Yazmalarında İstanbul Tasvirinin Ortaya Çıkışı ve Evrimi (16.-17. Yüzyll)," in Gelenek, Kimlik, Birleşim: Kültürel Kesişmeler ve Sanat - Günsel Renda'ya Armağan, ed. Zeynep Yasa Yaman and Serpil Bağcı (Ankara: Hacettepe Üniversitesi Edebiyat Fakültesi, 2011), 199-20; Çiğgdem Kafescioğlu, "Osmanlı Şehir Tahayyülünün Görsel ve Edebi İzleri: Onaltıncı ve Onyedinci Yüzyıl Menzilname ve Seyahatnamelerinde Şehir İmgeleri," in Yasa Yaman and Serpil Bağcl, Gelenek, Kimlik, Birleşim, 139-5o; Kathryn Ann Ebel, "Representations of the Frontier in Ottoman Town Views of the Sixteenth Century," Imago Mundi 6o (2008): 1-22; Kathryn Ann Ebel, "Visual Sources for Urban History of the Ottoman Empire," Türk Araştırmaları Literatür Dergisi 3 (2005): 457-86; J. Michael Rogers, "Itineraries and Town Views in Ottoman Histories," in The History of Cartography, ed. J. B. Harley and David Woodward, vol. 2, book 1 (Chicago: University of Chicago Press, 1992), 228-53; Ahmet T. Karamustafa, "Military, Administrative, and Scholarly Maps and Plans," in Harley and Woodward, The History of Cartography, vol. 2, book 1, 210-15; and Gülru Necipoğlu, "Plans and Models in Fifteenth- and Sixteenth-Century Ottoman Architectural Practice," Society of Architectural Historians 45 (1986): 224-43.

61. J. B. Harley, "Maps, Knowledge, and Power," in The New Nature of Maps: Essays in the History of Cartography, ed. Paul Laxton (Baltimore: The Johns Hopkins University Press, 2002), 53, 57-58.

62. For two short entries about Sadiq Bey, see Nissan N. Perez, Focus East: Early Photography in the Near East (1839-1885) (New York: Harry N. Abrams, Inc., Publishers, 1988), 214-15; and Engin Özendes, Photography in the Ottoman Empire
1839-1923 (Istanbul: YEM Yayın, 2013), 183-85. Also see Maria Golia, Photography and Egypt (Cairo: American University in Cairo, 2010), 49-55; and Mounira Khemir, "The Orient in the Photographers' Mirror: From Constantinople to Mecca," in Orientalism: Delacroix to Klee, ed. Roger Benjamin (Sydney: The Art Gallery of New South Wales, 1998), 189-95, 231.

63. For the pamphlet, see Sotheby's, Travel, Atlases and Natural History, 4 June 1998 (London: Sotheby's, 1998), lot 328. I would like to thank Claude W. Sui and Oya Delahaye for providing me with the details of this catalogue. A sticker on the backside of one of Sadiq Bey's photographs can be found in the Victoria and Albert Museum (no. 2135-1924). A seal on the mount of one of Sadiq Bey's photograph can be found at the Getty Research Institute (Shapazian Collection, 2010.R.20, T 12).

64. Sadiq Bey published four books about his travels. Here, I have used a volume that reprints all four together: Muhammad Ṣadīq Bāshā, al-Riḥla al-Hijāziyya, ed. Muhammad Hammam Fakri (Beirut: Badr lil-Nashr wal-Tawzī', 1999), 47. The original publications are as follows: Muhammad Ṣadīq Pāshā, Nubdha fi istikshāf țarīq al-arż al-Hijāziyya min al-Wajh wa-Yanbu'al-Bahr ila al-Madina al-Nabawiyya (Cairo: Mațba' 'Umūm Arkān Harb, 1294/1877); Mash'al al-mahmal (Cairo: Mațba' Wadì al-Nīl, 1298/1881); Kawkab al-ḥajj fi safar al-maḥmal baḥaran wa-sīrahu barran (Cairo: Mațba' al-Amīriya, 1303/1886); and Dalïl al-hajj lil-wārid ila Makka wa-l-Madina min kull fajj (Cairo: Maṭba' al-Kubrā al-Amīriya, 1313/1896).

65. S Sadīq Bāshā, al-Riḥla al-Hijāziyya, 259. See also Mirza and Shawoosh, Illustrated Atlas of Makkah, 61. Two documents in the Republic of Turkey's Presidency State Archives relate to Sa'id Pasha's visit to Medina. The document dated 1 Jumada II 1277 (December 15, 186o) requests the assistance of the governor of Jidda and the emir of Mecca during Sacid Pasha's visit (A.\}MKT.MHM., Kutu: 204, Gömlek: 24 [noted as it appears in the online catalogue]). The document dated to 16 Ramadan 1277 (March 28, 1861) informs us about the completion of Sa 'id Pasha's visit (A.\}MKT.MHM., Kutu: 213, Gömlek: 45). These documents, however, do not refer to Sadiq Bey or anyone else in Sa'id Pasha's retinue.

66. See the pamphlets that advertised Sadiq Bey's photographic portfolios and the introduction of Sadiq Bey's fourth book, Dalīl al-Hajj: Sotheby's, Travel, Atlases and Natural History, 4June 1998, lot 328; and Ṣadīq Bāshā, al-Riḥla al-Hijāziyya, 259. Similarly, Auguste Salzmann received a gold medal for his panorama of Jerusalem at the Exposition Universelle in Paris (1855). Solomon-Godeau, "A Photographer in Jerusalem, 1885," 93-94.

67. The photograph of Medina, which is often dated to 1861 , exists in several copies (fig. 11). The Istanbul University Library (90770/4a-b) and Victoria and Albert Museum (2131-1924) copies are not fully cropped; therefore, they reveal the signature of Sadiq Bey and the date of Muharram 1298 (December 1880-January 1881) in the lower middle. If Sadiq Bey did not post-date the photograph he took in 1861, then the earliest photographs of Medina have not yet 
come to light. For copies of this photograph, see Dördüncü, The Yıldız Albums of Sultan Abdülhamid II, 118-19; Eren, Sadawi, and Dur, Makka Al-Mukarrama and Al-Madina AlMunawwara, 180-83; Wieczorek, Tellenbach, and Sui, To the Holy Lands, 133; Porter, Hajj, 78-79, fig. 47; and Sheehi, The Arab Imago, xix, fig. 1. The 1861 photograph of Medina, which sourced the lithograph and the woodcut of the city in Nubdha fi istikshäf țarīq al-arż al-Hijäziyya and Mash'al al-mahmal, must have been taken from a very similar angle as the 1881 photograph of the city.

68. In a photograph taken by the Ottoman committee, Sadiq Bey appeared within the frame, whereas in a photograph taken by Sadiq Bey, the Ottoman committee was captured. Mirza and Shawoosh, Illustrated Atlas of Makkah, 54-55, 70-75.

69. Eren, Sadawi, and Dur, Makka Al-Mukarrama and AlMadina Al-Munawwara, xli.

70. For earlier nineteenth-century drawings of the Masjid alNabawi and Medina as well as documents regarding the holy mosque's repairs, see Mustafa Güler, ed., Belgelerle Osmanlı Devrinde Hicaz: Medīne-i Münevvere-Cidde-SurreMuhtelif, vol. 2 (Istanbul: Çamlıca, 2008), 2-9, 66-67, 111-25, 168-71.

71. İUKK no. 92252 is a $1 / 2000$ scaled map of Mecca dated to Rabic I 1298 (February-March 1881). İÜK no. 92253 is a 1/1400o scaled map of Medina dated to Jumada I 1297 (April-May 1880). İ̈KK no. 92254 is a 1/50oo scaled map of Yanbu dated to Rabic II 1297 (March-April 188o). İ̈KK no. 92255 is a $1 / 16$ o scaled plan of Masjid al-Nabawi dated to Rabic II 1297 (March-April 188o). IÜKK no. 92256 is a 1/400 scaled plan of the Masjid al-Haram dated to Rabic II 1298 (March 1881). İÜK no. 92257 is a 1/50oo scaled map of Ta'if dated to Shawwal 1297 (September-October 1880). IÜK no. 92258 is a $1 / 300000$ scaled map of the Hijaz dated to 1301 (1883-84). İ̈K no. 92259 is another map of Medina this time scaled to $1 / 2000$ and dated to Jumada II 1297 (MayJune 1880). İÜK no. 9226o is a 1/300o scaled map of Jidda dated to Rabi' I 1298 (February-March 1881). IÜK no. 93679 is a $1 / 200$ scaled plan of the Masjid al-Haram's courtyard dated to 1301 (1883-84).

72. For instance, a plan of Masjid al-Nabawi was inserted in Nubdha fi istikshāf țarīq al-arż al-Hijäziyya and Kawkab al-hajj, and a plan of Masjid al-Haram was inserted in Kawkab al-hajj.

73. Șadīq Pāshā, Mash'al al-maḥmal, 3o. See also el-Hage, Saudi Arabia Caught in Time 1861-1939, 23-24. Here, el-Hage erroneously identifies the Masjid al-Haram and Medina photographs of Sadiq Bey published in David George Hogarth's The Penetration of Arabia (1904) as those of 'Ali Bey.

74. İ̈KK no. 92252 and IÜK no. 92256. For their reproductions, see Eren, Sadawi, and Dur, Makka Al-Mukarrama and AlMadina Al-Munawwara, 2-3.

75. The upper structures of the stations (maqāmāt) are partially documented in the plan, and their elevations are shown on the right-hand side of the drawing. Moreover, the legend on the left provides the names of the stations and other structures that are numbered in the plan.
76. İÜK T 4660 is a $1 / 20000$ scaled map of Mecca (also showing Mina, Muzdalifa, and 'Arafat) dated to 14 Jumada I 1305 (January 28, 1888). IÜK T 4659 is a repair report dated to 11 Rabi' II 1305 (December 27, 1887). For more information about the 'Ayn Zubayda water supply system, see Mustafa Güler, Osmanlı Devleti'nde Haremeyn Vakıfları (16. ve 17. Yüzyıllar) (Istanbul: Çamlıca, 2011), 79-83; and Süleyman Şefik Söylemezoğlu, Hicaz Seyahatnamesi (Istanbul: İz Yayıncilık, 2013), 144.

77. Five yearbooks of the Hijaz province were published in Mecca in 1301 (1884), 1303 (1886), 1305 (1888), 1306 (1889), and 1309 (1892). In the yearbook of 1301 (1884), Sadiq Bey is mentioned as a lieutenant colonel of the General Military Staff (Erkān-ı Harbiyye Kaymaḳāmı) and the head of the Military Building Commission in Mecca (Ebniye-i 'Askeriyye Komisyonu). In the yearbook of 1303 (1886), he is recorded as a colonel of the General Military Staff (Erkān-ı Harbiyye Mìralayı) and the head engineer of the State Building Commission (Ebniye-i Mìriyye İnşă at Komisyonu). Based on the 1881 Masjid al-Haram plan and the 1884 and 1886 yearbooks, one can follow the changes in Sadiq Bey's military rank over five years: major (biñbaşı), lieutenant colonel (ḳaymaḳām), and colonel (mīralay). Hicāz Vilāyeti Sālnāmesi (Mecca: Hicāz Vilāyet Maṭba'ası, 1301), 88; Hicāz Vilāyeti Sālnāmesi (Mecca: Hicāz Vilāyet Mațba'ası, 1303), 62, 64; and Selman Soydemir, Kemal Erkan, and Osman Doğan, Hicaz Vilāyet Salnamesi, H. 1303/M. 1886 (Istanbul: Çamlıca, 2008), 51-52.

78. For cartography at the service of imperialism, see James R. Ackerman, ed., The Imperial Map: Cartography and the Mastery of Empire (Chicago: University of Chicago Press, 20o9); and James R. Ackerman, ed., Decolonizing the Map: Cartography from Colony to Nation (Chicago: University of Chicago Press, 2017).

79. For instance, see John F. Keane, Six Months in Meccah: An Account of the Mohammedan Pilgrimage to Meccah (London: Tinsley Brothers, 1881); John F. Keane, My Journey to Medinah:Describing a Pilgrimage to Medinah (London: Tinsley Brothers, 1881); and Charles Montagu Doughty, Travels in Arabia Deserta (Cambridge: Cambridge University Press, 1888).

8o. Jan Just Witkam, "Christiaan Snouck Hurgronje: A Tour d'Horizon of His Life and Work," in Christiaan Snouck Hurgronje (1857-1936): Orientalist (Leiden: Leiden University Library, 2007), 12. See also James Henry Monahan, "Introduction," in Mekka in the Latter Part of the 19th Century: Daily Life, Customs and Learning of the Moslims of the EastIndian-Archipelago (Leiden: Brill, 1931), v.

81. Van der Wal, Christiaan Snouck Hurgronje, v.

82. According to Witkam, Snouck Hurgronje had to leave the city because the French consul in Jidda accused him of stealing an old inscription. Jan Just Witkam, "Fifty Years of Dutch-Arabian Relations in Images (1885-1935)," in West Arabian Encounters: Fifty Years of Dutch-Arabian Relations in Images (1885-1935), ed. Dirry Oostdam and Jan Just Witkam (Leiden: Leiden University Library, 2004), 10.

83. The first volume concerns the history of Mecca, whereas the second is on Meccan society. Christiaan Snouck Hurgronje, 
Mekka: Die Stadt und ihre Herren (Haag: Martinus Nijhoff, 1888); and Christiaan Snouck Hurgronje, Mekka: Aus dem heutigen Leben (Haag: Martinus Nijhoff, 1889). The English translation of the second volume was first published by Brill in 1931 under the title Mekka in the Latter Part of the $19^{\text {th }}$ Century. The second edition was published in 1970, and the third with an introduction by Jan Just Witkam in 2007. Here, I use the earliest edition for the body of text, Christiaan Snouck Hurgronje, Mekka in the Latter Part of the $19^{\text {th }}$ Century: Daily Life, Customs and Learning of the Moslims of the East-Indian-Archipelago, trans. James Henry Monahan (Leiden: Brill, 1931).

84. Christiaan Snouck Hurgronje, Bilder-Atlas (Haag: Martinus Nijhoff, 1888); and Snouck Hurgronje, Bilder aus Mekka (Leiden: Brill, 1889). For a selection of images from the Bilder-Atlas and Bilder aus Mekka, see Angelo Pesce, ed., Makkah a Hundred Years Ago or C. Snouck Hurgronje's Remarkable Albums (London: Immel Publishing, 1986).

85. Robert Irwin, "Journey to Mecca: A History," in Hajj:Journey to the Heart of Islam, ed. Venetia Porter (London: British Museum, 2012), 193.

86. Jan Just Witkam, "Introduction," in Mekka in the Latter Part of the $19^{\text {th }}$ Century: Daily Life, Customs and Learning of the Moslims of the East-Indian-Archipelago, trans. James Henry Monahan (Leiden: Brill, 2007), xv-xvi. See also Witkam, "Christiaan Snouck Hurgronje," 19, 28-31.

87. Snouck Hurgonje refers to Sadiq Bey's book in the context of circumcision among different tribes. Snouck Hurgronje, Mekka in the Latter Part of the 19th Century, $113 \mathrm{n}$.

88. Snouck Hurgronje, Bilder aus Mekka, n.p.

89. Oostdam and Witkam have suggested that Snouck Hurgronje erased 'Abd al-Ghaffar's captions and signatures from the plates for aesthetic reasons rather than authorship concerns. Oostdam and Witkam, West Arabian Encounters, 32. Sui has suggested another reason: to protect his provider from possible charges and keep their collaboration confidential. Sui, "Pilgrimages to the Holy Sites," 57; and "Early Photography of the Holy Sites," 132-33.

9o. For the correspondence in the Leiden University Libraries, see Or. 18.o97 S 32.1-7. For Jan Just Witkam's translations of the letters sent from 'Abd al-Ghaffar to Snouck Hurgronje, see Sui, "Pilgrimages to the Holy Sites," 58-6o; and Sui, "Early Photography of the Holy Sites," 134-38. See also Jan Just Witkam, Inventory of the Oriental Manuscripts of the Library of the University of Leiden, vol. 9 (Leiden: Ter Lugt Press, 2019), Or. 8952 A 1.

91. The lithographs in the Bilder-Atlas are of the Ka'ba covering and the ethnographic objects, but they also include those made after photographs of poor quality.

92. 'Abd al-Ghaffar studied with a British dentist serving the khedivial family. Șadīq Pāshā, Dalīl al-Hajj, 69. See also elHage, Saudi Arabia Caught in Time 1861-1939, 45-46; and Vrolijk, "An Early Photograph of the Egyptian Mahmal in Mecca," 209.

93. See Nurhan Atasoy, "Sultan Abdülhamid II's Photo-Collections in Istanbul," Journal of Turkish Studies 12 (1988): v-vi; and other articles in the same volume. See also Muhammad Isa Waley, "Images of the Ottoman Empire: The Photograph Albums Presented by Sultan Abdülhamid II," Electronic British Library Journal (1991): 113, accessed October 19, 2018, <http://www.bl.uk/eblj/1991articles/pdf/articleg.pdf>; and Bahattin Öztuncay and Özge Ertem, eds., Ottoman Arcadia. For a recent doctoral study on the Abdülhamid Albums, Elbise-i 'Osmāniyye, and other products of Ottoman photography, see Erin Hyde Nolan, "Ottomans Abroad: The Circulation and Translation of Nineteenth-Century Ottoman Photography" (PhD diss., Boston University, 2017).

94. These are Album 90543 (The Guesthouse in Mecca), Album 90743 (Mecca and Medina), Album 90744 (Mecca, Medina, and Ta'if), Album 90745 (Mecca, Medina, and Ta'if), Album 90746 (Mecca, Medina, and Ta'if), Album 90747 (Medina), Album 90748 (Mecca and Ta'if), Album 90749 (Yanbu and Jidda), Album 90770 (Mecca and Medina), Album 90789 (Mecca), and Album 90877 (Hamidiyye Cavalry Regiments).

95. For the reciprocal relationship between the Ottoman press and Abdülhamid II, see Ebru Boyar, "The Press and the Palace: The Two-Way Relationship between Abdülhamid II and the Press, 1876-19o8," Bulletin of SOAS 69 (2006): 417-32.

96. These photographs are preserved in a loose format in folders Or. 12.288 J, Or. 12.288 L, and Or. 26.367.

97. The four-part panorama of Mecca taken from Abu Qubays, the three-part panorama of 'Arafat where pilgrims perform the rite of standing ( $w u k \bar{u} f$ ), and the two-part panorama of Mina where pilgrims camp during the Hajj appear in both Bilder aus Mekka and Album 90789. The photograph of Muzdalifa, where pilgrims collect stones to throw at the three pillars (jamarāt) at Mina, is also shared between the two albums. In comparison with this photograph in the Ylldiz Album, one can see the retouches made on the photograph in Bilder aus Mekka. Hazy figures in the foreground and a vague camel caravan in the background are retouched to ensure that they appear more distinctly. The characteristic signature of 'Abd al-Ghaffar is again placed prominently in the lower middle of the photograph.

98. The caption on the photograph's mount (90770/6b) reads: "Medīne-i Münevvere haricinde Uhud Dağı ve Seyyidü'lŞühedā 'Amm-ı Resūl-i Ekrem Hamza bin 'Abdülmutțalib efendimiz ḥażretleriniñ merḳad-ı şerīfi manẓaraları.” For this photograph, see Dördüncü, The Yıldız Albums of Sultan Abdülhamid II, 122-23; and Eren, Sadawi, and Dur, Makka Al-Mukarrama and Al-Madina Al-Munawwara, 280-81.

99. It is possible to attribute the Mecca and Masjid al-Haram photographs to the $1880-81$ Ottoman military committee based on the presence of the qubbatayn (removed from the mosque courtyard in 1882-83) and the absence of the Hamidiyye Barracks (built in 1884-85) in panoramas and shots of the city and the mosque.

100. For photographs from Album 90877, see Dördüncü, The Yıldız Albums of Sultan Abdülhamid II, 49, 54-59, 133-34; 
and Eren, Sadawi, and Dur, Makka Al-Mukarrama and AlMadina Al-Munawwara, 116-17, 120-23, 134-35, 140-41.

101. See İ..D.H.., Kutu: 976, Gömlek: 77072 in the Republic of Turkey's Presidency State Archives.

102. 'Abd al-Ghaffar mentions these photographs in a letter to Snouck Hurgronje preserved in the Leiden University Libraries (Or. 18.097 S 32.6). For a translation of it, see Sui, "Pilgrimages to the Holy Sites," 58-59; and Sui, "Early Photography of the Holy Sites," 135.

103. The Bilder-Atlas contains a collotype of the Hamidiyye Barracks (\#4) that is identical with the albumen print in Album $90877\left(\#_{24}\right)$. Moreover, the tinted lithograph of the police station (\#6) in the Bilder-Atlas must be after a copy of the police station photograph in Album $90877\left(\#_{23}\right)$, as the figures in the latter suggest. In the inventory form attached to the inner cover of Album 90877, a certain Behçet from the photography workshop of the Fourth Imperial Army (Dördüncü Ordu-yı Hümāyūn Fotoğrafhānesi) is noted as the author of the album. This attribution is doubtful for the Mecca photographs, considering that the Fourth Imperial Army was based in Erzincan and the Mecca photographs might have been acquired by other means. Nevertheless, it is not yet possible to securely match these photographs with the oeuvres of Sadiq Bey, 'Abd al-Ghaffar, or an Ottoman photographer.

104. This panorama must be the first photograph in Sadiq Bey's portfolio. For different copies of this photograph, see 90770/3a-b in the Istanbul University Library, no. 21341924 in the Victoria and Albert Museum in London, and WR 12/o1 in the Reiss-Engelhorn Museum in Mannheim. The Istanbul and Mannheim copies were published in Dördüncü, The Yıldız Albums of Sultan Abdülhamid II, 78-79; and Wieczorek, Tellenbach, and Sui, To the Holy Lands, 125 .

105. See $90789 / 1$ in the Istanbul University Library and Or. 26.367/5 in the Leiden University Libraries. The Istanbul copy was published in Dördüncü, The Yıldız Albums of Sultan Abdülhamid II, 89. The Leiden copy is a photograph of a photograph.

106. Here, it should be noted that the authorship of some photographs is not always straightforward. Such uncertainty occurs between portrait photographs attributed to 'Abd alGhaffar and Snouck Hurgronje, and outdoor photographs attributed to 'Abd al-Ghaffar, Sadiq Bey, and another member of a later military committee. For instance, the lithograph of the Egyptian mahmal in the fifth folio of the Bilder-Atlas is argued to be after a photograph by Sadiq Bey, even though the original photograph in the Leiden University Libraries is signed by 'Abd al-Ghaffar (Or. 12.288 L/4). Arnoud Vrolijk suggests that the photograph was taken by the Egyptian army officer and passed on to the Meccan doctor based on the circular outline of the lens that is absent in the rest of Abd a-Ghaffar's photographs, the orderly setting of the mahmal composition that could be achieved by a higher authority, and the photographic reproduction of the same photograph in Sadiq Bey's Dalïl al-Hajj. Vrolijk, "An Early Photograph of the Egyptian Mahmal in Mecca," 209.

107. They are organized in the following manner: the Great Sharif of Mecca, Awn al-Rafiq; the Ottoman governor of the Hijaz, Osman Nuri Pasha; the guardian of the Kaba (from the Bani Shaiba family); distinguished merchants and Turkish officials in Mecca; male members of the Great Sharifs family; sayyids (descendants of the Prophet Muhammad) and members of the learned class in Mecca; and finally pilgrims in Mecca and Jidda. By placing the portraits in such an order, from the most elevated officials to ordinary pilgrims, Snouck Hurgronje evidently reflects on the social hierarchy in the Hijaz.

108. For a comparison, see the original kiswa fragment in Mols, Verlangen naar Mekka, 164-65, cat. 68.

109. In the Bilder-Atlas, photographs taken in Jidda can be differentiated from those taken in Mecca based on the props and the setting. For instance, the window, potted plants, and the textured irregular floor suggest that the photograph was taken in the courtyard of the Dutch consulate. In these photographs, pilgrims are often grouped standing, sitting, or crouching in their local outfits and sometimes holding papers that might be travel permits. In photographs from Mecca, one can often spot a stretched textile pinned to the floor to obtain a uniform background and a carpet or textile spread on the ground to hide the irregularities of the surface.

110. Similar ethnographic themes were emphasized in several other projects, such as the Elbise-i 'Osmanniyye or Les costumes populaires de la Turquie, a costume album published during the reign of Sultan Abdülaziz (r. 1861-76) for the World Exposition in Vienna in 1873. In the Elbise, the provinces of the Hijaz, Yemen, and Tripoli were studied in the same group and received their own introductory texts and a total of four photographs representing their costumes. Victor Marie de Launay and Osman Hamdi Bey, 1873 Yılında Türkiye'de Elbise-i 'Osmāniyye, trans. Erol Üyepazarcı (Istanbul: Sabancı Üniversitesi Yayınları, 1999), 437-39. See also Ahmet Ersoy, "A Sartorial Tribute to Late Tanzimat Ottomanism: The Elbise-i 'Oșmāniyye Album," Muqarnas 20 (2003): 187-207; and Erin Hyde Nolan, "You Are What You Wear: Ottoman Costume Portraits in the Elbise-i Osmaniyye," Ars Orientalis 47 (2017): 178-209.

111. For a study on Snouck Hurgronje's insights and zeal regarding the Dutch consul position in Jidda, see Jan Just Witkam, "Snouck Hurgronje's Consular Ambitions," in Scholarship between Europe and the Levant: Essays in Honour of Alastair Hamilton, ed. Jan Loop and Jill Kraye (Leiden: Brill, 2020), 349-73.

112. Some of these objects can be found in the Museum of Ethnology in Leiden. Luitgard Mols and Arnoud Vrolijk, Western Arabia in the Leiden Collections: Traces of a Colourful Past (Leiden: Leiden Publications, 2016), 161-77.

113. Snouck Hurgronje, Bilder aus Mekka, n.p.

114. The last three photographs in Bilder aus Mekka are different from the rest, which depict architecture, urban space, 
and the pilgrimage sites. Photographs in Bilder aus Mekka do not follow the systematic ethnographic approach of the Bilder-Atlas, since Snouck Hurgronje only compiled photographs taken by 'Abd al-Ghaffar. Snouck Hurgronje's detailed explanations accompanying these three ethnographic images, as opposed to his short descriptions of the photographs of Mecca, indicate their importance. One of these photographs, as Snouck Hurgronje explains, is of four figures and a camel: the camel of Sharif Yahya decorated with silver embroidery, his attendant holding the bridle, Sharif Yahya himself in his riding outfit, and two other sharifs (descendants of the Prophet Muhammad's grandson Hassan). Unlike the portraits taken in the courtyard of the Dutch consulate or the studio in Mecca, this photograph was taken outside in an arid landscape with hills in the background. The other two photographs are of a bridal throne (rikah) with and without the groom.

115. A copy this photograph can be found in the Republic of Turkey's Presidency State Archives (FTG.f., Kutu: 1749).

116. Selçuk Akşin Somel, “Osman Nuri Paşa'nın 17 Temmuz 1885 Tarihli Hicaz Raporu," Ankara Üniversitesi Dil ve TarihCoğrafya Fakültesi Tarih Bölümü Tarih Araştırmaları Dergisi 29 (1996): 9-11.

117. On wedding costumes, see Mols and Vrolijk, Western Arabia in the Leiden Collections, 140-41.

118. The caption translates as follows: "Ladies in the house and street costume, shot of Siegfried Langer." It partially explains the oddity of the photograph among the others in the Bilder-Atlas. The photograph was taken by the German traveler and researcher Siegfried Langer at the Dutch consulate in Jidda.

119. In Bilder aus Mekka, no captions are added; rather, Snouck Hurgronje provides a list of plates under which he explains every single photograph. Snouck Hurgronje, Bilder aus Mekka, n.p. See also Mols and Vrolijk, Western Arabia in the Leiden Collections, 140-41.

120. The Yıldız Albums, however, present the issue of gender from a different perspective and thus suggest alternative ways of viewing the "Orient." Zeynep Çelik suggests that new voices outside the Orientalist canon complicate the approach to arts and thus force one to think beyond reductionist codes. Zeynep Çelik, "Colonialism, Orientalism, and the Canon," Art Bulletin 78 (1996): 205.

121. Michelle L. Woodward, "Between Orientalist Clichés and Images of Modernization: Photographic Practice in the Late Ottoman Era," History of Photography 27 (2003): 364.

122. According to the painting's recent restoration report, there is no trace of an underdrawing or grid that Mi'marzade could have used to transfer his source images onto the canvas. Woltman, Homer, and de Ridder, "Fatih Mosque Painting Restored," 19-30.

123. The red caption in the upper left reads "Keepsake of Medina the Illuminated" (Medine-i Münevvere Yãdigārı). The red inscription in the upper middle of the postcard reads "ḥukūküül-țab`-ı maḥūz sene 1270 șāḥib-i imtiyāz Fizanlı Hadīd 'Abdurraḥman," noting the year 1270 (1853-54) for
Fizanlı Hadid Abdurrahman's right and privilege to print the original lithograph. It is important to note that the date might be specific to the permission, not to the print itself. This postcard was also published in Murat Kargill, Kutsal Yolculuk Hac: Kartpostallarla Hac Yolu / The Holy Journey Hajj: The Haij Route through Postcards (Istanbul: Denizler Kitabevi, 2014), 287.

124. George Webber, "Coding of Emil Pinkau Cards," The Postcard Album: Postcard Printer \& Publisher Research, accessed October 19, 2018, <http://www.tpa-project.info/ TPA_16_3_Pinkau.pdf $>$. According to Gökhun Yılmaz, the following postcard editors were working with Emil Pinkau \& co: Max Fruchtermann, M.B., J. Matalon, Joseph and Nessim Mitrani, L. Mouradian, and Hatchik Tcholakian. Gökhun Yılmaz, Osmanlı Dönemi Kartpostal Editörleri 18951923: Anadolu, Trakya, Istanbul / Ottoman Era Postcard Editors 1895-1923: Anatolia, Thrace, Istanbul (Istanbul: privately published, 2019), 26.

125. The black inscriptions in the lower right of both prints read "Ma'ārif-i 'Umūmiyye Nezāāret-i Celīlesinin 11 Zilḳa'de 315 tārīh ve 603/205 numaralı ruhșātnāmesiyle tersīim ve tabc olunmuşdur," noting the license date of the print.

126. The photograph (Or. $12.288 \mathrm{~L} / 16$ ) is in a folder of twentythree albumen prints, some of which are signed by 'Abd al-Ghaffar.

127. Before IRCICA moved to its new location in Cağaloğlu, these paintings hung in the Seyir Kiosk of the Ylldız Palace, used as the general directorate. The painter of this work might be Üsküdarlı Mahmud (d. 1917), who graduated from the Military School (Mekteb-i Harbiyye) in 1898. Nüzhet İslimyeli, Asker Ressamlar ve Ekoller (Ankara: Asker Ressamlar Sanat Derneği Yayınları, 1965), 71. I would like to thank Orhan Çolak for providing me with the photographs of these paintings.

128. So far, I have not been able to locate Sadiq Bey's photograph of Medina in Ottoman illustrated journals; however, his photograph of the Green Dome and 'Abd al-Ghaffar's photograph of the Ka'ba were published in Ma'tumant (Information). For instance, the Green Dome's photograph (90770/5a or \#11 in Sadiq Bey's portfolio) appeared in the Ma'ümät issues of 26 Safar 1314/25 Temmuz 1312 and 10 Dhu'l-Hijja 1315/19 Nisan 1314/May 1, 1898, while the Ka'ba photograph (90789/4 or \#1 in Bilder aus Mekka) appeared in the Ma'lūmāt issues of 1o Dhu'l-Hijja 1312/22 Mayıs 1311 and 11 Dhu'l-Hijja 1315/20 Nisan 1314/May 2, 1898.

129. For more information on the Dalä'il al-Khayrāt, see Sabiha Göloğlu, "Depicting the Islamic Holy Sites: Mecca, Medina, and Jerusalem in Late Ottoman Illustrated Prayer Books," in Proceedings of the 15th International Congress of Turkish Art, Naples, 14-16 September 2015, ed. Michele Bernardini, Alessandro Taddei, and Michael Douglas Sheridan (Ankara: Republic of Turkey Ministry of Culture and Tourism, 2018), 323-38; Hiba Abid, "Un concurrent du Coran en Occident musulman du XVe à l'aube du XVIII e siècle: Les Dalā'il al-Khayrāt d'al-Jazūlī (m. 869/1465)," Journal of Qur'anic 
Studies 19 (2017): 45-73; Frederike-Wiebke Daub, Formen und Funktionen des Layouts in arabischen Manuskripten anhand von Abschriften religiöser Texte: al-Būșīrīs Burda, al-Ǧazūlìs Dalāil und die Šifä' von Qā Harrassowitz Verlag, 2016); Nurul Iman Rusli, Heba Nayel Barakat, and Amira Saleh, eds., Dala'il al-Khayrat: Prayer Manuscripts from the $16^{\text {th }}-19^{\text {th }}$ Centuries (Kuala Lumpur: Islamic Arts Museum Malaysia, 2016); and Jan Just Witkam, Vroomheid en activisme in een islamitisch gebedenboek. De geschiedenis van de Dalā'il al-Khayrāt van al-Ḡazul̄̄ (Leiden: Legatum Warnerianum, 2002). A recent workshop on the Dalā'il al-Khayrāt at the Metropolitan Museum of Art in New York (May 17-18, 2019) focused on the popularity of the text and its regional traditions. For papers presented in this workshop, see the related special issue of the Journal of Islamic Manuscripts 12, no. 3-4 (2021).

130. For a catalogue description, see Witkam, Vroomheid en activisme in een islamitisch gebedenboek, 183.

131. Tığlı, "Sultan Ahmet Camii'ndeki Harem-i Şerif Tablosu," 114-19.

132. For $90789 / 1$ in the Istanbul University Library, see Dördüncü, The Yıldız Albums of Sultan Abdülhamid II, 89.

133. See Or. 26.367/5 in the Leiden University Libraries.

134. The caption on the slide reads "Zentrum der Moschee," whereas the caption in the Bilder-Atlas reads "Die Moschee." See SR $59 / 3$ in the Leiden University Libraries.

135. Judging by its irregular addition to the list of slides and the approximate date (ca.193os), the portrait of the king must have been added to the box much later.

136. For instance, the caption of the single slide in the Nasser D. Khalili Collection (ARC.PP 125) reads "Ansicht von Mekka" and its other label reads "Th. Benzinger/Lichtbilderverlag/ Stuttgart." For the box of five slides, see Sotheby's, Travel, Atlases, Maps, and Natural History, 17 November 2015 (London: Sotheby's, 2017), lot 120.

137. I refer to a postcard in the Khalili Collection (ARC.PC 472) that was previously published in Kargilı, Kutsal Yolculuk $H a c, 286$. The red caption in the upper left reads "Keepsake of Mecca the Blessed" (Mekke-i Mükerreme Yãdigārı). The red inscription in the upper middle of the postcard reads "ḥukūkü'l-țab'-ı maḥüz sene 1270 șạḥib-i imtiyāz Fizanlı Hadìd 'Abdurrahman," noting the year 1270 (1853-54) for Fizanlı Hadid Abdurrahman's right and privilege to print the original lithograph. It is important to note that the date is specific to the permission, not to the print itself.

138. For representations of objects from Mecca and Medina that had commemorative and other functions, see Remke Kruk and Frans Oort, "Hajj Murals in Dakhla Oasis (Egypt)," in Mols and Buitelaar, Hajj, 163-84; Luitgard Mols, "Souvenir, Testimony, and Device for Instruction: Late Nineteenthand Early Twentieth-Century Printed Hajj Certificates," in Mols and Buitelaar, Hajj, 185-212; Suraiya Faroqhi, "Keepsakes and Trade Goods from Seventeenth-Century Mecca," in Travel and Artisans in the Ottoman Empire: Employment and Mobility in the Early Modern Era (London: I.B. Tauris, 2014), 89-98; John Renard, "Picturing Holy Places: On the
Uses of Architectural Themes in Ornament and Icon," Religion and the Arts 5 (2001): 339-428; and Juan E. Campo, "Shrines and Talismans: Domestic Islam in the Pilgrimage Paintings of Egypt," Journal of the American Academy of Religion 55 (1987): 293-96.

139. For a brief article on prayer rugs depicting the Ka'ba, see Ayşen Aldoğan, "Kābe Tasvirli Osmanlı Seccadeleri," Antik Dekor 42 (1997): 162-64.

140. Here, I have revised the transliteration provided by Aldoğan. Even though I have not been able to read it due to the low resolution of the image provided in the article, the author states that the phrase "Long live our sultan" (Pādişāhımı z̧̧okyaşa) was inscribed on the upper left corner of the prayer rug. Ibid., 164.

141. Gülru Necipoğlu has shown that Ottoman architecture adhered to a specific decorum that shaped the building of mosques in the sixteenth century. Gülru Necipoğlu, The Age of Sinan: Architectural Culture in the Ottoman Empire (London: Reaktion Books, 2005), 20-23, 115-24.

142. For Mecca and Medina tiles, see Charlotte Maury, "Depictions of the Haramayn on Ottoman Tiles: Content and Context," in Porter and Saif, The Hajj: Collected Essays, 143-59; Sabih Erken, "Türk Çiniciliğinde Kabe Tasvirleri," Vakıflar 9 (1971): 297-320; Kurt Erdmann, "Ka'bah-Fliesen," Ars Orientalis 3 (1959): 192-97; and Richard Ettinghausen, "Die bildliche Darstellung der Ka'ba im islamischen Kulturkreis," Zeitschrift der Deutschen Morgenländischen Gesellschaft 12 (1934): 111-37. For late Ottoman wall paintings with images of the Haramayn, see Dilek Şener, "XVIII ve XIX. Yüzyıllarda Anadolu Duvar Resimleri" (PhD diss., Ankara University, 2011), 409-10. For a recent digital image of the Kaba projected on the mihrab wall of the Hacı Bayram Mosque's women's section, see Gruber, "Islamic Architecture on the Move," 248-49, fig. 5 .

143. Maury, "Depictions of the Haramayn on Ottoman Tiles," 151-54.

144. For more information about pilgrimage scrolls of different regions and periods, see Mounia Chekhab-Abudaya, Amélie Couvrat Desvergnes, and David J. Roxburgh, "Sayyid Yusuf's 1433 Pilgrimage Scroll (Ziyaratnama) in the Collection of the Museum of Islamic Art, Doha," Muqarnas 33 (2016): 345-407; Ulrich Marzolph, "From Mecca to Mashhad: The Narrative of an Illustrated Shici Pilgrimage Scroll from the Qajar Period," Muqarnas 31 (2014): 207-42; Luitgard Mols, "Souvenir, Testimony, and Device for Instruction," 185-212; Dominique Sourdel and Janine Sourdel-Thomine, Certificats de pèlerinage d'époque ayyoubide: Contribution à l'histoire de l'idéologie de l'islam au temps des croisades (Paris: L'académie des Inscriptions et Belles-Lettres, 2006); and Zeren Tanınd,, "Resimli Bir Hac Vekaletnamesi," Sanat Dünyamız 28 (1983): 2-6.

145. For a literary mention of the hanging of pilgrimage certificates in mosques, the authors refer to Jean Chardin's (d. 1713) travelogue based on Joseph Toussaint Reinaud's work (d. 1867). Şule Aksoy and Rachel Milstein, "A Collection 
of Thirteenth-Century Illustrated Hajj Certificates," in $M$. Uğur Derman Festschrift: Papers Presented on the Occasion of His Sixty-Fifth Birthday, ed. Irvin Cemil Schick (Istanbul: Sabancı University, 2001), 103-4n6.

146. David Roxburgh, "Pilgrimage City," in The City in the Islamic World, ed. Renata Holod, Attilio Petruccioli, and André Raymond (Leiden: Brill, 2008), 773.

147. Göloğlu, "Depicting the Holy," 226-69. See also Kathryn M. Rudy, Virtual Pilgrimages in the Convent: Imagining Jerusalem in the Late Middle Ages (Turnhout: Brepols, 2011), 171-95.

148. For photographic images that could transport armchair travelers to various locations, see Joan M. Schwartz, "The Geography Lesson: Photographs and the Construction of Imaginative Geographies," Journal of Historical Geography 22 (1996): 16, 20. For photographs of Mecca and Medina that could transport pious viewers to the holy sites, see Asani and Gavin, "Through the Lens of Mirza of Delhi," 18o-81.

149. This painting seems to be dated to $135^{2}$ (1936?); however, I have not been able to read the signature. Nişantaşı Müzayede, 31 Mayıs 2015 (Istanbul: Nişantaşı Müzayede, 2015), lot 705 .

150. For two similar levhas, see Malik Aksel, Türklerde Din̄ Resimler (Istanbul: Elif Yayınları, 1967), 150-51; and Haremeyn:Hac-Mukaddese Yolculuk / Haremeyn: Hajj-Journey to Holiness (Istanbul: İstanbul Büyükşehir Belediyesi, 2017), 164.

151. A similar bird calligram reads "O Hazret-i Bektaş-i Veli, may God reveal his mystery" (Ya Hażret-i Bekțaş-i Velì kaddesallähu sirrehu), but it is difficult to decipher and contextualize (Aksel, Türklerde Dinı̄ Resimler, 74). See also İvin Cemil Schick, "Hz. Ali ve Devesi Levhaları," in Deve Kitabı, ed. Emine Gürsoy Naskali and Erkan Demir (Istanbul: Babil Kitabevi, 2014), 34.

152. Göloğlu, "Depicting the Holy," 9o-98; Ahmad Khamehyar,
"Osmanlı Dönemi Resimli Dua Kitaplarında Kutsal Emanetlerin Tasvirleri," in Tasvir: Teorive Pratik Arasında İslam Görsel Kültürü, ed. Nicole Kançal-Ferrari and Ayşe Taşkent (Istanbul: Klasik, 2016), 407-17; and Christiane Gruber, "A Pious Cure-All: The Ottoman Illustrated Prayer Manual in the Lily Library," in The Islamic Manuscript Tradition: Ten Centuries of Book Arts in Indiana University Collections, ed. Christiane Gruber (Bloomington, IN: Indiana University Press, 2009), 133-34; and Alexandra Bain, "The En'am-1 Şerif: Sacred Text and Images in a Late Ottoman Prayer Book," Archivum Ottomanicum 19 (2001): 22732.

153. Horst Bredekamp, "The Picture Act: Tradition, Horizon, Philosophy," in Bildakt at the Warburg Institute, ed. Sabine Marienberg and Jürgen Trabant (Berlin: De Gruyter, 2014), 18-2o.

154. For the sitāra, see Sumiyo Okumura, "The Mamluk Kaaba Curtain in the Bursa Grand Mosque," Textile Society of America Symposium Proceedings, Paper 721, accessed October 19, 2018, <https://digitalcommons.unl.edu/ tsaconf $/ 721 />$.

155. There is also a piece of the black stone on the exterior façade of the tomb of Sultan Süleyman I in Istanbul and one in the Eski Camii in Edirne. For all these black stones, see Necipoğlu, Age of Sinan, 241, 336-37.

156. Sometimes architectural constraints do not permit the placement of objects precisely in the qibla direction, as in the Mecca tile in the Hekimoğlu Ali Paşa Mosque in Istanbul (Maury, "Depictions of the Haramayn on Ottoman Tiles," 152). In rare cases such as the wall paintings of the Masjid al-Haram and the Masjid al-Nabawi in the Shrine of Khawaja 'Abdullah Ansari near Herat, the images do not conform to the qibla decorum at all (Lisa Golombek, The Timurid Shrine at Gazur Gah [Toronto: Royal Ontario Museum, 1969], 68, 146, fig. 16). 